\title{
Stress repair mechanism activity explains inflammation and apoptosis
}

\author{
Lewis S. Coleman
}

Barnes Dental Surgery Center, Visalia, USA

Email: Lewis_coleman@yahoo.com

Received 28 June 2012; revised 28 July 2012; accepted 16 August 2012

\begin{abstract}
A review of modern evidence using Internet resources has identified the Stress Repair Mechanism (SRM) postulated by Hans Selye in 1951. SRM activity regulates thrombin generation to govern tissue maintenance, tissue repair, hemodynamic physiology, inflammation, and apoptosis. Thrombin utilizes ATP to energize coagulation, capillary hemostasis, chemotaxis, immune activity, mitosis, metabolism, angiogenesis, and the release of chemokines, cytokines, bradykinins, and prostaglandins that enable cell-tocell communications, promote perfusion, loosen cell connections, and sensitize nociceptors during tissue repair. The orchestration of these diverse activities by the SRM explains the disparate elements of the inflammation syndrome, including dolor (pain), rubor (redness), calor (heat), tumor (swelling), and Functio laesa (loss of function). Inflammation resolves as tissue repair nears completion and declining SRM activity restores thrombin to maintenance levels. As thrombin levels decline below a critical threshold, repair cells undergo apoptosis and clots disintegrate. Apoptosis shrinks granulation tissues to enable wound closure. Apoptosis also facilitates embryological development. Occult systemic SRM hyperactivity due to sepsis, surgery, trauma, chemicals, pain, fear, and emo-tional memories causes inflammatory effects that manifest as the fever, edema, malignancy, organ disruption, eclampsia, Multi-System Organ Failure (MSOF), Systemic Inflammatory Response Syndrome (SIRS), Adult Respiratory Distress Syndrome (ARDS), Disseminated Intravascular Coagulation (DIC) and other pathologies.
\end{abstract}

Keywords: Selye; Stress; Inflammation; Atherosclerosis; Tissue Repair; Hemodynamic

\section{INTRODUCTION}

Medicine remains an art based on experiment rather than a true science based on theory that enables predictably effective treatments. The nature of tissue repair is unknown. Inflammation, apoptosis, and embryological development remain mysterious. Hemodynamic physiology is customarily attributed to direct autonomic innervation that controls cardiac and arteriolar contractility, but this explanation is notoriously weak. Smooth muscle contraction is energy intensive, short-lived, and followed by obligatory vasodilation, so that it cannot explain sustained hypertension. Sustained increases in cardiac work cause congestive heart failure. These and other shortcomings in medical theory force physicians to base their treatments on symptoms rather than causes, so that treatments are often useless or even counterproductive.

Stress theory has represented the best hope for improved medical theory in recent times. In 1951, Hans Selye famously predicted that a single physiological mechanism maintains and repairs the vertebrate body. Selye's putative mechanism would theoretically enable a "Universal Theory of Medicine" that explains hemodynamic physiology, tissue repair, pathology, stress, and their relationships. It would revolutionize medical treatments and pharmaceutical development. Soon after Selye's prediction, the discovery of DNA inspired enormous excitement in medicine and biology. Since the DNA mechanism by itself does not explain how genetic information is converted into structural development, many expected that Selye's mechanism would function as a "companion mechanism" that works closely with DNA to enable embryological development. The companion mechanism would remain active to maintain mature structures and regulate hemodynamic physiology for the duration of life, while DNA becomes quiescent once embryological development is complete. These exciting ideas inspired an intense but futile international search for a testable mechanism that could confirm Selye's theory.

Stress researchers developed two important concepts to help identify Selye's mechanism. Capillary gate theory postulates a submicroscopic mechanism that effi- 
ciently controls capillary flow. It theoretically explains capillary hemostasis, hemodynamic physiology, and organ function. Tissue repair theory postulates a single mechanism that governs tissue repair. It theoretically explains the orderly and predictable sequence of events that occurs during tissue repair, including inflammation and apoptosis [1].

Stress research lasted more than 30 years and consumed hundreds of research careers, thousands of test animals, and millions of dollars. Unfortunately, no testable mechanism was found that explains tissue repair or hemodynamic physiology, let alone both. Furthermore, capillary gate theory and tissue repair theory seemed incompatible. Despite its promise, the frustrating failure to find a testable stress mechanism caused stress theory to fall into disrepute, and it has now been almost completely abandoned for more than 30 years. Prominent experts have pronounced that no single mechanism could possibly explain the bewildering multitude of stress and disease manifestations [2,3]. However, that turns out not to be the case.

Powerful scientific theories often appear long before their time. They must await the death of critics and the accumulation of supporting evidence before they are embraced, and the visionaries who contribute them seldom outlast their critics ${ }^{1}$. Nearly thirty years after Selye's death, fresh evidence has finally enabled the first description of the long sought "stress repair mechanism" (SRM) that explains stress theory and enables it to be tested and verified (Figure 1) [4]. The SRM was identified after compelling new information about coagulation factor VIII inspired an extensive review of scientific literature using Internet resources [5]. PubMed provided the primary source of published medical research reports. Computer search techniques made it possible to efficiently evaluate thousands of research abstracts to identify pertinent papers, and obtain full copies via email. Sophisticated "Endnote" software ${ }^{2}$ facilitated the management of hundreds of essential references. The distinctive physical and enzymatic properties of factor VIII served as a "Rosetta Stone" that deciphered SRM characteristics and yielded a fresh explanation for coagulation [6] that was soon followed by explanations of atherosclerosis $[7,8]$, capillary gate theory $[9,10]$, and tissue repair theory [11,12]. Finally, all of these seemingly disparate mechanisms were comprehended as elements of the SRM [4].

The SRM exceeds the expectations of earlier stress researchers. As they anticipated, it explains both hemodynamic physiology and tissue repair, and it enables Selye's Universal Theory of Medicine that explains physicology, pathology, stress, and their relationships. In addi-

\footnotetext{
${ }^{1}$ http://en.wikipedia.org/wiki/Alfred_Wegener

2http://www.endnote.com/enhome.asp
}

tion, it provides a new theory of anesthesia, analgesia, allostasis, and surgical stress [13]. Its appearance explains the Cambrian Explosion. It provides unexpected insights to vertebrate cell biology, embryology, evolution, anatomy, apoptosis, behavior, intelligence, and taxonomy that will be detailed in a future publication. It explains the hitherto mysterious nature of inflammation and apoptosis and their role in the tissue repair process, which is the subject of this paper.

It retrospect, it is not surprising that the SRM eluded detection until now. It is complex and counterintuitive, and it conflicts with entrenched medical beliefs, practices, and assumptions. In retrospect, the previous generation of stress researchers was amazingly insightful, and their capillary gate and tissue repair theories paved the path to SRM discovery. The "coagulation cascade" concept that appeared in their time was analogous to the SRM, but critical information necessary to clarify the relationships of coagulation enzymes to tissue repair was unavailable until recently. Apoptosis was generally unknown before 1972 [14]. The dual autonomic innervation of the vascular endothelium was unclear [15]. Thrombin was regarded as a "coagulation enzyme" that was similar to other enzymes in the coagulation cascade. The chimeric nature of Factor VIII had yet to be clarified [5]. "Nitrergic Neurogenic Vasodilation” was unknown [16]. Chemokines and cytokines were obscure [17]. Chemical tests could not distinguish the physical properties of fibrinogen, soluble fibrin, and insoluble fibrin. These and other important elements of SRM operation have been clarified during the 30 years since stress theory was abandoned, and this fresh information has finally enabled the first crude description of the SRM.

\section{THE STRESS REPAIR MECHANISM}

Even though compelling evidence suggests an intimate relationship between coagulation and tissue repair, medical education has traditionally treated hemostasis as an independent phenomenon whose sole purpose is to stem blood loss. Researchers and clinicians may therefore be surprised to learn that coagulation is but one manifestation of the cohesive SRM mechanism that explains tissue repair, hemodynamic physiology, pathology, and stress. Detailed and fully referenced descriptions of the SRM and its medical effects have already been published [4, $13]$ and are available from the author's website ${ }^{3}$.

The SRM consists of the autonomic nervous system, the vascular endothelium, and the enzymatic interaction of blood-borne hepatic enzyme Factors VII, VIII, IX, and $\mathrm{X}$ that generates thrombin, soluble fibrin, and insoluble fibrin. The effects of these three products explain all SRM manifestations, including inflammation and apoptosis.

\footnotetext{
${ }^{3}$ www.stressmechanism.com
} 


\section{COGNITIVE PATHWAY}

Cerebral ....-Visual, Olfactory

Cortex

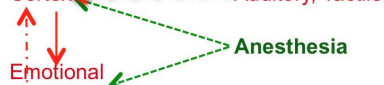

Emotional _......... Anesthesia

Mechanisms

i

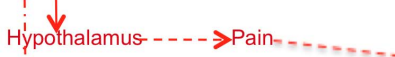

i

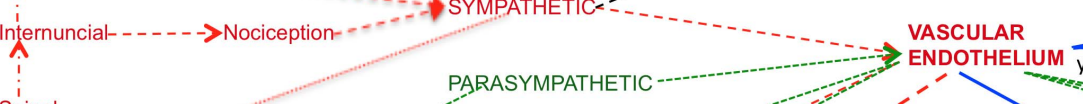

Spinal

Cord

Péripheral Analgesia

Nerves

个

Peripheral

Receptors

$\hat{i}$

Sensory

Stressors

SPINAL PATHWAY
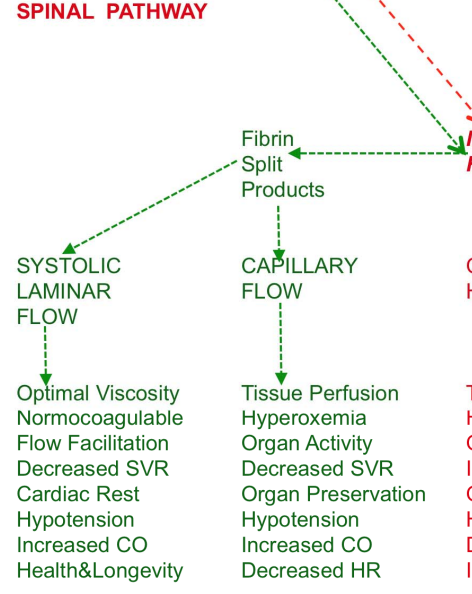

CAPILLARY GATE COMPONENT

(Intrinsic Pathway)

Stressful Stimuli

Intravascular

Intravascular

(C)

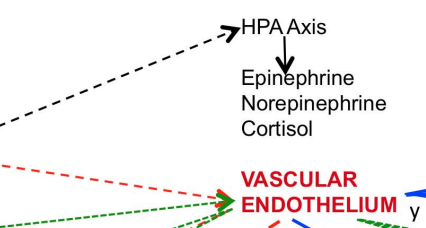

$\begin{array}{ll}\text { Nitric } & \text { Thrombin } \\ \text { Oxide } & \text { Amplification }\end{array}$

Factor IX

FACTOR

\section{The Stress Repair Mechanism (SRM)}

TISSUE REPAIR COMPONENT

(Extrinsic Pathway)

\section{Stressful Forces}

Extravascular

Tissue Disruption Burns

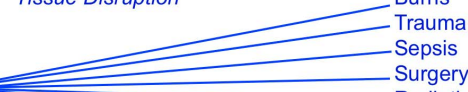

Radiation

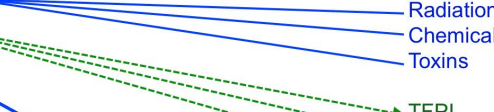

Insulinn

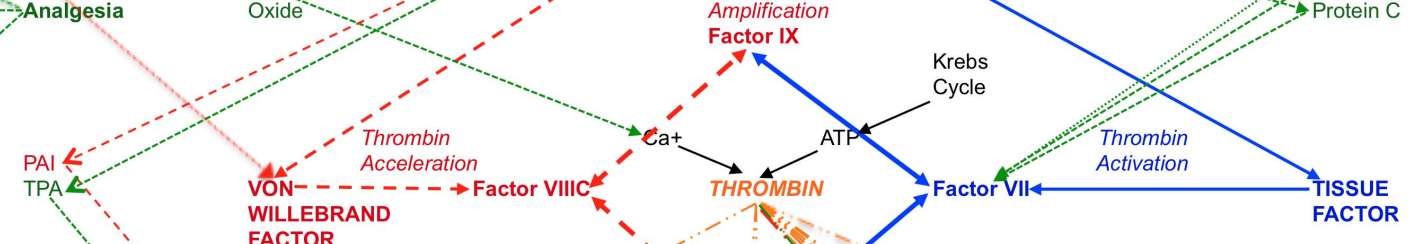

\begin{tabular}{cc}
\hline Term & Meaning \\
\hline TFPI & Tissue Factor Pathway Inhibitor \\
ATIII & Stoichiometric ATIII \\
ATP & Adenosine Tri-Phosphate \\
SVR & Systemic vascular resistance \\
CO & Cardiac output \\
HR & Heart rate \\
DIC & Disseminated Intravascular Coagulation \\
HAPE & High-Altitude Pulmonary Edema \\
ARDS & Adult Respiratory Distress Syndrome \\
MSOF & Multi-System Organ Failure \\
ARF & Acute Renal Failure \\
TPA & Tissue Plasminogen Activator \\
PAI & Plasminogen Activator Inhibitor \\
\hline
\end{tabular}

Figure 1. The Stress Repair Mechanism (SRM). The SRM appears complex, but its underlying structure is simple and symmetrical. Arrows represent the influence (direct and indirect) that one biological function or reaction brings to bear on another. The SRM is analogous to the older "coagulation cascade" concept, but it combines more recent research information with capillary gate theory and tissue repair theory to produce a cohesive explanation of capillary hemostasis, tissue repair, physiology, and pathology as well as coagulation. The capillary gate component corresponds to the intrinsic pathway of the coagulation cascade. The tissue repair component corresponds to the extrinsic pathway of the coagulation cascade. Both the SRM and the coagulation cascade generate thrombin, and convert fibrinogen to soluble fibrin and thence to insoluble fibrin. 
Thrombin is the "Universal Enzyme of Extracellular Energy Transduction." Though it is conventionally regarded as a "coagulation enzyme," it energizes both hemostasis and tissue repair. It also energizes activity that is not directly related to SRM operation, such as the complement cascade and gelsolin [18,19]. It transforms ATP energy into both cell and enzyme activities [20-32]. It affects all cell types thus far tested via their protease activated receptors (PAR), which vary in type and number according to individual cell types [31,33-42]. It increases intracellular Calcium levels and mitochondrial activity via PAR-1 receptors [21,31,37,43-48]. Its activity requires $\mathrm{Ca}+$, and parathyroid glands regulate extracellular $\mathrm{Ca}+$ to optimize its activity [48-62]. $\mathrm{Mg}+$ competitively inhibits $\mathrm{Ca}+$ and mitigates thrombin activity $[46,49,58,63-78]$.

All cells thus far tested possess PAR (thrombin) receptors that are present in various combinations that are characteristic of specific cell types, and these combinations determine how individual cell types react to thrombin $[79,80]$. PAR (thrombin) receptors are over-expressed during both malignancy and normal tissue repair [25,81].

The SRM continuously generates thrombin in all tissues to energize tissue maintenance [82,83]. It accelerates thrombin generation to energize hemostasis immediately after injury [84]. It then maintains lesser thrombin elevations to energize tissue repair [79]. As healing nears completion, it returns thrombin to maintenance levels, causing clot disintegration and apoptosis of repair cells that facilitates wound closure $[33,38]$. Thrombin energizes and orchestrates all elements of tissue maintenance and repair including the following:

- Chemotaxis of platelets, osteocytes, white blood cells, and other tissue repair cells $[53,79,80,85]$

- Mitosis $[42,53,82,86,87]$

- Metabolism [53]

- Hypertrophy [53,80,88-91]

- Angiogenesis $[21,45,92]$

- Platelet activation, chemotaxis, and thromboxane release [20,93-96]

- Proliferation, spreading and gap formation in the vascular endothelium [47,97]

- Release of chemokines, cytokines, interleukins, bradykinins, caspases, and prostaglandins [35,85,90,98106]

- Production of bone, muscle, collagen and immune activity by osteocytes, myocytes, fibroblasts, and immune cells $[17,28,33,43,51,80,86,89,91,97,107-116]$

- Conversion of fibrinogen to soluble fibrin [56] that facilitates tissue repair

- Conversion of fibrillar soluble fibrin to three-dimensional insoluble fibrin [55,84,117-125] that enables hemostasis and regulates tissue repair and hemodynamic physiology
- Stabilization of insoluble fibrin via "Thrombin-Activated Fibrinolysis Inhibitor” (TAFI) [122,126-129]

- Inflammation, which dissolves the "basement membrane" that binds cells in tight formation with one another and with the Vascular Endothelium to facilitate chemotaxis [37,51]

- Proliferation of astrocytes and glial cells in brain tissue $[42,87]$.

- Activation of gelsolin that neutralizes Actin [18]

- Complement activation that attacks foreign antigens [19]

- T-cell activation independent of an immune response $[39,109]$

- Blast transformation in lymphocytes

- Increased macrophage phagocytic activity [39,45,48, 92,109,113,130]

- Activation of plasma (immune) cells and neutrophils $[113,124,131]$

- Release of "Tumor Necrosis Factor" from microglial cells [132]

- Tumor growth, malignancy, and fibrosis [29,33,34,38, $107,108,112,133,134]$

- Inhibits apoptosis $[31,34,40,41,135,136]$

- Intracellular gap formation in the vascular endothelium that increases permeability [47]

- Defects in Factors VII, X and Tissue Factor that disrupt thrombin generation necessary for embryological development and tissue repair are generally lethal [137]

- Embryological development, tissue maintenance, wound healing [24,44,82,83,138]

Thrombin energizes the conversion of fibrinogen to soluble fibrin, and then energizes the conversion of soluble fibrin to insoluble fibrin (see below). Older studies have confused fibrinogen, soluble fibrin, and insoluble fibrin, because they are nearly identical chemically [125, 139-142]. Their fluctuating equilibrium determines blood viscosity and coagulability (see "The capillary gate component” below).

Fibrinogen is a structurally complex protein molecule that exists in more than one form. It is the precursor of both soluble and insoluble fibrin. The liver produces and releases fibrinogen into the blood at steady rates. It cannot escape the intact vasculature. It is not directly involved in either tissue repair or hemostasis, but fibrinogen depletion causes defective insoluble fibrin production $[117,143]$. Fibrinogen consists of alpha, beta and gamma subunits that are connected by disulfide bonds [125]. Thrombin disrupts the disulfide bonds and causes the alpha, beta, and gamma fibrinogen subunits to polymerize into fibrillar (two-dimensional) strands of "soluble fibrin" $[47,56,123]$.

Soluble fibrin is the "Universal Protein of Tissue Repair." It is the precursor of insoluble fibrin, but it has no 
direct effect on blood viscosity and coagulability. It is the substance of pus, scabs, mucus, exudates, renal casts, and hyaline deposits $[144,145]$. Thrombin-generated soluble fibrin escapes from the vascular system through thrombininduced inflammatory gaps in the vascular endothelium into thrombin-inflamed extravascular tissues to form a structural matrix that facilitates the formation of granulation tissue that fills wound cavities $[28,47,56,86,122,124$, 144]. Excessive soluble fibrin generation causes tissue edema and disrupts organ function. For example, soluble fibrin causes proteinuria and hyaline casts. It disrupts pulmonary function by flooding alveoli in pneumonia and influenza, and narrowing airway passages in asthma [139,144,146,147]. Soluble fibrin deposits promote collagen production, fibrosis, sclerosis, adhesions, and scar formation [116,140,141,148-159]. For example, peritoneal soluble fibrin deposits produce peritoneal adhesions after surgery and infection, and alveolar soluble fibrin evolves into pulmonary fibrosis in the aftermath of ARDS, chronic asthma, and prolonged pulmonary infection. Thrombin inhibition mitigates soluble fibrin generation and collagen production [108], but most anticoagulants have minimal effect on soluble fibrin deposits and collagen scars once they have formed [160].

Insoluble fibrin is the "Universal Polymer of Hemostasis". It cannot escape the intact vascular system. It binds red cells and platelets together, and this produces several seemingly unrelated effects. It increases blood viscosity and coagulability, accelerates atherosclerosis, activates capillary hemostasis, and forms viscoelastic clots that stem blood loss and then regulate tissue repair [123,161-170]. The generation and disintegration of insoluble fibrin explains viscoelastic clot formation, capillary hemostasis, hemodynamic physiology, organ regulation, tissue repair regulation, atherosclerosis acceleration, infarction, and the effects of anticoagulants and "vasoactive" drugs [171].

The conversion of soluble fibrin to insoluble fibrin occurs in a series of complex enzymatic interactions. Factor VIII accelerates thrombin generation to energize its enzymatic conversion of Factor X to Factor XIII [163, 168,169]. Factor XIII adds plasminogen and fibronectin cross-links to fibrillar soluble fibrin to generate threedimensional insoluble fibrin that spontaneously polymerizes into strands that bind red cells and platelets together [165,170,172]. The plasminogen cross-links spontaneously deteriorate into plasmin that disintegrates insoluble fibrin into inert fibrin split products (FSP, or d-Dimer) unless plasminogen is continuously stabilized by thrombin via Thrombin Activated Fibrinolysis Inhibitor (TAFI) [122,126-129]. Parasympathetic Nervous System (PNS) activity stimulates the release of nitric oxide, which binds avidly to $\mathrm{Ca}+$, inactivates thrombin, and accelerates the disintegration of insoluble fibrin [49]. The ef- fects of insoluble fibrin are thus readily reversible, and this explains the fluctuations of blood viscosity, tissue perfusion, and organ regulation in accord with autonomic balance.

Hemophilia and von Willebrand Disease Coagulopathies illustrate the difference between soluble fibrin and insoluble fibrin. Both conditions paralyze Factor VIII, which impairs the ability to convert soluble fibrin to insoluble fibrin for hemostasis. Afflicted patients retain the normal ability to generate soluble fibrin to repair tissues and produce pus, scabs, exudates, soluble fibrin deposits, fibrosis, scars, and adhesions [173,174]. Like normal patients, they produce excessive quantities of soluble fibrin in accord with pneumonia, influenza, ARDS, MOFS, asthma, and eclampsia [146,147,155-157,175]. However, their inability to produce Factor VIII in normal quality and/or quantity inhibits their ability to accelerate thrombin generation to activate platelets, energize the enzymatic conversion of soluble fibrin to insoluble fibrin, and stabilize the insoluble fibrin molecule via "ThrombinActivated Fibrinolysis Inhibitor” (TAFI) [93,126,170, 176-182]. This explains why they exhibit abnormally low blood viscosity and coagulability, retarded atherosclerosis, and reduced incidence of heart disease, as well as defective coagulation and capillary hemostasis [183-185]. Defects or deficiencies in Factor XIII also disrupt the conversion of soluble fibrin to insoluble fibrin by inhibiting the installation of plasminogen and fibronectin cross-links in the insoluble fibrin structure, but these Coagulopathies do not impair thrombin generation and platelet activation and are usually less severe [186-188].

Insoluble fibrin elevations cause increased viscosity and coagulability that pre-disposes to Disseminated Intravascular Coagulation (DIC), thrombophlebitis, pulmonary embolus, and accelerated atherosclerosis [189-194]. Insoluble fibrin generation also closes the capillary gate and disrupts perfusion and oxygenation in organs and tissues (see "Capillary Gate Component” below). This causes stroke [195,196], mental disturbances [197,198], myocardial infarction [195,199-202], renal dysfunction [145], bowel infarction, bowel ileus, and increased vascular resistance.

\section{THE DYNAMIC ENZYMATIC INTERACTION OF FACTORS VII, VIII, IX, AND X}

The interaction of hepatic Factors VII, VIII, IX, and X generates thrombin, soluble fibrin, and insoluble fibrin. Tissue factor activates Factor VII to initiate the interacttion [54,121,158,203-213]. Factor VII slowly penetrates the vascular endothelium to enter extravascular tissues, where tissue factor activates it to generate small amounts of thrombin sufficient to energize tissue maintenance [83, 214], but insufficient for hemostasis or tissue repair 
[121]. In the immediate aftermath of injury, Factor VIII interacts with Factors VII, IX, X and tissue factor to $a c$ celerate thrombin generation to very high levels necessary to energize insoluble fibrin production for coagulation [123,162-170]. The viscoelastic clot then regulates contact between blood enzymes and damaged tissues. It is impermeable to Factor VIII, but it allows Factors VII, IX and $\mathrm{X}$ to enter damaged tissues, where Factors IX and $\mathrm{X}$ interact with Factor VII and tissue factor to amplify thrombin generation to levels sufficient to energize cellular repair activities [121,215].

The priority of tissue development, maintenance, and repair is illustrated by teratogenic and potentially lethal anticoagulants and defects that affect Factors VII, X and tissue factor $[32,52,82,83,108,216,217]$. Defects in hemostasis Factors VIII, IX and XIII are non-teratogenic and survivable [173]. Heparin does not disturb tissue maintenance and is non-teratogenic because it inhibits only Factor VIII.

\section{THE CENTRAL ROLE OF THE VASCULAR ENDOTHELIUM}

The vascular endothelium is a ubiquitous, diaphanous, selectively permeable layer of cells, one cell thick, that lines all blood vessels and is the sole constituent of capillary walls. It controls the dynamic interaction of enzymatic Factors VII, VIII, IX and X. The vascular endothelium secretes tissue factor into extravascular tissues and then insulates it from the Factor VII flowing freely in blood, so that tissue damage exposes tissue factor to blood-borne Factor VII and initiates tissue repair component activity (see "Tissue Repair Component” below) [203,210,212,218-221].

The vascular endothelium also functions as a neuroendocrine organ that releases nitric oxide hormone and von Willebrand Factor hormone into blood in accord with autonomic balance to regulate the capillary gate component (see "Capillary Gate Component" below) [15, 222-226]. Endothelial cells respond to their immediate surroundings and communicate with one another via electrical signals. Endothelial cells also produce fibronectin [165], tissue factor pathway inhibitor (TFPI) [220], protein $C$ [227], and tissue plasminogen activator (TPA) [144,228].

\section{THE SRM SUB-COMPONENTS}

The SRM consists of two semi-independent sub-components. The tissue repair component regulates Factor VII activity to maintain and repair extravascular tissues. The capillary gate component regulates Factor VIII activity to govern hemodynamic physiology. These two sub-components share the enzymatic interaction of Factors VII, VIII, IX, and X, so that the activity of each ex- aggerates that of the other. This enables the SRM to generate positive feedback and focus its powerful effects to repair damaged tissues. It also explains the bewildering variety of SRM manifestations in health and disease.

\section{THE CAPILLARY GATE COMPONENT}

The capillary gate component consists of Factors VII, VIIIC, IX and X, the autonomic nervous system, the vascular endothelium, von Willebrand Factor, and nitric oxide. It generates and disintegrates insoluble fibrin in accord with autonomic balance to simultaneously govern a capillary gate mechanism (see page 9) that regulates tissue perfusion, capillary hemostasis, and organ function and a turbulence mechanism (see page 10) that regulates turbulent viscosity in arterial blood flow [222,229-231]. The capillary gate component explains why von Willebrand Factor, Factor VIII, insoluble fibrin, d-Dimer (Fibrin Split Products), blood viscosity, blood coagulability, blood pressure, cardiac output, heart rate, capillary hemostasis, tissue perfusion, tissue oxygenation, atherosclerosis, and organ function all fluctuate in accord with autonomic balance [15,222,231-246]. Its acute hyperactivation causes infarction, pulmonary embolus, thrombophlebitis, and high altitude pulmonary edema (HAPE) [189,190,195,199,247-266]. Its chronic hyperactivation accelerates atherosclerosis and capillary senescence that causes diabetes, hypertension, and congestive heart failure [225,231,232,257,267-279].

The Factor VIII complex links the sympathetic nervous system to the enzymatic interaction of Factors VII, VIIIC, $I X$ and $X$. Factor VIII consists of von Willebrand Factor produced by the vascular endothelium and Factor VIIIC produced by the liver. These bind together to circulate and exert their effects in concert. Sympathetic nervous system activity releases von Willebrand Factor hormone from the vascular endothelium to stabilize enzymatic Factor VIIIC and thereby regulate the activity and halflife of Factor VIII. Factor VIII then interacts with Factors VII, IX and $\mathrm{X}$ to accelerate thrombin generation to energize its conversion of Factor X to Factor XIII. Factor XIII adds "cross-links" of fibronectin and plasminogen to soluble fibrin to generate insoluble fibrin in capillaries and flowing blood [224,280-286]. Continued Factor VIII activity inhibits the spontaneous disintegration of insoluble fibrin into inert fibrin split products via thrombin activated fibrinolysis inhibitor (TAFI) [118,126,170,179, 234].

Parasympathetic nervous system activity disintegrates insoluble fibrin by releasing nitric oxide from the vascular endothelium. Nitric oxide is a ubiquitous gaseous signaling molecule that binds avidly to $\mathrm{Ca}+$, which inactivates thrombin, and thereby accelerates the spontaneous disintegration of insoluble fibrin [16,226,246,287-296]. 
Capillary gate component operation requires the continuous "leakage" of tissue factor from extravascular tissues into blood circulation to activate Factor VII, without which Factors VIII, IX and X remain inert. The vascular endothelium releases Stoichiometric ATIII, tissue factor pathway inhibitor (TFPI), and protein C hormones into blood to quench excessive Factor VII activity lest Factors VIII, IX and X interact with activated Factor VII to harmfully exaggerate thrombin generation in flowing blood [121,129,201,207,212,215,220,227,297301].

\section{THE CAPILLARY GATE MECHANISM}

Capillary perfusion is the essence of hemodynamic physiology. Athletic conditioning induces angiogenesis that enhances tissue perfusion and oxygenation, mitigates flow resistance, reduces blood pressure, and enhances ejection fraction, which slows heart rate via the Starling mechanism [24,270,302-317]. Allostatic load accelerates capillary senescence [318-320] that increases vascular resistance, impairs tissue and organ perfusion, inhibits glucose uptake, and causes diabetes and essential hypertension [142,192,231,232,267,273,276,277,279,321-327].

The capillary gate is a sub-microscopic, molecular mechanism that governs capillary flow, tissue perfusion, organ function, and capillary hemostasis-despite the absence of contractile musculature in capillaries. [15,254, $288,289,328,329]$ It operates efficiently, because capillary flow, pressure, and turbulence are minimal, and capillary surface area is greater than that of all other vessels combined. The capillary gate explains hemodynamic physiology and "vasoactive" drug effects in terms of fibrinogenesis and fibrinolysis (the generation and disintergration of insoluble fibrin) as opposed to "vasoconstriction," "vasodilation," and "stiffness" of muscular arterioles that become rapidly exhausted [66,171,229, 236,237, 242,251,254,280,330-334].

Sympathetic nervous system activity "closes" the capillary gate by causing the vascular endothelium cells of the capillary walls to release von Willebrand Factor [278, 282,283,285,286]. This release activates Factor VIIIC, which converts fibrinogen and fibronectin at adjacent binding sites into polymerizing strands of insoluble fibrin that bind to passing red cells and halt capillary flow [161, 165,186,273,335,336].

Nitrergic neurogenic vasodilation “opens" the capillary gate by releasing nitric oxide from the vascular endothelium in visceral organs, including eye, brain, lung, GI tract, urinary tract, and pancreas via direct parasympathetic innervation [16,226,246,287-290,337]. Parasympathetic stimulation also releases insulin, which indirectly mobilizes nitric oxide in the capillaries of skeletal muscle and other peripheral tissues where parasympathetic innervation is absent [331,338-348]. This explains why insulin prolongs bleeding time, reduces systemic vascular resistance, increases cardiac index, aggravates angina, and counteracts "vasopressor" (fibrinogenic) drugs [307,314,315,332,343,349-352]; why allostatic load inhibits insulin effects [353]; and why diabetes and hypertension are closely-related [225,231,232,268-271,273, 276-279,315-317,321-323,348,354-363].

The vascular endothelium additionally regulates capillary flow via TPA (tissue plasminogen activator) that disintegrates insoluble fibrin, and its rapid inhibitor, plasminogen activator inhibitor (PAI-1) [187,228,364,365]. Astrocytes proliferate when exposed to thrombin and release TPA to ensure brain perfusion [87,228]. Their anticoagulant effects necessitate abundant tissue factor, which explains the exaggerated morbidity of brain injury [107,140,210].

Coagulopathies reveal capillary gate characteristics. Capillary structural integrity requires von Willebrand Factor, so that chronic von Willebrand Factor deficiencies cause flow-related capillary damage called angiodysplasia [366-374]. Sudden von Willebrand Factor destruction disrupts capillary gate structure, causing anaphylaxis (angioneurotic edema), wherein vascular resistance and blood pressure drop sharply as blood shifts from larger vessels into capillaries, causing lethal airway edema, while coagulation enzymes and cardiac output remain unaffected [375-377]. Defective VIIIC (true hemophilia) paralyzes capillary gate regulation, causing exercise intolerance, but capillary gate structure and anaphylaxis susceptibility remain intact [378-380].

\section{THE TURBULENCE MECHANISM}

Red cell mass exceeds oxygen requirements, and hemoglobin encapsulation does not enhance oxygen delivery. However, the physical characteristics of red cells alter blood turbulence, and thereby beneficially affect blood viscosity, coagulability, atherosclerosis, and hemodynamic efficiency [381-385].

In pipes, turbulence causes viscosity (flow resistance) to increase exponentially with velocity in "Newtonian" fluids such as water and oil (Figure 2) [386]. Mammalian blood, however, is a "non-Newtonian" fluid that exhibits exponential declines in viscosity with increasing velocity. This is because bi-concave mammalian red cells spontaneously form highly efficient, self-organizing "aggregate” flow structures that suppress systolic turbulence to optimize blood acceleration, cardiac output, and peak end-systolic velocity [292,387-393]. Mammalian arterial blood flow during systolic ejection might thus be compared to electrical "superconductivity". The resulting hemodynamic efficiency explains the mammalian heart accelerates blood from 0 to $125 \mathrm{~cm} / \mathrm{s}$ in a tenth of a second (Figure 3) and why the hearts of both elephant and 


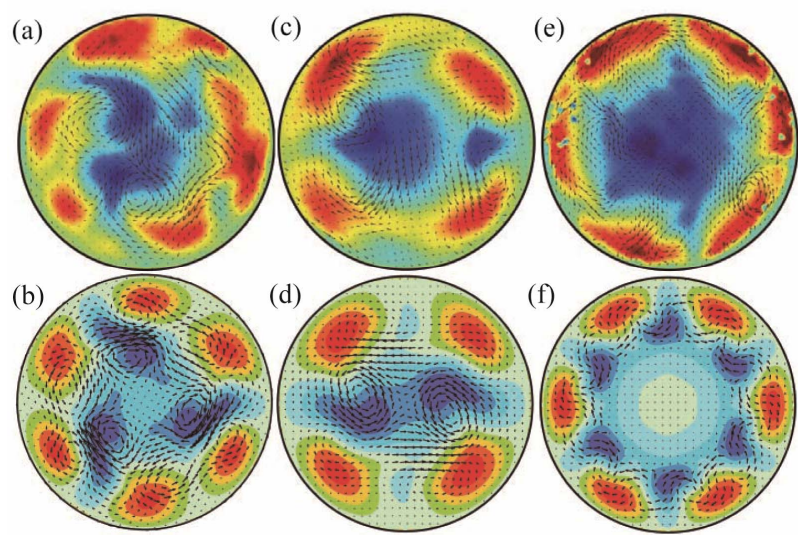

Figure 2. Newtonian pipe flow turbulence [386] turbulent forward flow appears as fast-moving "jet streams" (shown in red) that form along the inner walls of pipes and force slow-moving fluid to the center, where it moves backward (shown in blue), causing increased viscosity (flow resistance). (a), (c) and (e) are laser photographs that show "fast (a), faster (c) and fastest (e)" flow acceleration that produce "small (a), medium (c) and large (e)" increases in turbulent intensity. (b), (d) and F are computer simulations that predicted the experimental re- sults shown by (a), (c) and (e). Similar arterial turbulence dur- ing diastole mobilizes particulate deposits from arterial walls to prevent atherosclerosis. It also generates lateral forces that press on the inner walls of the vessel, which explains blood pressure and the palpable pulse.

mouse weigh only $0.6 \%$ of their body weight [394]. Diastolic deceleration disrupts the aggregates, and suddenly converts their kinetic energy into Newtonian turbulence that dissipates in a traveling pulse wave. The pulse wave periodically increases viscosity, halts flow, generates turbulent mixing that inhibits coagulation and atherosclerosis, and induces turbulent lateral forces that explain blood pressure and the palpable pulse [395,396].

Diastolic turbulence is inversely related to red cell mass. Polycythemia accelerates atherosclerosis and increases coagulability. Anemia progressively retards atherosclerosis and paralyses coagulation [176,397-403].

Oil must flow through a pipeline at high rates to generate enough turbulence to prevent sludge deposits [404]. Similarly, pulsatile arterial flow operates at the threshold of peak diastolic turbulence to prevent atherosclerosis. The vascular endothelium adjusts arterial diameter via neuromuscular control to optimize diastolic turbulent mixing, which mobilizes particulate deposits from arterial walls [236,405-407]. Without adequate turbulence, deposits form on the inner walls of arteries, and this activates the tissue repair component, causing thrombin and soluble fibrin generation, inflammation, tissue factor accumulation, fibrosis, and cholesterol trapping that forms atherosclerotic plaque [196,221,222,327,408-416].

The washing machine demonstrates how shear stress induces turbulence, and how viscosity exponentially inhibits turbulence even though it has no effect on shear
Ingzability in Artcrial Blood Plow 64

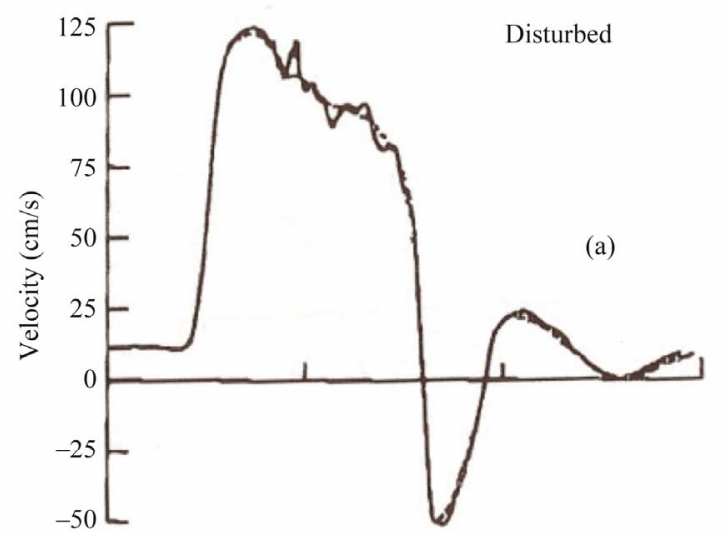

(b)
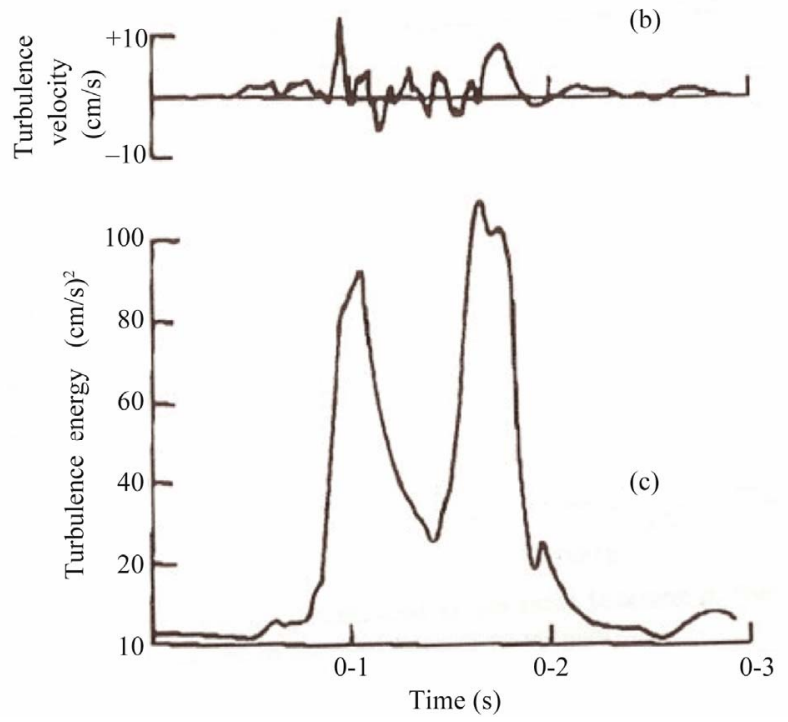

Figure 3. Turbulence and velocity in pulsatile blood flow in a dog. Mammalian red blood cells spontaneously form aggregates that suppress turbulence during systole to enable rapid and efficient blood acceleration. Diastolic deceleration disrupts the aggregates and converts laminar systolic flow into diastolic turbulence that halts net forward flow [395]. In humans, the brief flow reversal in the distal aorta inhibits turbulent cleansing and accelerates atherosclerosis relative to the proximal aorta [408].

stress. The rotor mechanism of the washing machine corresponds to the heart. The mixture of soap, water, and dirty clothes corresponds to blood. Like the heart, the rotor mechanism of the washing machine generates consistent work with each cycle. The force induced by the rotor corresponds to shear stress. Each times the rotor changes direction, it causes a burst of turbulent mixing that exponentially increases contact between soap, clothes, dirt, and water to enhance the ability of soap to clean clothes. The clothing load corresponds to blood viscosity. With reasonable clothing loads, turbulent mixing is optimized, and cleaning proceeds efficiently. If the 
machine is overloaded, the rotor energy is shifted in favor of turbulent lateral forces at the expense of turbulent mixing, and the clothes are not cleaned properly. Similarly, increased blood viscosity alters diastolic pulsatile blood turbulence in favor of turbulent lateral forces that increase blood pressure at the expense of turbulent mixing forces that inhibit atherosclerosis.

Atherosclerosis begins on the greater curvatures of arteries, where shear stress and systolic velocity decline and turbulence decreases exponentially [405-407,417421]. Diastolic turbulence increases exponentially with end-systolic velocity. Exercise increases cardiac contractility, elevates peak end-systolic velocity, exaggerates diastolic pulsatile turbulence, and inhibits atherosclerosis. Myxedema, congestive heart failure, and sedentary life style reduce cardiac contractility, retard peak end-systolic velocity, decrease diastolic cleansing turbulence, and accelerate atherosclerosis [305,306,422-431].

Like ultrasound, diastolic turbulence inhibits coagulation [432]. Thrombosis is rare in arteries, where turbulence is intense, but thrombophlebitis is common in veins, where turbulence is sluggish [433]. Insoluble fibrin fluctuates in blood in accord with sympathetic nervous system activity, which is increased by allostatic load. Insoluble fibrin entangles red cells and disrupts aggregate patterns, which induces systolic turbulence that increases viscosity, decreases Ejection Fraction, and increases heart rate via the Starling mechanism [161,268,304,392,434]. Insoluble fibrin elevations disrupt red cell aggregates and induce turbulence during systolic acceleration that strains and collapses structurally defective red cells, causing sickle-cell anemia crisis [435-440]. Systolic turbulence also retards peak end-systolic blood velocity, which exaggerates diastolic turbulent lateral forces at the expense of turbulent mixing, elevates blood pressure, increases blood coagulability, and accelerates atherosclerosis [118, 183,185,196,268,385,396,424,432,441-451]. Insoluble fibrin binds red cells into a clot after it reduces turbulent mixing below a threshold [161,432,452].

Blood turbulence normally occurs below the threshold of hearing. Blood pressure cuff inflation constricts arterial diameter, increases flow velocity, and alters the turbulent pulse wave so as to elevate diastolic turbulent frequencies above audible levels at the distal edge of the cuff to produce Korotkoff sounds that are analogous to bruit sounds [453]. The blood pressure cuff measures diastolic turbulent lateral forces in arteries, as opposed to the forward force imparted by cardiac contraction that induces laminar systolic blood flow, so that blood pressure is not directly related to perfusion. Blood pressure is similar among most mammalian species because red cells and body temperature are nearly identical, and cardiac power generation is proportional to body size [394].

Hemodynamic relationships usually appear linear be- cause turbulent variables are maintained within narrow ranges. However, hemodynamic parameters are affected by complex fluctuating exponential interactions of inotropy, chronotropy, temperature, and viscosity that can produce non-linear perturbations. This explains why blood pressure and cardiac output are not linearly related [454,455].

Reptilian red cells enhance systolic turbulence at the expense of cardiac output to prevent atherosclerosis caused by lipoprotein solidification at cool temperatures that exaggerates blood viscosity $[456,457]$. This limits reptile cardiac output and constrains the ability of reptiles to deliver oxygen to peripheral tissues, so that they must rely on anaerobic metabolism to sustain vigorous activity [458]. This explains why reptiles have limited exercise capacity. Reptiles thus thrive in warm environments and their activity is sluggish at low temperatures. Mammals achieve superior exercise tolerance and dominate cold environments by maintaining their body temperature above the level of fat liquefaction, which enables their bi-concave red cells to simultaneously optimize hemodynamic efficiency and atherosclerosis resistance, but this necessitates substantially greater caloric intake $[456,457,459,460]$.

\section{THE TISSUE REPAIR COMPONENT, INFLAMMATION, AND APOPTOSIS}

The tissue repair component continuously maintains and repairs tissues by elevating thrombin levels in injured tissues. It consists of the vascular endothelium, tissue factor hormone, and the enzymatic interaction of Factors VII, VIII, IX, and X. Its activity explains all aspects of the inflammation syndrome, including rubor, calor, dolor, edema, and loss of function.

The selectively permeable vascular endothelium allows the slow, continuous penetration of Factor VII from blood into healthy extravascular tissues, where tissue factor activates it to generate small amounts of thrombin that energize fibroblast mitosis and collagen production to maintain tissues $[83,108,159]$.

Trauma disrupts the fragile vascular endothelium and directly exposes tissue factor to blood enzymes [88, 210, 212]. Factor VII activation by tissue factor initiates the enzymatic interaction and determines its magnitude and location [208,209,212]. Factors IX and X amplify Factor VII thrombin production to moderate levels that energize tissue repair [27,121,215]. Factor VIII then accelerates thrombin production to high levels to generate insoluble fibrin for hemostasis [30,93,94,121,182,410,461]. Pulsatile blood flow thrusts platelets into damaged tissues [462], where thrombin chemotaxis attracts them and insoluble fibrin binds them into a short-lived "white clot" [94]. Thrombin-activated platelets release thromboxane 
that induces local vasoconstriction to temporarily reduce flow and turbulence, which increases coagulability. Rising levels of insoluble fibrin increase local blood viscosity to reduce pulsatile turbulent mixing below a threshold (see "turbulence mechanism" on page 10), whereupon insoluble fibrin binds red cells into a durable, viscoelastic, selectively permeable "red clot" that substitutes for the damaged vascular endothelium by isolating damaged tissues from flowing blood [84,161,169,432, 452]. The enormous molecular size of Factor VIII prevents it from penetrating the clot and interacting with the other enzymes, so that clot formation is self-limiting.

The red clot regulates thrombin in damaged tissues [463,464]. Factors VII, IX, and X penetrate the clot and interact with tissue factor to generate thrombin, which reduces clot permeability and constrains thrombin production [29,126,212,463-465]. Tissue repair then proceeds in predictable stages, energized by optimized thrombin levels [135]. Thrombin elevations in damaged tissues cause cells to release bradykinins, caspases, prostaglandins, chemokines, cytokines, and interleukins. These induce inflammation and enable cell-to-cell communications that coordinate cell repair activities and determine the stages of wound healing [1,466-469]. Inflammation loosens cell connections to facilitate the entry and movement of soluble fibrin and repair cells [47]. Thrombingenerated soluble fibrin moves from blood through inflammatory gaps in the vascular endothelium to enter damaged tissues, where it creates a structural matrix that facilitates repair cell activity [149]. Thrombin elevation in damaged tissues attracts fibroblasts, myoblasts, osteocytes, and immune cells via chemotaxis, and these cells move through inflamed tissues into damaged tissues, where they proliferate and produce collagen, muscle, bone, and immune activity to fill empty spaces, replace damaged tissues, inhibit infection, and remove debris and foreign substances [108,109,159]. Thrombin-energized angiogenesis perfuses proliferating repair tissues. Thrombin-energized increases in cell metabolism cause temperature elevation in healing tissues. [133] As the repair process nears completion, proliferation and spreading of the vascular endothelium restores the normal barrier between blood enzymes and tissue factor in extravascular tissues, which reduces thrombin generation to maintenance levels. This undermines clot integrity and repair cell viability, so that the clot disintegrates, apoptosis facilitates wound closure by actomyosin, and structural integrity is restored [34,38,470,471].

The tissue repair component automatically forms abscesses, furuncles, and fistulas. Fibroblasts produce collagen to form barriers that isolate bacteria and foreign materials, and inflammation weakens surrounding tissues to create passages that expel them from the body. Trauma, burns, toxic chemicals, sepsis, and radiation disrupt the vascular endothelium, activate the tissue repair component, and release inflammatory substances that sensitize nociceptors and activate the capillary gate component. The delay between tissue damage and nociceptor sensitization explains the delayed onset of pain caused by radiation [213].

\section{ANESTHESIA, ANALGESIA, ALLOSTASIS, AND THE THREE PATHWAYS OF SRM ACTIVATION}

Three independent pathways activate the SRM and focus its powerful effects: the spinal pathway, the cognitive pathway, and the tissue pathway. Individual stressors and combinations of stressors activate these synergistic pathways in various magnitudes, locations, intervals, and combinations, so that the manifestations of SRM activity appear chaotic and confusing. Analgesia inhibits the spinal pathway, and anesthesia inhibits the cognitive pathway. There are no clinically available means to inhibit the tissue pathway.

\section{THE SPINAL PATHWAY}

The spinal pathway consists of peripheral nociceptors in the skin and internal organs that detect noxious stimuli and activate the SNS via peripheral nerves and spinal cord internuncial pathways. Nociceptors detect vibration, temperature, inflammation and tissue disruption, but are insensitive to radiation, sepsis, and many toxic chemicals [472]. Spinal pathway activity is called nociception. Descending cortical pathways inhibit nociception, so that their absence exaggerates nociception [473]. Analgesic agents inhibit nociception by disrupting spinal pathway activity. Cyclo-oxygenase (COX) inhibitors prevent inflammation that activates nociceptors. Opioids inhibit spinal cord nociception pathways. Lidocaine, marcaine, and other local analgesics block the function of peripheral nerves, spinal cord pathways, and autonomic nerve endings that conduct nociception signals. The following examples illustrate spinal pathway function:

1) Spinal Pathway nociception resists anesthesia in safe and practical doses [153,474-479]. This explains the release of stress hormones (VWF, cortisol, epinephrine, glucagon, etc.) during surgery despite dangerously deep levels of anesthesia. It also explains spinal cord "windup" syndrome that causes problematic muscle tension and unexpected muscular movements during surgery despite deep levels of anesthesia.

2) Spinal cord damage at or above the level of $T 5$ causes autonomic dysreflexia. The cognitive pathway no longer responds to nociception, so that pain is eliminated, but spinal pathway nociception, freed from descending cortical inhibition, causes harmful SNS hyperactivity that is little affected by anesthesia $[473,480]$. 
3) Cortical inhibition remains intact in spinal cord damage below the level of T5, and it inhibits spinal cord nociception pathways and synergizes the effects of general anesthetic agents in a manner analogous to analgesia [481-483].

4) Analgesia prevents both nociception and pain and thereby reduces surgical morbidity and mortality more effectively than anesthesia, which prevents only pain, fear, and apprehension (see Cognitive Pathway below) [153,479,481,484-504].

5) Pediatric anesthetic methods such as the once popular "Liverpool technique" that rely on inhalation agent supplemented by muscle relaxants do not adequately control stress. Fetuses and newborn babies cannot understand language and perceive danger, but their nociception pathways are fully functional so that they require analgesia as well as anesthesia for surgical safety [234,505510].

6) I hypothesize that cortical damage sometimes impairs descending inhibition of spinal cord activity, so that spinal cord nociception pathway activity is exaggerated in the manner of autonomic dysreflexia (see \#2 above). I further hypothesize that general anesthesia without supplemental analgesia exaggerates nociception by inhibiting cortical activity that is essential for descending pathway inhibition.

7) Nociceptors are not directly sensitive to radiation and some toxic chemicals, but they are indirectly and belatedly activated by inflammation that is induced by these forms of stress. For example, sunburn is initially painless, but becomes painful the day after sun exposure due to the inflammatory effects of radiation damage.

\section{THE COGNITIVE PATHWAY}

The cognitive pathway consists of conscious awareness generated by corticofugal mechanisms that assesses environmental hazards via sensory input including sight, smell, sound, vibration, and nociception. It activates the SNS and the HPA axis via hypothalamic pathways that are independent of the spinal pathway [191,250,511-514]. The cognitive pathway also inhibits spinal pathway nociception via descending pathways from the brain to the spinal cord [473]. Conscious awareness interprets nociception as pain $[515,516]$. Inhalation anesthetics are hypnotic agents that obtund consciousness. Even moderate inhibition of conscious awareness by hypnotic agents can eliminate pain, but hypnotic agents have little effect on nociception. The benefits of hypnotic inhalation anesthetic agents such as ether, halothane, chloroform, Ethrane, Isoforane, Desflurane and Sevoflurane are equivalent to those of intravenous hypnotic agents such as benzodiazepines, barbiturates, Propofol, ketamine, Etomidate, Althesin, Viadril, and alcohol.
Emotional mechanisms modulate cognitive pathway activity. This explains allostasis, which is the subconscious alteration of behavior and physiology in accord with prior experience. Hyperthymestic Syndrome demonstrates that the brain automatically records permanent audiovisual memories of all waking moments throughout life, and that these normally suppressed memories activate emotions and SNS activity [517,518]. Sleep halts the recording process while the emotional mechanism engages in the process of dreaming, wherein it automatically compares and contrasts previously stored memories to identify threatening circumstances [266,511,512,519]. This enables the pre-emptive perception of danger, whereupon emotional mechanisms automatically generate anxiety, rage, fear and apprehension, and activate the SNS and the HPA axis to facilitate "fight or flight" [520, 521]. This activates capillary hemostasis, and, increases blood viscosity [522], which limits blood loss in the event of subsequent injury. It also concentrates blood flow in critical organs such as heart, lung, and brain, whose tissues resist capillary hemostasis. The HPA axis simultaneously releases epinephrine, glucagon, cortisol, and other stress hormones. These combined effects explain the tachycardia, hypertension, and hyperglycemia, other reactions associated with acute and chronic allostasis, and how these reactions are progressively altered by accumulating memories and their ongoing manipulation by emotional mechanisms [523].

The emotional mechanism plays an important survival role in animals, which often face life or death confrontations and lack the reasoning ability of humans. Idiopathic Insomnia demonstrates that sleep and dreaming are not essential in humans [230,522,524-526]. However, occult allostasis explains neurosis in humans. It also explains how emotions alter the perception of pain and danger, which suggests new treatments for chronic pain and neurosis [527].

The following examples illustrate cognitive pathway activity:

1) The cognitive pathway activates the SNS despite the absence of nociception. One may not sense the pain of a dentist's drill, but one can still perceive vibration, pressure, the noise of the drill, and the comments of the dentist and his staff. One anticipates pain and danger consciously, even if none is present, and this activates the SNS [230,524-526,528-531].

2) The cognitive pathway resists analgesia in clinically practical doses, because sight, smell, vibration, and sound perception remain intact. Spinal and epidural analgesia, analgesic block techniques, and high-dose opioid analgesia for cardiac surgery often require supplementation with hypnotic agents to prevent sharp increases in blood pressure, pulse rate and muscle activity caused by frightening sounds and sensations, even though nociception 
and pain are absent [153,474-478,532,533].

3) Anesthesia increases surgical safety by abolishing consciousness, fear, apprehension, and pain, but it cannot prevent harmful spinal pathway nociception in clinically practical doses [250,266,522,528,534-542].

4) Acute allostatic load, such as occurs in uninjured earthquake victims, activates the cognitive pathway and causes acute and residual elevations of VWF, Factor VIII activity, blood viscosity, blood coagulability, myocardial infarction, stroke, heart rate and blood pressure in accord with the severity of fear. This explains how people are sometimes frightened to death [441].

5) Chronic emotional allostatic load, such as job difficulties, elevates VWF and Factor VIII activity, accelerates atherosclerosis, and shortens life span [191,230,514, 520,529-531,543,544].

6) Moderate alcohol consumption inhibits consciousness and mitigates emotional distress, which reduces SNS activity, thus explaining its ability to prevent heart disease and enhance longevity [532,545,546].

7) Analgesia prevents infarction during anesthetic emergence, when the sudden restoration of cognitive pathway function and the ability to perceive pain and danger synergizes with spinal pathway nociception to harmfully exaggerate capillary gate component activity [210].

\section{THE TISSUE PATHWAY}

The tissue pathway consists of the vascular endothelium, tissue factor, and Factor VII. The vascular endothelium manufactures tissue factor, excretes it into extravascular tissues, and insulates it from flowing blood. Tissue damage disrupts the vascular endothelium and exposes tissue factor to Factor VII in flowing blood, which activates Factor VII and initiates tissue repair. The tissue pathway activates the tissue repair component in accord with the magnitude and location of injurious forces that disrupt the vascular endothelium, expose tissue factor to Factor VII in blood, and release tissue factor into blood circulation with systemic consequences.

Brain, lung, nerves, autonomic ganglia, cervix, blood vessel adventitia, epithelium, mucosa, glomeruli, and placenta are rich in tissue factor [139,144,210,213,301, 547,548]. This explains why these tissues are "targets" for positive feedback in stress-related conditions. For example, severe brain and burn injuries release tissue factor into systemic circulation and exaggerate morbidity and mortality. Lung tissue reacts violently to microbes, antigens, and chemicals, causing lethal overproduction of soluble fibrin that floods alveolar spaces and airway passages and disrupts gas exchange in asthma, pneumonia, influenza, and poison gas exposure. Brain, lung, kidney, nerves, skin, cervix, and peri-arterial tissues are more likely to develop malignancies or be the site of metastasis than other tissues. Placenta, brain, kidney and lung function are primary targets in eclampsia. Adult Respiratory Distress Syndrome (ARDS) is usually the first manifestation of Multi-Organ Failure Syndrome (MOFS) that primarily affects lung, brain, and kidney.

The following examples illustrate tissue pathway activity:

1) Pneumonia and influenza insensibly disrupt the vascular endothelium in lung tissues that are rich in tissue factor, causing profuse soluble fibrin exudates that flood alveolar spaces, disrupt gas exchange, and promote collagen generation (fibrosis) [146,147,549].

2) Inhaled antigens imperceptibly deposit on airway passages and induce soluble fibrin generation on their inner walls. This has minor effect during inhalation, when airway diameters are increased, but inhibits airflow during exhalation, when airway diameters are reduced, causing asthma [47,141,149,213,281,550,551].

3) Bacterial products that enter the bloodstream cause sepsis by insensibly increasing the permeability of the vascular endothelium and releasing tissue factor into the blood, causing positive feedback that exaggerates thrombin and soluble fibrin generation. Thrombin energizes inflammatory changes that enable soluble fibrin to enter extravascular tissues, causing tissue edema and organ dysfunction [140,552].

4) Brain and burn injuries release large amounts of tissue factor into blood circulation, causing abnormal systemic Factor VII activation that overwhelms inhibitory mechanisms and induces SRM hyperactivity and positive feedback that exaggerates morbidity and mortality [213].

5) Radiation does not directly activate peripheral nociceptors, but it damages the vascular endothelium, causing thrombin generation and positive feedback that energizes the release of inflammatory substances that activate nociceptors, causing belated pain. For example, skin damage due to sun exposure is initially painless and invisible, but the gradual onset of inflammatory effects caused by radiation damage produces a delayed painful reaction.

6) Site-inactivated tissue factor neutralizes the tissue pathway and inhibits the effects of sepsis [553-555].

7) Amniotic fluid is rich in tissue factor. Amniotic fluid embolus suddenly introduces large amounts of tissue factor into circulation, which activates Factor VII and induces capillary gate component hyperactivity that triggers spontaneous systemic coagulation activity that depletes coagulation precursors such as fibrinogen and fibronectin, causing defective coagulation activity known as Disseminated Intravascular Coagulation (DIC) (see below) [184].

\section{POSITIVE AND NEGATIVE FEEDBACK}

The tissue repair pathway activates the tissue repair 
component in accord with the magnitude and location of injurious forces that affect the vascular endothelium. For example, invasive surgery releases greater amounts of tissue factor into circulation than minor surgery, thereby exaggerating morbidity and mortality [454]. The semiindependent and synergistic spinal and cognitive pathways both activate the capillary gate component, in accord with combinations of sight, sound, smell, vibration, and nociception. Combinations of anesthesia and analgesia synergistically inhibit sympathetic nervous system activity and control capillary gate component activity.

The tissue repair component activates Factor VII, amplifies thrombin production, and generates soluble fibrin $[177,368]$. The capillary gate component activates Factor VIII, accelerates thrombin production, and generates insoluble fibrin [82,140,141,556-558]. The activity of each component exaggerates that of the other in a "chaotic" manner [454], because both share the enzymatic interacttion of Factors VII, VIII, IX and X [297]. The simultaneous, synergistic activation of both components induces "positive feedback" so that peak SRM activity occurs several hours after injury [129]. The constantly fluctuating activities of the three synergistic pathways enable the SRM to focus its powerful effects and generate an infinite variety of manifestations [281,284,502-504,536,559563].

As stressors subside, “negative feedback" restores homeostasis via clot formation and tissue repair that progressively reduces thrombin production to maintenance levels. Likewise, parasympathetic activity, Stoichiometric ATIII, TFPI, TPA and protein C mobilization [141, 148,281,564-566] restores homeostasis by inhibiting Factor VII and Factor VIII activity and accelerating the spontaneous disintegration of insoluble fibrin [116,141, 281,519,550,567-572]. However, prolonged Factor VIII half-life and spinal cord "wind up" can cause residual capillary gate component hyperactivity to linger long after stressors subside [139,144,148,157,210,573-575].

\section{THE INFLAMMATION SYNDROME AND THE SRM}

SRM activity explains the nature of disease, disease symptoms, and the relationships of physiology, pathology and stress[4]. Radiation, surgery, trauma, chemicals, sepsis, obesity, allergic reactions, myopathy, peritonitis, atherosclerosis, rheumatoid diseases, diabetes, exercise, malignancy, and other forms of stress cause systemic SRM positive feedback and hyperactivity that elevates thrombin generation and produces local or systemic inflammatory changes that can be either visible or occult.

Inflammation is a medical syndrome that is classically described as a combination of dolor (pain), rubor (redness), calor (heat), tumor (edema), and Functio laesa (loss of function). The simultaneous appearance and resolution of these seemingly unrelated visible symptoms remains unexplained. SRM activity explains all aspects of inflammation. It is most easily understood in terms of tissue repair. Coagulation is the first event in tissue repair. It stems blood loss and then governs thrombin generation in damaged tissues. Thrombin energizes the cellular release of chemokines, cytokines, prostaglandins, and bradykinins. These increase capillary perfusion, which causes redness (rubor); sensitize nociceptors, which causes pain (dolor); loosen cell connections, which enables chemotaxis; and enable cell-to-cell communications that govern the orderly sequence of cell activities during the repair process. Thrombin converts fibrinogen to soluble fibrin, which escapes from blood through inflammatory gaps in the vascular endothelium and diffuses into inflamed and damaged tissues. This causes tissue swelling and edema (tumor). Repair cells multiply and differentiate to increase immune activity and generate granulation tissue that fills wound cavities and replaces damaged tissues. This intense metabolic activity generates heat and elevates tissue temperature (calor). Pain and swelling immobilizes inflamed joints and tissues, causing loss of function (Functio laesa). The integrity of the vascular endothelium is restored as tissue repair nears completion, and this causes thrombin generation and inflammation to subside to maintenance levels. Thrombin starvation then undermines clot integrity, shrinks granulation tissues and draws wound edges together via apoptosis, and resolves the tissue repair process.

\section{INFLAMMATION AND ATHEROSCLEROSIS}

The SRM explains why inflammation is involved in atheroma formation. Atherosclerosis is a complex phenomenon that is explained by a combination of inadequate blood turbulence that causes particulate deposits to accumulate on the inner surfaces of arteries, and SRM activity that generates inflammation and plaque formation in response to these deposits.

Inadequate blood turbulence explains why atherosclerosis begins on the greater curvatures of arteries, where shear stress and systolic velocity decline and diastolic turbulence decreases exponentially [405-407,417-421]. High flow rates are necessary to generate turbulence that prevents sludge deposits in oil pipelines [404]. Similarly, pulsatile arterial flow operates at the threshold of peak diastolic turbulence to prevent particulate deposits on the inner walls of arteries that are the initial cause of atheroma formation. The vascular endothelium adjusts arterial diameter via neuromuscular control to optimize turbulent cleansing [236,405-407].

Arterial deposits activate the tissue repair component 
[415]. Tissue repair component activity then causes thrombus formation, inflammation, tissue factor accumulation, fibrosis, and cholesterol trapping that produces atherosclerotic plaque [196,221,222,327,408-416].

Diastolic turbulence increases exponentially with endsystolic velocity. Exercise increases cardiac contractility, elevates peak end-systolic velocity, exaggerates diastolic pulsatile turbulence, and inhibits atherosclerosis. Myxedema, congestive heart failure, and sedentary life style reduce cardiac contractility, retard peak end-systolic velocity, decrease diastolic cleansing turbulence, and accelerate atherosclerosis [305,306,422-431]. The natural decline in cardiac index with advancing age accelerates atherosclerosis and explains its prevalence in old age.

Shear stress and viscosity both affect turbulence, but viscosity has no effect on shear stress and vice-versa. This explains why shear stress cannot explain atherosclerosis resistance in Down's Syndrome [576,577], hemophilia, von Willebrand coagulopathy [578], and patients treated with anticoagulants.

\section{INFLAMMATION, APOPTOSIS, AND MALIGNANCY}

The SRM provides a cohesive explanation of inflammation, apoptosis, and malignancy. The simplest explanation of apoptosis is thrombin starvation of repair cells. This normally occurs during tissue repair resolution. The SRM continuously governs thrombin levels in all tissues to energize, and thereby regulate, tissue repair. SRM hyperactivity generates thrombin elevations that induce repair cell hyperactivity that causes inflammation, which loosens cell connections to enable cellular repair activeties. As tissue repair nears conclusion, declining SRM activity restores thrombin to maintenance levels, which causes thrombin-dependent repair cells to undergo apoptosis. This shrinks granulation tissues in wound cavities and enables wound closure.

Cellular thrombin receptor configurations become altered during both embryological development and tissue repair, and exaggerated repair cell mitosis and metabolism during normal tissue repair causes abnormal chromosome morphology, so that the microscopic appearance of normal repair cell hyperactivity cannot be distinguished from malignancy [204,579-592]. Malignancy is an abnormal manifestation of tissue repair activity that occurs when prolonged and exaggerated positive feedback causes SRM repair hyperactivity to become selfsustaining [204,210,593]. Malignant cells invade normal tissues, release tissue factor, activate nervous sensors, and cause a "vicious cycle" of positive feedback that sustains abnormal thrombin elevations that inhibit the apoptosis and resolution that normally occurs at the conclusion of the tissue repair process [29,82,216,217,594597]. For example, uncontrolled osteomyelitis sometimes evolves into osteosarcoma. Malignancy induces systemic SRM hyperactivity that causes systemic inflammatory effects and increases blood viscosity and coagulability. This increases the risk of infarction and metastasis. Brain, nerve, retina, ovary, placenta, lung, artery, and cervix tissues are rich in tissue factor and therefore especially vulnerable to both primary malignancy and metastasis [210,552,556,557,598-600]. SRM activity thus explains the close association of malignancy with chronic disease, environmental stress, inflammation, elevated Factor VII and Factor VIII activity, increased blood viscosity and coagulability, accelerated atherosclerosis, and seemingly unrelated forms of malignancy [556-558,566,601-605].

The SRM indicates an effective strategy for cancer prevention and treatment. Combinations of analgesia that inhibits the spinal pathway, anesthesia that inhibits the cognitive pathway, and treatments that inhibit the tissue pathway can mitigate positive feedback reduce the risk of malignancy, and induce apoptosis to cure malignancy [505-507,606,607].

The currently prevailing belief that defective DNA causes cancer is unfounded, and treatments based on this concept are notoriously ineffective. "The Secret History of the War on Cancer” by Devra Davis explains how current cancer beliefs and treatments became entrenched [592]. Drs. Goodman and Gilman of pharmacology textbook fame demonstrated that toxic war gases reduce white blood cell counts in leukemia, which they assumed was beneficial. Then they tested their toxic treatment on a mouse with a solid tumor, whereupon the tumor shrank dramatically. Though subsequent experiments produced unimpressive results, they assumed that they had discovered an effective cancer treatment strategy. Soon thereafter, the discovery of DNA provided the seemingly reasonable rationale that DNA damage causes cancer, which implies that killing cancer cells cures cancer. Thus chemotherapy seeks to induce apoptosis (programmed cell death) in malignant cells [608], while surgery and radiation therapy seek to extirpate and destroy them. Unfortunately, these conventional cancer treatments are harmful and unreliable. Surgery, radiation, and toxic chemicals all increase SRM activity, which explains why conventional treatments are accompanied by increased risk of cancer and cardiovascular disease [552,556,557,598$600]$. They are plagued by toxic side effects and physical disfiguration, bedeviled by the subsequent appearance of other, seemingly unrelated, forms of cancer, and they increase morbidity and mortality from atherosclerosis, infarction, and pulmonary embolus [582]. They sometimes succeed, but only because hyperactive repair cells are more vulnerable to radiation and toxic chemicals than quiescent cells, and spontaneous apoptosis sometimes occurs despite the treatments. Conventional cancer treatments are comparable to fighting fire with oil. This can 
succeed, but only if enough oil is poured fast enough to smother the fire. Otherwise, the oil may accelerate the fire, and residual oil increases the risk of subsequent fires.

\section{INFLAMMATION AND SURGICAL STRESS}

Surgery simultaneously activates all three SRM pathways, causing positive feedback in accord with the duration and degree of sympathetic nervous system activation and tissue factor released into systemic circulation by surgical tissue disruption [505-507,606,607]. This manifests as symptoms distant from the location and time of surgery that are known as the surgical stress syndrome $[238,239,328,474,475,482,487,505,506,510,532,533,546$, 561,609-628]. Analgesia controls nociception, and prevents SNS activation via spinal cord pathways. Anesthesia controls conscious awareness, and prevents SNS activation via hypothalamic pathways that are independent of spinal cord nociception pathways. Either anesthesia or analgesia can independently reduce positive feedback and surgical stress to the point that most patients survive surgery [13,132], but outcome is further enhanced if synergistic combinations of anesthesia and analgesia are maintained continuously throughout surgery [233,238, $243,328,465,533,610,621,629-648]$. Such combinations beneficially prevent thrombin acceleration, inhibit thrombin-induced immune activity and inflammatory effects [601], and reduce blood viscosity and coagulability. This improves tissue perfusion and oxygenation, protects organ function, maintains cardiac output, reduces blood pressure, increases ejection fraction, slows heart rate via the Starling Mechanism, and reduces the risk of malignnancy and heart disease in the distant aftermath of surgery $[201,210,213,479,508,551,649]$. Theoretically, the additional neutralization of tissue factor released into blood during surgery should abolish the surgical stress syndrome.

\section{INFLAMMATION AND SEPSIS}

The thrombin-energized complement cascade attacks bacteria that enter the bloodstream [19]. Bacterial products cause inflammatory gaps to form in the vascular endothelium that allow soluble fibrin to diffuse from the bloodstream into extravascular tissues and organs, which causes tissue edema and disrupts organ function [47,141, $144,218,281,550,551]$. Gaps in the vascular endothelium also allow tissue factor to escape into flowing blood, which activates Factor VII, which then interacts with Factors VIII, IX, and X to generate insoluble fibrin, increase blood viscosity and coagulability, and induce positive feedback in the SRM [213,281]. SRM hyperactivity thus explains the devastating inflammatory effects of sepsis.

\section{SYSTEMIC INFLAMMATORY SYNDROMES}

Eclampsia, amniotic fluid embolism, Disseminated Intravascular Coagulation (DIC), Multi-Organ Failure Syndrome (MOFS), and Adult Respiratory Distress Syndrome (ARDS) are all closely related. Combinations of stressful forces and stressful stimuli cause these pathologies by inducing severe systemic SRM hyperactivity and positive feedback, causing systemic inflammatory effects that disrupt organ function $[139,144,148,157,210,573-$ 575].

MSOF commonly occurs after severe trauma, which causes nociception, pain, and fear and releases tissue factor into blood circulation. Trauma is often complicated by sepsis, cold, and other stresses that exaggerate the risk and severity of SRM hyperactivity $[145,155,156$, $175,307,650-660]$. ARDS is typically the first manifestation of MSOF, because lung tissue possesses more tissue factor than other organs and is therefore affected sooner [661]. Inflammatory effects in the lung cause excessive soluble fibrin production that interferes with gas exchange. Pulmonary exudates in ARDS are similar to those in pneumonia and influenza, except that bacterial and viral invasion of the lung triggers SRM hyperactivity via direct lung tissue effects [4].

\section{ECLAMPSIA AND AMNIOTIC FLUID EMBOLUS}

Eclampsia is analogous to MSOF, except that it occurs in pregnant women. Pregnancy is a stressful condition characterized by SRM hyperactivity that elevates blood levels of Factor VIII, generates insoluble fibrin, and increases blood viscosity and coagulability [156,175,194, $657,658,662,663]$. This is partially offset by Hemodilution anemia during pregnancy that increases blood turbulence and inhibits atherosclerosis [7,8]. Additional stress due to diabetes, obesity, and sepsis (commonly caused by occult urinary tract infections during pregnancy) exaggerates SRM hyperactivity and increases the risk and severity of eclampsia [51,81,112,113,133,138,200, 285,552-555,587,596,664-673]. The tranquilizing effects of smoking mitigate the severity of eclampsia $[21,81,130$, 673,674].

Eclampsia increases the risk of DIC, especially in the presence of amniotic fluid embolus. The developing fetus sheds tissue factor into amniotic fluid throughout pregnancy, so that amniotic fluid contains increasing concentrations of tissue factor as the pregnancy progresses. If amniotic fluid enters systemic circulation, it drastically increases Factor VII activity [193,200,554,555]. Factor VII then interacts with Factors VIII, IX, and X, which cause blood viscosity and coagulability to suddenly rise 
above a critical threshold where spontaneous systemic coagulation (DIC) begins [675-679].

\section{DISSEMINATED INTRAVASCULAR COAGULATION (DIC)}

The conversion of fibrinogen to soluble and insoluble fibrin is a complex process that involves several enzymes and precursors. Disseminated Intravascular Coagulation (DIC) illustrates how this process can go awry in several ways. DIC is usually caused by the abnormal entry of tissue factor into systemic blood circulation due to surgery, trauma, sepsis, and amniotic fluid embolus. This activates Factor VII, overwhelms inhibitory mechanisms (Protein C, TFPI, and ATIII), and initiates excessive intravascular generation of thrombin, soluble fibrin, and insoluble fibrin. The risk and severity of DIC is exaggerated by sensory stresses that activate Factor VIII. Insoluble fibrin exaggerates blood viscosity, which reduces blood turbulence below a threshold, whereupon spontaneous systemic coagulation suddenly begins $[193,552$, $680,681]$. This rapidly consumes and depletes coagulation enzymes and precursors and distorts the coagulation process. Thrombin converts fibrinogen to soluble fibrin, which depletes fibrinogen [194,682]. Exaggerated Factor VIII activity converts Factor X to Factor XIII to convert soluble fibrin to insoluble fibrin, but this depletes Factor VIII and Factor X [163,172,188,194]. Factor XIII installs "cross-links" of fibronectin and plasminogen to soluble fibrin to generate insoluble fibrin, and this consumes both Factor XIII and fibronectin [680,681]. Shortages of Factor XIII and fibronectin cause soluble fibrin to accumulate to excessive blood levels [169]. Fibronectin exhaustion also causes Factor XIII to produce defective forms of insoluble fibrin with inadequate fibronectin "cross-links" [160]. These imbalances cause soluble fibrin to form abnormal attachments to the pathological clots to produce "microthrombi". Soluble fibrin also deposits on arterial walls $[197,198,683]$. The abnormal coagulation activity reduces circulating red cell mass, which exaggerates blood turbulence and further inhibits effective coagulation. These abnormalities and imbalances cause the generalized failure of hemostasis that characterizes DIC [401,460,684].

DIC often occurs in patients who undergo extensive surgical intervention in the immediate aftermath of major trauma and massive blood loss $[11,200,568]$. Trauma and surgery both release tissue factor into systemic circulation and increase Factor VII activity, causing SRM hyperactivity and positive feedback $[116,184,194,286,460$, 542,660,684-686]. In addition, trauma patients are typically subjected to starvation, sepsis, hypothermia, fear, pain, hypoxia, and iatrogenic hyperoxia, and these additional forms of stress exaggerate positive feedback and SRM hyperactivity.
Misguided treatments can confuse and aggravate DIC. Crystalloids, colloids, and starch solutions briefly dilute coagulation precursors and enzymes, alter blood turbulence, and exaggerate blood pressure, which conveys the misleading impression that they improve cardiac output $[384,687,688]$. DIC removes red cells from circulation, causing anemia that exaggerates blood turbulence and inhibits coagulation [457]. Blood transfusion corrects the anemia, reduces blood turbulence, and restores blood coagulability, but excessive transfusion with washed, packed red cells can reduce blood turbulence below a critical threshold and aggravate the problem. Reduction of body temperature even slightly below normal mammalian body temperatures causes lipoprotein solidification, which harmfully increases blood viscosity [660]. Cold stress activates the SRM and increases blood levels of insoluble fibrin, which also increases blood viscosity [401]. Severe hypothermia impairs SRM enzymes, and inhibits hemostasis [459]. Metabolic acidosis and hypothermia synergistically impair hemostasis [657].

\section{EMBRYOLOGY, APOPTOSIS, AND THE SRM}

As expected by the previous generation of stress theorists and researchers, the SRM explains the mysteries of embryological development. Cell proliferation and differentiation occurs faster during embryological development than at any other time of life. Symmetrical and asymmetrical structural development occurs in three dimensions. Ancient structures and organ systems such as the notochord and primitive renal systems appear and then or coalesce via apoptosis. The DNA mechanism by itself cannot explain these phenomena, because it does not explain how genetic information controls cell proliferation, cell maintenance, cell differentiation, and apoptosis.

Most presently available DNA information derives from prokaryotes, because these are easy to study. Prokaryotic (bacterial) cells employ their outer membrane for respiration, which limits them to single-cell existence, small size, and a few shapes that optimize surface area. They have simple internal structures and only one type of DNA that floats freely in the cytoplasm and transmits its genetic information via a straightforward mechanism that employs RNA templates to generate proteins. Unfortunately, the eukaryotic cells in complex animal are considerably more complex than prokaryotic cells, so that prokaryote information is often irrelevant to animal biology. Eukaryotic cells are believed to have originated when a "parent" cell somehow engulfed other types of previously free-living single-cell organisms (mitochondria, Golgi apparatus, endoplasmic reticulum, etc.) that subsequently became symbiotic organelles. The DNA of the "parent" cell exists in the form of chromosomes that are enclosed within a nuclear membrane that isolates 
them from the cytoplasm. The engulfed organisms persist in the form of cytoplasmic "organelles" including mitochondria, endoplasmic reticulum, Golgi apparatus, and vacuoles. These possess DNA that replicates and functions independent of chromosome DNA in the nucleus. Eukaryotic cells utilize the mitochondria for aerobic respiration, which enables them to become much larger than prokaryotes, assume diverse shapes, engage in locomotion, and build multicellular life forms [689].

Unlike the DNA of prokaryotes, the nuclear DNA of eukaryotic cells transmits its genetic information via mechanisms that are not yet understood. Eukaryotic nuclear DNA consists of short protein-encoding segments that are interspersed with large sections of "junk" DNA that remains inert in the mature individual. "Junk" DNA was originally assumed to lack function, but recent research reveals that it consists at least in part of "introns" that control embryological development. However, introns do not produce proteins in the manner of DNA in prokaryotic cells. Modern researchers therefore suspect that introns control embryological development via a cytoplasmic mechanism that is different from prokaryote DNA mechanisms [31,690-692].

The previous generation of researchers expected that Selye's mechanism would function as a "companion mechanism" that works closely with DNA to convert genetic information into embryological structures. They postulated that DNA becomes quiescent once embryological development is complete, while the "companion", mechanism remains active throughout life to maintain and repair mature structures.

Both viewpoints may be correct. Thrombin receptors are present on the outer surface of all animal cells thus far tested, and they determine how cells respond to thrombin elevations. Mature animal cells have stable thrombin receptor configurations that characterize cell types, but cells alter these configurations during tissue repair and malignancy, and they can presumably alter them during embryological development as well $[25,81$, 693]. Animal cells also possess precise timing mechanisms that are critical to embryological development [694]. The simplest explanation is that introns control embryological cell proliferation, differentiation, and apoptosis by releasing tissue factor and altering thrombin receptor configurations in specific locations at precise time intervals. Thrombin receptor configurations control cell function, and tissue factor activates the SRM to generate thrombin that energizes cell activity. Such a mechanism would explain how introns govern embryological development in three dimensions. For example, it would explain how both right and left thumb development proceeds simultaneously, even though there is no direct communication between the two sets of tissues. This mechanism would explain how embryological cell differentiation and proliferation occurs faster during embryological development than at any other time of life, why introns do not generate proteins, and why defects in Factors VII, $\mathrm{X}$ and tissue factor disrupt embryological development, while defects in Factors VIII, IX, and XIII do not.

\section{CONCLUSIONS}

There is growing frustration with the lack of theoretical progress in biological and medical science [695,696]. The DNA paradigm has dominated research since stress theory was abandoned. DNA has revolutionized genetics and criminal justice, but it has failed to explain either embryological development or adult biology. The Genome Project illustrates this failure. It cost billions of dollars and it promised to revolutionize medicine, but it failed to produce a single treatment [695]. Scientific history suggests that the DNA paradigm must soon be replaced or reinvigorated by a new paradigm that will re-inspire scientific research [697].

Meanwhile, Selye's theory has never been refuted, and its virility remains undiminished. The SRM corroborates stress theory, complements and extends DNA theory, and exceeds the previous predictions of stress researchers. Inflammation and apoptosis illustrate the power of stress theory. Apoptosis explains key aspects of tissue repair, embryology, and malignancy. Inflammation appears in diverse circumstances and causes disparate symptoms (pain, swelling, heat, redness, and loss of function) that can now be understood as manifestations of SRM hyperactivity. Inflammation plays an essential role in tissue repair, but it can be harmful or even lethal when excessive, so that control of SRM hyperactivity confers improved outcome.

The SRM explains far more than inflammation and apoptosis. It provides fresh insights to embryology, evolution, taxonomy, anatomy, behavior, intelligence, pharmacology, physiology, pathology, stress, and their relationships. It enables Selye's Universal Theory of Medicine, which promises to elevate medicine from an art based on experiment to a science founded on theory. Stress theory is thus poised to complement and rejuvenate the DNA paradigm, and inspire productive research and pharmaceutical development. It portends a new era of health, longevity, productivity, and freedom from the eternal scourge of disease.

\section{REFERENCES}

[1] Chanson, M., Derouette, J.P., Roth, I., Foglia, B., Scerri, I., Dudez, T. and Kwak, B.R. (2005) Gap junctional communication in tissue inflammation and repair. Biochimica et Biophysica Acta, 1711, 197-207.

[2] Yehuda, R.M.B. (2005) Behavioral stress response: Pro- 
tective and damaging effects. Annals ed., New York Academy of Science, 331.

[3] Fink, S., (2005) Beyond bad: New ways of considering the stress response. New York Academy of Sciences Magazine, 205, 2.

[4] Coleman, L.S. (2010) A stress repair mechanism that maintains vertebrate structure during stress. Cardiovascular \& Heamatolological Disorders-Drug Targets, 10, 111-137.

[5] Petrovitch, C.T. (2003) An approach to the patient who may have a bleeding disorder. American Society of Anesthesiologists Annual Meeting, San Francisco, 11-15 October 2003, 186.

[6] Coleman, L.S. (2005) Insoluble fibrin may reduce turbulence and bind blood components into clots. Medical Hypotheses, 65, 820-821. doi:10.1016/j.mehy.2005.05.002

[7] Coleman, L.S. (2005) An improved explanation of atherosclerosis. PLoS Medicine, 2, e98.

[8] Coleman, L.S. (2006) Atherosclerosis may be caused by inadequate levels of turbulence and mixing. World Journal of Surgery, 30, 638-639.

doi:10.1007/s00268-005-0375-4

[9] Coleman, L.S. (2005) A capillary hemostasis mechanism regulated by sympathetic tone and activity via factor VIII or von Willebrand's factor may function as a "capillary gate” and may explain angiodysplasia, angioneurotic edema, and variations in systemic vascular resistance. Medical Hypotheses, 66, 773-775.

[10] Coleman, L.S. (2006) To the editor: Is von willebrand factor a hormone that regulates a coagulation mechanism? World Journal of Surgery, 30, 479-481.

[11] Coleman, L.S. (2007) A hypothesis: Factor VII governs clot formation, tissue repair and apoptosis. Medical $\mathrm{Hy}$ potheses, 69, 903-907. doi:10.1016/j.mehy.2007.01.063

[12] Coleman, L.S. (2006) A testable hypothesis that may explain the morbidity and mortality caused by surgical stress. Anesthesia \& Analgesia, 103, 1589-1590. doi:10.1213/01.ane.0000246448.53174.c5

[13] Coleman, L.S. (2012) 30 Years lost in anesthesia theory. Cardiovascular \& Hematological Agents in Medicinal Chemistry, 10, 31-49.

[14] Kerr, J.F., Wyllie, A.H. and Currie, A.R. (1972) Apoptosis: A basic biological phenomenon with wide-ranging implications in tissue kinetics. British Journal of Cancer, 26, 239-257. doi:10.1038/bjc.1972.33

[15] Itakura, T., Yamamoto, K., Tohyama, M. and Shimizu, N. (1977) Central dual innervation of arterioles and capillaries in the brain. Stroke, 8, 360-365. doi:10.1161/01.STR.8.3.360

[16] Si, M.L. and Lee, T.J. (2002) Alpha7-nicotinic acetylcholine receptors on cerebral perivascular sympathetic nerves mediate choline-induced nitrergic neurogenic vasodilation. Circulation Research, 91, 62-69. doi:10.1161/01.RES.0000024417.79275.23

[17] Naldini, A., Carney, D.H., Bocci, V., Klimpel, K.D. Asuncion, M., Soares, L.E. and Klimpel, G.R. (1993) Thrombin enhances $\mathrm{T}$ cell proliferative responses and cytokine production. Cellular Immunology, 147, 367-377. doi:10.1006/cimm.1993.1076

[18] Smith, D.B., Janmey, P.A., Herbert, T.J. and Lind, S.E. (1987) Quantitative measurement of plasma gelsolin and its incorporation into fibrin clots. The Journal of Laboratory and Clinical Medicine, 110, 189-195.

[19] Gong, Y., Xi, G.H., Keep, R.F., Hoff, J.T. and Hua, Y. (2005) Complement inhibition attenuates brain edema and neurological deficits induced by thrombin. Acta Neurochirurgica Supplementum, 95, 389-392. doi:10.1007/3-211-32318-X 79

[20] Sambrano, G.R., Weiss, E.J., Zheng, Y.W., Huang, W. and Coughlin, S.R. (2001) Role of thrombin signalling in platelets in haemostasis and thrombosis. Nature, 413, 74-78. doi:10.1038/35092573

[21] Archiniegas, E., Neves, C.Y., Candelle, D. and Cardier, J.E. (2004) Thrombin and its protease-activated receptor1 (PAR1) participate in the endothelial-mesenchymal transdifferentiation process. DNA and Cell Biology, 23, 815825. doi:10.1089/dna.2004.23.815

[22] Armstrong, M.T., Lee, D.Y. and Armstrong, P.B. (2000) Regulation of proliferation of the fetal myocardium. Developmental Dynamics, 219, 226-236. doi:10.1002/1097-0177(2000)9999:9999<::AID-DVDY1 049>3.3.CO;2-S

[23] Murakami, K., Ueno, A., Yamanouchi, K. and Kondo, T. (1995) Thrombin induces GRO alpha/MGSA production in human umbilical vein endothelial cells. Thrombosis Research, 79, 387-394. doi:10.1016/0049-3848(95)00127-D

[24] Moser, M. and Patterson, C. (2003) Thrombin and vascular development: A sticky subject. Arteriosclerosis, Thrombosis, and Vascular Biology, 23, 922-930. doi:10.1161/01.ATV.0000065390.43710.F2

[25] Luo, W., Wang, Y. and Reiser, G. (2005) Two types of protease-activated receptors (PAR-1 and PAR-2) mediate calcium signaling in rat retinal ganglion cells RGC-5. Brain Research, 1047, 159-167. doi:10.1016/j.brainres.2005.04.040

[26] Mann, K.G., Brummel, K. and Butenas, S. (2003) What is all that thrombin for? Journal of Thrombosis and Haemostasis, 1, 1504-1514. doi:10.1046/j.1538-7836.2003.00298.x

[27] Sutherland, C.J. and Schurman, J.R. (1987) Complications associated with warfarin prophylaxis in total knee arthroplasty. Clinical Orthopaedics \& Related Research, 219, 158-162.

[28] Goldsack, N.R., Chambers, R.C., Dabbagh, K., Laurent, G.J. (1998) Molecules in focus thrombin. International Journal of Biochemistry and Cell Biology, 30, 641-646. doi:10.1016/S1357-2725(98)00011-9

[29] Haas, S. (2002) Future potential indications for an oral thrombin inhibitor. Hamostaseologie, 22, 36-43.

[30] Hedner, U. (2002) General haemostatic agents-Fact or fiction? Pathophysiology Haemostasis Thrombosis, 32, 33-36. doi:10.1159/000057299

[31] Mahajan, V.B., Pai, K.S., Lau, A. and Cunningham, D.D. (2000) Creatine kinase, an ATP-generating enzyme, is re- 
quired for thrombin receptor signaling to the cytoskeleton. Proceedings of the National Academy of Sciences of the United States of America, 97, 12062-12067. doi:10.1073/pnas.97.22.12062

[32] Warkentin, T.E., Sikov, W.M. and Lillicrap, D.P. (1999) Multicentric warfarin-induced skin necrosis complicating heparin-induced thrombocytopenia. American Journal of Hematology, 62, 44-48. doi:10.1002/(SICI)1096-8652(199909)62:1<44::AID-AJ H7>3.0.CO;2-F

[33] Chinni, C., de Niese, M.R., Tew, D.J., Jenkins, A.L., Bottomley, S.P. and Mackie, E.J. (1999) Thrombin, a survival factor for cultured myoblasts. The Journal of. Biological Chemistry, 274, 9169-9174. doi:10.1074/jbc.274.14.9169

[34] Pagel, C.N., de Niese, M.R., Abraham, L.A., Chinni, C., Song, S.J., Pike, R.N. and Mackie, E.J. (2003) Inhibition of osteoblast apoptosis by thrombin. Bone, 337, 733-743. doi:10.1016/S8756-3282(03)00209-6

[35] Naldini, A., Carney, D.H., Pucci, A. and Carraro, F. (2002) Human alpha-thrombin stimulates proliferation of interferon-gamma differentiated, growth-arrested U937 cells, overcoming differentiation-related changes in expression of p21CIP1/WAF1 and cyclin D1. Journal of Cellular Physiology, 191, 290-297. doi:10.1002/jcp.10101

[36] Brass, L.F. and Molino, M. (1997) Protease-activated G protein-coupled receptors on human platelets and endothelial cells. Journal of Thrombosis and Haemostasis, 78, 234-241.

[37] Bretschneider, E., Kaufmann, R., Braun, M., Wittpoth, M., Glusa, E., Nowak, G. and Schror, K. (1999) Evidence for proteinase-activated receptor-2 (PAR-2)-mediated mitogenesis in coronary artery smooth muscle cells. British Journal of Pharmacology, 126, 1735-1740. doi:10.1038/sj.bjp.0702509

[38] Chalmers, C.J., Balmanno, K., Hadfield, K., Ley, R. and Cook, S.J. (2003) Thrombin inhibits Bim (Bcl-2-interacting mediator of cell death) expression and prevents serum-withdrawal-induced apoptosis via protease-actvated receptor 1. Biochemical Journal, 375, 99-109. doi:10.1042/BJ20030346

[39] Day, J.R., Taylor, K.M., Lidington, E.A., Mason, J.C., Haskard, D.O., Randi, A.M. and Landis, R.C. (2006) Aprotinin inhibits proinflammatory activation of endothelial cells by thrombin through the protease-activated receptor 1. The Journal of Thoracic and Cardiovascular Surgery, 131, 21-27. doi:10.1016/j.jtcvs.2005.08.050

[40] Gorbacheva, L.R., Storozhevykh, T.P., Kiseleva, E.V., Pinelis, V.G. and Strukova, S.M. (2005) Proteinase activated type 1 receptors are involved in the mechanism of protection of rat hippocampal neurons from glutamate toxicity. Bulletin of Experimental Biology and Medicine, 140, 285-288. doi:10.1007/s10517-005-0468-y

[41] Wang, K.Y., Chang, F.H., Jeng, J. H., Hou, L.T., Chen, K.C. and Kuo, M.Y. (2000) Expression of functional type 1 protease-activated thrombin receptors by mouse primary palatal mesenchymal cells in vitro. Archives of Oral Biology, 45, 819-825. doi:10.1016/S0003-9969(00)00060-1
[42] Wang, H. and Reiser, G. (2003) Thrombin signaling in the brain: The role of protease-activated receptors. Biological Chemistry, 384, 193-202. doi:10.1515/BC.2003.021

[43] Song, S.J., Pagel, C.N., Campbell, T.M., Pike, R.N. and Mackie, E.J. (2005) The role of protease-activated recaptor-1 in bone healing. The American Journal of Pathology, 166, 857-868. doi:10.1016/S0002-9440(10)62306-1

[44] Kaushal, V., Kaushal, G.P., Melkaveri, S.N. and Mehta, P. (2004) Thalidomide protects endothelial cells from doxorubicin-induced apoptosis but alters cell morphology. Journal of Thrombosis and Haemostasis, 2, 327-334. doi:10.1046/j.1538-7933.2003.00573.X

[45] Zania, P., Kritikou, S., Flordellis, C.S., Maragoudakis, M.E. and Tsopanoglou, N.E. (2006) Blockade of angiogenesis by small molecule antagonists to protease-activated recaptor-1 (PAR-1): Association with endothelial cell growth suppression and induction of apoptosis. The Journal of Pharmacology and Experimental Therapeutics, 318, 246254. doi:10.1124/jpet.105.099069

[46] Fuentes, A., Rojas, A., Porter, K.B., Saviello, G. and O'Brien, W.F. (1995) The effect of magnesium sulfate on bleeding time in pregnancy. American Journal of Obstetrics Gynecology, 173, 1246-1249. doi:10.1016/0002-9378(95)91363-7

[47] Garcia, J.G., Pavalko, F.M. and Patterson, C.E. (1995) Vascular endothelial cell activation and permeability responses to thrombin. Blood Coagulation \& Fibrinolysis, 6, 609-626. doi:10.1097/00001721-199510000-00001

[48] Jeng, J.H., Chan, C.P., Wu, H.L., Ho, Y.S., Lee, J.J., Liao, C.H., Chang, Y.K., Chang, H.H., Chen, Y.J., Perng, P.J. and Chang, M.C. (2004) Protease-activated receptor-1induced calcium signaling in gingival fibroblasts is mediated by sarcoplasmic reticulum calcium release and extracellular calcium influx. Cellular Signalling, 16, 731740. doi:10.1016/j.cellsig.2003.11.008

[49] James, M.F. and Roche, A.M. (2004) Dose-response relationship between plasma ionized calcium concentration and thrombelastography. Journal of Cardiothoracic and Vascular Anesthesia, 18, 581-586. doi:10.1053/j.jvca.2004.07.016

[50] Shapiro, M.J. and Mistry, B. (1996) Calcium regulation and nonprotective properties of calcium in surgical isch mia. New Horizon, 4, 134-138.

[51] Bobe, R., Yin, X., Roussanne, M.C., Stepien, O., Polidan, E., Faverdin, C. and Marche, P. (2003) Evidence for ERK1/2 activation by thrombin that is independent of EGFR transactivation. American Journal of Physiology, Heart and Circulatory Physiology, 285, H745-H754.

[52] Brass, E.P., Forman, W.B., Edwards, R.V. and Lindan, O. (1978) Fibrin formation: Effect of calcium ions. Blood, 52, 654-658.

[53] Brostrom, M.A., Pan, Z., Meiners, S., Drumm, C., Ahmed, I. and Brostrom, C.O. (2003) $\mathrm{Ca}^{2+}$ dynamics of thrombin-stimulated rat heart-derived embryonic myocytes: Relationship to protein synthesis and cell growth. The International Journal of Biochemistry \& Cell Biology, 35, 1573-1587. doi:10.1016/S1357-2725(03)00132-8

[54] Butenas, S., Brummel, K.E., Paradis, S.G. and Mann, 
K.G. (2003) Influence of factor VIIa and phospholipids on coagulation in "acquired" hemophilia. Arteriosclerosis, Thrombosis, and Vascular Biology, 23, 123-129. doi:10.1161/01.ATV.0000042081.57854.A2

[55] Davies, M.S., Flannery, M.C. and McCollum, C.N. (1997) Calcium alginate as haemostatic swabs in hip fracture surgery. Journal of the Royal College of Surgeons of Edinburgh, 42, 31-32.

[56] Gurrieri, M.A. (1990) Thrombin-fibrinogen interaction: Release of fibrinopeptides and the effects of ATP. Medicina (Firenze), 10, 51-52.

[57] Murdoch, I.A., Qureshi, S.A. and Huggon, I.C. (1994) Perioperative haemodynamic effects of an intravenous infusion of calcium chloride in children following cardiac surgery. Acta Paediatrica, 83, 658-661. doi:10.1111/j.1651-2227.1994.tb13103.x

[58] Sakariassen, K.S., Ottenhof-Rovers, M. and Sixma, J.J. (1984) Factor VIII-von Willebrand factor requires calcium for facilitation of platelet adherence. Blood, 63, 996-103.

[59] Sakata, Y. and Aoki, N. (1980) Cross-linking of alpha 2-plasmin inhibitor to fibrin by fibrin-stabilizing factor. The journal of Clinical Investigation, 65, 290-297. doi:10.1172/JCI109671

[60] Von Brecht, J.H., Flanigan, M.J., Freeman, R.M. and Lim, V.S. (1986) Regional anticoagulation: hemodialysis with hypertonic trisodium citrate. American Journal of Kidney Diseases, 8, 196-201.

[61] Zuccala, G., Pahor, M., Landi, F., Gasparini, G., Pagano, F., Carbonin, P. and Cocchi, A. (1997) Use of calcium antagonists and need for perioperative transfusion in older patients with hip fracture: Observational study. British Medical Journal, 314, 643-644. doi:10.1136/bmj.314.7081.643

[62] Zuccala, G., Pedone, C., Cocchi, A., Pahor, M., Carosella, L., Carbonin, P., Bernabei, R. and Gruppo Italiano di Farmacoepidemiologia nell'Anziano (GIFA) investigators (2000) Use of calcium antagonists and hemoglobin loss in hospitalized elderly patients: A cohort study. Clinical Pharmacology \& Therapeutics, 67, 314-322. doi:10.1067/mcp.2000.104787

[63] Barbagallo, M., Dominguez, L.J. and Resnick, L.M. (2007) Magnesium metabolism in hypertension and type 2 diabetes mellitus. American Journal of Therapeutics, 14, 375-385. doi:10.1097/01.mjt.0000209676.91582.46

[64] Baker, S.B. and Worthley, L.I. (2002) The essentials of calcium, magnesium and phosphate metabolism: Part II. Disorders. Critical Care and Resuscitation, 4, 307-315.

[65] Baker, S.B. and Worthley, L.I. (2002) The essentials of calcium, magnesium and phosphate metabolism: Part I. Physiology. Critical Care and Resuscitation, 4, 301-306.

[66] James, M.F. and Cronje, L. (2004) Pheochromocytoma crisis: The use of magnesium sulfate. Anesthesia \& Analgesia, 99, 680-686. doi:10.1213/01.ANE.0000133136.01381.52

[67] Dedhia, H.V. and Banks, D.E. (1994) Pulmonary response to hyperoxia: Effects of magnesium. Environmental Health Perspectives, 102, 101-105.
[68] Elsharnouby, N.M. and Elsharnouby, M.M. (2006) Magnesium sulphate as a technique of hypotensive anaesthesia. British Journal of Anaesthesia, 96, 727-731. doi:10.1093/bja/ael085

[69] Elin, R.J. (1988) Magnesium metabolism in health and disease. Disease-a-Month, 34, 161-218. doi:10.1016/0011-5029(88)90013-2

[70] Erodi, A. (1973) Magnesium-An anticoagulant physiological electrolyte. Medizinische Klinik, 68, 216-219.

[71] Fehlinger, R., Mielke, U., Fauk, D. and Seidel, K. (1986) Rheographic indications for reduced cerebral vasoconstriction after oral magnesium medication in tetanic patients, a double-blind, placebo-controlled trial. Magnesium, 5, 60-65.

[72] Galland, L. (1991) Magnesium, stress and neuropsychiatric disorders. Magnesium and Trace Elements, 10, $287-$ 301.

[73] Kondo, H., Kobayashi, E., Itani, T., Tatsumi, N. and Tsuda, I. (2002) Hematology tests of blood anticoagulated with magnesium sulphate. Southeast Asian Journal of Tropical Medicine and Public Health, 33, 6-9.

[74] Menzel, R., Pusch, H., Ratzmann, G.W., Besch, W., Forster, F., Albrecht, G. and Ruhnke, R. (1985) Serum magnesium in insulin-dependent diabetics and healthy subjects in relation to insulin secretion and glycemia during glucose-glucagon test. Experimental and Clinical Endocrinology \& Diabetes, 85, 81-88. doi:10.1055/s-0029-1210423

[75] Mussoni, L., Sironi, L., Tedeschi, L., Calvio, A.M., Colli, S. and Tremoli, E. (2001) Magnesium inhibits arterial thrombi after vascular injury in rat: In vivo impairment of coagulation. Thrombosis and Haemostasis, 86, 1292-1295.

[76] Rukshin, V., Shah, P.K., Cercek, B., Finkelstein, A., Tsang, V. and Kaul, S. (2002) Comparative antithrombotic effects of magnesium sulfate and the platelet glycoprotein IIb/IIIa inhibitors tirofiban and eptifibatide in a canine model of stent thrombosis. Circulation, 105, 1970-1975. doi:10.1161/01.CIR.0000014612.88433.62

[77] Scheibe, F., Haupt, H. and Vlastos, G.A. (2000) Preventive magnesium supplement reduces ischemia-induced hearing loss and blood viscosity in the guinea pig. European Archives of Oto-Rhino-Laryngology, 257, 355-361. doi:10.1007/s004050000252

[78] Seelig, M.S. (1990) Increased need for magnesium with the use of combined oestrogen and calcium for osteoporosis treatment. Magnesium Research, 3, 197-215.

[79] Karp, J.M., Tanaka, T.S., Zohar, R., Sodek, J., Shoichet, M.S., Davies, J.E. and Stanford, W.L. (2005) Thrombin mediated migration of osteogenic cells. Bone, 37, 337348. doi:10.1016/j.bone.2005.04.022

[80] Sabri, A., Muske, G., Zhang, H., Pak, E., Darrow, A., Andrade-Gordon, P. and Steinberg, S.F. (2000) Signaling properties and functions of two distinct cardiomyocyte protease-activated receptors. Circulation Research, 86, 1054-1061. doi:10.1161/01.RES.86.10.1054

[81] Tantivejkul, K., Loberg, R.D., Mawocha, S.C., Day, L.L., John, L.S., Pienta, B.A., Rubin, M.A. and Pienta, K.J. (2005) PAR1-mediated NFkappaB activation promotes 
survival of prostate cancer cells through a Bcl-xL-dependent mechanism. Journal of Cellular Biochemistry, 96, 641-652. doi:10.1002/jcb.20533

[82] Fenton, J.W., Ofosu, F.A., Brezniak, D.V. and Hassouna, H.I. (1998) Thrombin and antithrombotics. Semin Thrombosis Hemostasis, 24, 87-91. doi:10.1055/s-2007-995828

[83] Stewart, A.J., Penman, I.D., Cook, M.K. and Ludlam, C.A. (1999) Warfarin-induced skin necrosis. Postgraduate Medical Journal, 75, 233-235.

[84] Brummel, K.E., Paradis, S.G., Butenas, S. and Mann, K.G. (2002) Thrombin functions during tissue factor-induced blood coagulation. Blood, 100, 148-152. doi:10.1182/blood.V100.1.148

[85] Hong, S.L. and Levine, L. (1976) Stimulation of prostaglandin synthesis by bradykinin and thrombin and their mechanisms of action on MC5-5 fibroblasts. The Journal of Bioloogical Chemistry., 251, 5814-5816.

[86] Pohl, J., Bruhn, H.D. and Christophers, E. (1979) Thrombin and fibrin-induced growth of fibroblasts: Role in wound repair and thrombus organization. Journal of Molecular Medicine, 57, 273-277. doi:10.1007/BF01476508

[87] Wang, H. and Reiser, G. (2003) The role of the $\mathrm{Ca}^{2+}$ sensitive tyrosine kinase Pyk2 and Src in thrombin signalling in rat astrocytes. Journal of Neurochemistry, 84, 1349-1357. doi:10.1046/j.1471-4159.2003.01637.x

[88] Imamura, T. (2004) Tissue factor expression at the site of inflammation: A cross-talk between inflammation and the blood coagulation system. Rinsho byori, The Japanese Journal of Clinical Pathology, 52, 342-349.

[89] Glembotski, C.C., Irons, C.E., Krown, K.A., Murray, S.F., Sprenkle, A.B. and Sei, C.A. (1993) Myocardial alphathrombin receptor activation induces hypertrophy and increases atrial natriuretic factor gene expression. The Journal of Biological Chemistry, 268, 20646-20652.

[90] Okada, M., Suzuki, K., Takada, K., Nakashima, M., Nakanishi, T. and Shinohara, T. (2005) Detection of up-regulated genes in thrombin-stimulated human umbilical vein endothelial cells. Thrombosis Research, 118, 715721.

[91] Rothman, A., Wolner, B., Button, D. and Taylor, P. (1994) Immediate-early gene expression in response to hypertrophic and proliferative stimuli in pulmonary arterial smooth muscle cells. The Journal of Biological Chemistry, 269, 6399-6404.

[92] Tsopanoglou, N.E. and Maragoudakis, M.E. (1998) On the mechanism of thrombin-induced angiogenesis: Inhibition of attachment of endothelial cells on basement membrane components. Angiogenesis, 1, 192-200. doi:10.1023/A:1018381822011

[93] Hornstra, G. and Hemker, H.C. (1979) Clot-promoting effect of platelet-vessel wall interaction: Influence of dietary fats and relation to arterial thrombus formation in rats. Haemostasis, 8, 211-226.

[94] Hornstra, G. (1981) Platelet-vessel wall interaction: Role of blood clotting. Philosophical Transactions of the Royal Society B: Biological Sciences, 294, 355-371. doi:10.1098/rstb.1981.0112
[95] Henriksen, R.A., Samokhin, G.P. and Tracy, P.B. (1997) Thrombin-induced thromboxane synthesis by human platelets. Properties of anion binding exosite I-independent receptor. Arteriosclerosis, Thrombosis, and Vascular Biology, 17, 3519-3526. doi:10.1161/01.ATV.17.12.3519

[96] Tate, B.F. and Rittenhouse, S.E. (1993) Thrombin activation of human platelets causes tyrosine phosphorylation of PLC-gamma 2. Biochimica et Biophysica Acta, 1178, 281-285. doi:10.1016/0167-4889(93)90205-4

[97] Asero, R., Tedeschi, A., Riboldi, P. and Cugno, M. (2006) Plasma of patients with chronic urticaria shows signs of thrombin generation, and its intradermal injection causes wheal-and-flare reactions much more frequently than autologous serum. The Journal of Allergy and Clinical Immunology, 117, 1113-1117. doi:10.1016/j.jaci.2005.12.1343

[98] Naldini, A., Morena, E., Filippi, I., Pucci, A., Bucci, M., Cirino, G. and Carraro, F. (2006) Thrombin inhibits IFNgamma production in human peripheral blood mononuclear cells by promoting a Th2 profile. Journal of Interferon \& Cytokine Research, 26, 793-799. doi:10.1089/jir.2006.26.793

[99] Naldini, A., Bernini, C., Pucci, A. and Carraro, F. (2005) Thrombin-mediated IL-10 up-regulation involves protease-activated receptor (PAR)-1 expression in human mononuclear leukocytes. Journal of Leukocyte Biology, 78, 736-744. doi:10.1189/jlb.0205082

[100] Naldini, A., Carraro, F., Baldari, C.T., Paccani, S.R., Bernini, C., Keherly, M.J. and Carney, D.H. (2004) The thrombin peptide, TP508, enhances cytokine release and activates signaling events. Peptides, 25, 1917-1726. doi:10.1016/j.peptides.2004.05.017

[101] Naldini, A., Aarden, L., Pucci, A., Bernini, C. and Carraro, F. (2003) Inhibition of interleukin-12 expression by alpha-thrombin in human peripheral blood mononuclear cells: A potential mechanism for modulating Th1/Th2 responses. British Journal of Pharmacology, 140, 980-986. doi:10.1038/sj.bjp.0705514

[102] Naldini, A., Pucci, A., Carney, D.H., Fanetti, G. and Carraro, F. (2002) Thrombin enhancement of interleukin1 expression in mononuclear cells: Involvement of proteinase-activated receptor-1. Cytokine, 20, 191-199. doi:10.1006/cyto.2002.2001

[103] Naldini, A., Carney, D.H., Pucci, A., Pasquali, A. and Carraro, F. (2000) Thrombin regulates the expression of proangiogenic cytokines via proteolytic activation of protease-activated receptor-1. General Pharmacology the Vascular System, 35, 255-259. doi:10.1016/S0306-3623(01)00113-6

[104] Naldini, A., Sower, L., Bocci, V., Meyers, B. and Carney, D.H. (1998) Thrombin receptor expression and responsiveness of human monocytic cells to thrombin is linked to interferon-induced cellular differentiation. Journal of Cellular Physiology, 177, 76-84. doi:10.1002/(SICI)1097-4652(199810)177:1<76::AID-JC P8>3.0.CO;2-B

[105] Ben Amor, N., Pariente, J.A., Salido, G.M., Bartegi, A. and Rosado, J.A. (2005) Caspases 3 and 9 are translocated to the cytoskeleton and activated by thrombin in 
human platelets. Evidence for the involvement of PKC and the actin filament polymerization. Cellular Signalling, 18, 1252-1261.

[106] Ueno, A., Murakami, K., Yamanouchi, K., Watanabe, M. and Kondo, T. (1996) Thrombin stimulates production of interleukin-8 in human umbilical vein endothelial cells. Immunology, 88, 76-81. doi:10.1046/j.1365-2567.1996.d01-635.x

[107] Hua, Y., Keep, R.F., Schallert, T., Hoff, J.T. and Xi, G. (2003) A thrombin inhibitor reduces brain edema, glioma mass and neurological deficits in a rat glioma model. Acta Neurochirurgica. Supplementum, 86, 503-506. doi:10.1007/978-3-7091-0651-8_103

[108] Howell, D.C., Goldsack, N.R., Marshall, R.P., McAnulty, R.J., Starke, R., Purdy, G., Laurent, G.J. and Chambers, R.C. (2001) Direct thrombin inhibition reduces lung collagen, accumulation, and connective tissue growth factor mRNA levels in bleomycin-induced pulmonary fibrosis. American Journal of Pathology, 159, 1383-1395. doi:10.1016/S0002-9440(10)62525-4

[109] Howells, G.L., Macey, M., Curtis, M.A. and Stone, S.R. (1993) Peripheral blood lymphocytes express the platelet-type thrombin receptor. British Journal of Haematology, 84, 156-160. doi:10.1111/j.1365-2141.1993.tb03039.x

[110] Tordai, A., Fenton 2nd, J.W., Andersen, T. and Gelfand, E.W. (1993) Functional thrombin receptors on human T lymphoblastoid cells. The Journal of Immunology, 150, 4876-4886.

[111] Naldini, A. and Carney, D.H. (1996) Thrombin modulation of natural killer activity in human peripheral lymphocytes. Cellular Immunology, 172, 35-42. doi:10.1006/cimm.1996.0212

[112] Huang, Y.Q., Li, J.J. and Karpatkin, S. (2000) Thrombin inhibits tumor cell growth in association with up-regulation of $\mathrm{p}^{2} 1^{\text {waf/cip1 }}$ and caspases via a p53-independent, STAT-1-dependent pathway. Journal of Biological Chemistry, 275, 6462-6468. doi:10.1074/jbc.275.9.6462

[113] Kuznik, B.I., Malezhik, L.P., Al'fonov, V.V. and Mamedov Ia, Z. (1985) Effect of thrombin on macrophage and lymphocyte functional activity. Bulletin of Experimental Biology and Medicine, 99, 597-598. doi:10.1007/BF00837291

[114] Tran, T. and Stewart, A.G. (2003) Protease-activated receptor (PAR)-independent growth and pro-inflammatory actions of thrombin on human cultured airway smooth muscle. British Journal of Pharmacology, 138, 865-875. doi:10.1038/sj.bjp.0705106

[115] Vlahos, R., Lee, K.S., Guida, E., Fernandes, D.J., Wilson, J.W. and Stewart, A.G. (2003) Differential inhibition of thrombin-and EGF-stimulated human cultured airway smooth muscle proliferation by glucocorticoids. Pulmonary Pharmacology \& Therapeutics, 16, 171-180. doi:10.1016/S1094-5539(02)00183-9

[116] Laudes, I.J., Chu, J.C., Sikranth, S., Huber-Lang, M., Guo, R.F., Riedemann, N., Sarma, J.V., Schmaier, A.H. and Ward, P.A. (2002) Anti-c5a ameliorates coagulation/ fibrinolytic protein changes in a rat model of sepsis. The
American Journal of Pathology, 160, 1867-1875. doi:10.1016/S0002-9440(10)61133-9

[117] Holm, B., Nilsen, D.W., Kierulf, P. and Godal, H.C. (1985) Purification and characterization of 3 fibrinogens with different molecular weights obtained from normal human plasma. Thrombosis Research, 37, 165-176. doi:10.1016/0049-3848(85)90043-X

[118] Bouma, B.N. and Mosnier, L.O. (2006) Thrombin activatable fibrinolysis inhibitor (TAFI) - How does thrombin regulate fibrinolysis? Annals of Medicine, 38, 378388. doi:10.1080/07853890600852898

[119] Brass, E.P., Forman, W.B., Edwards, R.V. and Lindan, O. (1976) Fibrin formation: The role of the fibrinogen-fibrin monomer complex. Journal of Thrombosis and Haemostasis, 36, 37-48.

[120] Brummel, K.E., Butenas, S. and Mann, K.G. (1999) An integrated study of fibrinogen during blood coagulation. Journal of Biological Chemistry, 274, 22862-22870. doi:10.1074/jbc.274.32.22862

[121] Butenas, S. and Mann, K.G. (2002) Blood coagulation. Biochemistry (Moscow), 67, 3-12. doi:10.1023/A:1013985911759

[122] Juhan-Vague, I. and Hans, M. (2003) From fibrinogen to fibrin and its dissolution. Bulletin de l Academie Nationale de Medecine, 187, 69-82; discussion 83-84.

[123] Mosesson, M.W. (2005) Fibrinogen and fibrin structure and functions. Journal of Thrombosis and Haemostasis, 3, 1894-1904. doi:10.1111/j.1538-7836.2005.01365.x

[124] Malik, A.B. (1987) Role of fibrin-neutrophil interactions in lung vascular injury. Progress in Clinical and Biological Research, 236A, 33-42.

[125] Weisel, J.W. (2005) Fibrinogen and fibrin. Advances in Protein Chemistry, 70, 247-299. doi:10.1016/S0065-3233(05)70008-5

[126] Stasko, J., Hudecek, J. and Kubisz, P. (2004) Thrombin activatable fibrinolysis inhibitor (TAFI) and its importance in the regulation of fibrinolysis. Vnitrni Lekarstvi, 50, 36-44.

[127] Castellino, F.J. (1981) Recent Advances in the Chemistry of Fibrinolytic system. Chemical Reviews, 81, 431-446. doi:10.1021/cr00045a001

[128] Castoldi, E. and Rosing, J. (2004) Factor V Leiden: A disorder of factor $\mathrm{V}$ anticoagulant function. Current Opinion in Hematology, 11, 176-181. doi:10.1097/01.moh.0000130315.41033.32

[129] Walsh, P.N. and Ahmad, S.S. (2002) Proteases in blood clotting. Essays in Biochemistry, 38, 95-111.

[130] Augustin, H.G., Braun, K., Telemenakis, I., Modlich, U. and Kuhn, W. (1995) Ovarian angiogenesis. Phenotypic characterization of endothelial cells in a physiological model of blood vessel growth and regression. The American Journal of Pathology, 147, 339-351.

[131] Birkenbach, M., Josefsen, K., Yalamanchili, R., Lenoir, G. and Kieff, E. (1993) Epstein-Barr virus-induced genes: First lymphocyte-specific $\mathrm{G}$ protein-coupled peptide receptors. Journal of Virology, 67, 2209-2220.

[132] Suo, Z., Wu, M., Citron, B.A., Gao, C. and Festoff, B.W. 
(2003) Persistent protease-activated receptor 4 signaling mediates thrombin-induced microglial activation. Journal of Biological Chemistry, 278, 31177-31183. doi:10.1074/jbc.M302137200

[133] Zain, J., Huang, Y.Q., Feng, X., Nierodzik, M.L., Li, J.J. and Karpatkin, S. (2000) Concentration-dependent dual effect of thrombin on impaired growth/apoptosis or mitogenesis in tumor cells. Blood, 95, 3133-3138.

[134] Tsopanoglou, N.E. and Maragoudakis, M.E. (2004) Role of thrombin in angiogenesis and tumor progression. Seminars in Thrombosis and Hemostasis, 30, 63-69. doi:10.1055/s-2004-822971

[135] Choi, S.H., Lee, D.Y., Ryu, J.K., Kim, J., Joe, E.H. and Jin, B.K. (2003) Thrombin induces nigral dopaminergic neurodegeneration in vivo by altering expression of death-related proteins. Neurobiology of Disease, 14, 181193. doi:10.1016/S0969-9961(03)00085-8

[136] Turgeon, V.L., Lloyd, E.D., Wang, S., Festoff, B.W. and Houenou, L.J. (1998) Thrombin perturbs neurite outgrowth and induces apoptotic cell death in enriched chick spinal motoneuron cultures through caspase activation. The Journal of Neuroscience, 18, 6882-6891.

[137] Uprichard, J. and Perry, D.J. (2002) Factor X deficiency. Blood Reviews, 16, 97-110. doi:10.1054/blre.2002.0191

[138] Schiller, H., Bartscht, T., Arlt, A., Zahn, M.O., Seifert, A., Bruhn, T., Bruhn, H.D. and Gieseler, F. (2002) Thrombin as a survival factor for cancer cells: Thrombin activation in malignant effusions in vivo and inhibition of idarubicin-induced cell death in vitro. International Journal of Clinical Pharmacology and Therapeutics, 40, 329-335.

[139] Idell, S. (2002) Adult respiratory distress syndrome: Do selective anticoagulants help? American Journal of Respiratory Medicine, 1, 383-391.

[140] Bredbacka, S. and Edner, G. (1994) Soluble fibrin and D-dimer as detectors of hypercoagulability in patients with isolated brain trauma. Journal of Neurosurgical Anesthesiology, 6, 75-82.

[141] Bredbacka, S., Blomback, M. and Wiman, B. (1994) Soluble fibrin: A predictor for the development and outcome of multiple organ failure. American Journal of Hematology, 46, 289-294. doi:10.1002/ajh.2830460407

[142] Lip, G.Y., Blann, A.D., Zarifis, J., Beevers, M., Lip, P.L. and Beevers, D.G. (1995) Soluble adhesion molecule P-selectin and endothelial dysfunction in essential hypertension: Implications for atherogenesis? A preliminary report. Journal of Hypertension, 13, 1674-1678.

[143] Plendl, H., Caliebe, A. and Grote, W. (2002) Molecular variants of fibrinogen. Hamostaseologie, 22, 36-41.

[144] Idell, S. (2002) Endothelium and disordered fibrin turnover in the injured lung: Newly recognized pathways. Critical Care Medicine, 30, S274-S280. doi:10.1097/00003246-200205001-00017

[145] Gartner, H.V. (1994) Nephropathy in pregnancy-An endothelial lesion? Zentralblatt fur Gynakologie, 116, 123-137.

[146] Kawada, H., Katsura, H., Kamimura, M., Toyoda, E. and Kudo, K. (2003) Coagulation activity in the airways of asthmatic patients. Nihon Kokyuki Gakkai Zasshi, 41,
620-625.

[147] Widdicombe, J.G. (1992) Asthma. Tracheobronchial vasculature. British Medical Bullitin, 48, 108-119.

[148] Fan, J., Kapus, A., Li, Y.H., Rizoli, S., Marshall, J.C. and Rotstein, O.D. (2000) Priming for enhanced alveolar fibrin deposition after hemorrhagic shock: Role of tumor necrosis factor. American Journal of Respiratory Cell and Molecular Biology, 22, 412-421.

[149] Akassoglou, K., Akpinar, P., Murray, S. and Strickland, S. (2003) Fibrin is a regulator of Schwann cell migration after sciatic nerve injury in mice. Neuroscience Letters, 338, 185-188. doi:10.1016/S0304-3940(02)01387-3

[150] Akassoglou, K., Yu, W.M., Akpinar, P. and Strickland, S. (2002) Fibrin inhibits peripheral nerve remyelination by regulating Schwann cell differentiation. Neuron, 33, 861875. doi:10.1016/S0896-6273(02)00617-7

[151] Akassoglou, K. and Strickland, S. (2002) Nervous system pathology: The fibrin perspective. Biological Chemistry, 383, 37-45. doi:10.1515/BC.2002.004

[152] Akassoglou, K., Kombrinck, K.W., Degen, J.L. and Strickland, S. (2000) Tissue plasminogen activator-mediated fibrinolysis protects against axonal degeneration and demyelination after sciatic nerve injury. The Journal of Cell Biology, 149, 1157-1166. doi:10.1083/jcb.149.5.1157

[153] Bredbacka, S., Blomback, M., Hagnevik, K., Irestedt, L. and Raabe, N. (1986) Per-and postoperative changes in coagulation and fibrinolytic variables during abdominal hysterectomy under epidural or general anaesthesia. Acta Anaesthesiologica Scandinavica, 30, 204-210. doi:10.1111/j.1399-6576.1986.tb02397.x

[154] Fairley, J.K., Owen, J.E. and Birch, D.F. (1983) Protein composition of urinary casts from healthy subjects and patients with glomerulonephritis. British Medical Journal (Clinical Research Edition), 287, 1838-1840. doi:10.1136/bmj.287.6408.1838

[155] Ventura, J.E., Villa, M., Mizraji, R. and Ferreiros, R. (1997) Acute renal failure in pregnancy. Renal Failure, 19, 217-220. doi:10.3109/08860229709026279

[156] Rath, W., Faridi, A. and Dudenhausen, J.W. (2000) HELLP syndrome. Journal of Perinatal Medicine, 28, 249-260. doi:10.1515/JPM.2000.033

[157] Tighe, D., Moss, R., Boghossian, S., Heath, M.F., Chessum, B. and Bennett, E.D. (1989) Multi-organ damage resulting from experimental faecal peritonitis. Clinical Science, 76, 269-276.

[158] Rodriguez-Inigo, E., Bartolome, J., Quiroga, J.A., Hedner, U., Suarez, A., Tomas, J.F., Manzarbeitia, F., Arocena, C., Manzano, M.L., Oliva, H. and Carreno, V. (2001) Expression of factor VII in the liver of patients with liver disease: Correlations with the disease severity and impairment in the hemostasis. Blood Coagulation \& Fibrinolysis, 12, 193-199.

doi:10.1097/00001721-200104000-00005

[159] Fiorucci, S., Antonelli, E., Distrutti, E., Severino, B., Fiorentina, R., Baldoni, M., Caliendo, G., Santagada, V., Morelli, A. and Cirino, G. (2004) PAR1 antagonism protects against experimental liver fibrosis. Role of proteinase receptors in stellate cell activation. Hepatology, 


\section{9, 365-735. doi:10.1002/hep.20054}

[160] Schoots, I.G., Levi, M., van Vliet, A.K., Declerck, P.J., Maas, A.M. and van Gulik, T.M. (2004) Enhancement of endogenous fibrinolysis does not reduce local fibrin deposition, but modulates inflammation upon intestinal ischemia and reperfusion. Journal of Thrombosis and Haemostasis, 91, 497-505.

[161] Kawasaki, J., Katori, N., Kodaka, M., Miyao, H. and Tanaka, K.A. (2004) Electron microscopic evaluations of clot morphology during thrombelastography. Anesthesia \& Analgesia, 99, 1440-1444. doi:10.1213/01.ANE.0000134805.30532.59

[162] Dargaud, Y., Beguin, S., Lienhart, A., Al Dieri, R., Trzeciak, C., Bordet, J.C., Hemker, H.C. and Negrier, C. (2005) Evaluation of thrombin generating capacity in plasma from patients with haemophilia A and B. Thrombosis and Haemostasis, 93, 475-480.

[163] Dufner, G.S. and Marbet, G.A. (2002) Factor XIII in man: A review. Hamostaseologie, 22, 11-19.

[164] Nielsen, V.G., Gurley, W.Q. Jr., and Burch, T.M. (2004) The impact of factor XIII on coagulation kinetics and clot strength determined by thrombelastography. Anesthesia \& Analgesia, 99, 120-123. doi:10.1213/01.ANE.0000123012.24871.62

[165] Goudemand, M. (1983) Plasma fibronectin. Revue Française de Transfusion et Immuno-Hématologie, 26, 279298. doi:10.1016/S0338-4535(83)80032-4

[166] He, S., Blomback, M., Jacobsson Ekman, G. and Hedner, U. (2003) The role of recombinant factor VIIa (FVIIa) in fibrin structure in the absence of FVIII/FIX. Journal of Thrombosis and Haemostasis, 1, 1215-1219. doi:10.1046/j.1538-7836.2003.00242.x

[167] McIntosh, J.H., Owens, D., Lee, C.A., Raut, S. and Barrowcliffe, T.W. (2003) A modified thrombin generation test for the measurement of factor VIII concentrates. Journal of Thrombosis and Haemostasis, 1, 1005-1011. doi:10.1046/j.1538-7836.2003.00209.x

[168] Vehar, G.A. and Davie, E.W. (1977) Formation of a serine enzyme in the presence of bovine factor VIII (antihemophilic factor) and thrombin. Science, 197, 374-376. doi:10.1126/science.877560

[169] Wettstein, P., Haeberli, A., Stutz, M., Rohner, M., Corbetta, C., Gabi, K., Schnider, T. and Korte, W.J. (2004) Decreased factor XIII availability for thrombin and early loss of clot firmness in patients with unexplained intraoperative bleeding. Anesthesia \& Analgesia, 99, 15641569. doi:10.1213/01.ANE.0000134800.46276.21

[170] Wilmer, M., Schroder, V. and Kohler, H.P. (2002) Methods for the determination of factor XIII/XIIIa. Hamostaseologie, 22, 32-42.

[171] Holemans, R. (1965) Enhancement of fibrinolysis in the dog by injection of vasoactive drugs. American Journal of Physiological, 208, 511-520.

[172] Tamaki, T. and Aoki, N. (1981) Cross-linking of alpha 2-plasmin inhibitor and fibronectin to fibrin by fibrinstabilizing factor. Biochimica et Biophysica Acta, 661, 280-286. doi:10.1016/0005-2744(81)90016-4

[173] Willert, H.G., Horrig, C., Ewald, W.and Scharrer, I. (1983)
Orthopaedic surgery in hemophilic patients. Archives of Orthopaedic and Trauma Surgery, 101, 121-132. doi:10.1007/BF00433272

[174] Markakis, P., Papajoannou, N., Kambouruglou, G. (1984) Fractures in hemophilia patients. Unfallchirurgie, 10, 173-176. doi:10.1007/BF02585724

[175] Roberts, J.M., Taylor, R.N., Musci, T.J., Rodgers, G.M., Hubel, C.A. and McLaughlin, M.K. (1989) Preeclampsia: An endothelial cell disorder. American Journal of Obstetrics and Gynecology, 161, 1200-1204.

[176] Malyszko, J., Suchowierska, E., Malyszko, J.S. and Mysliwiec, M. (2002) A comprehensive study on hemostasis in CAPD patients treated with erythropoietin. Journal of the International Society for Peritoneal Dialysis, 22, 582-592.

[177] Antovic, J.P., Antovic, A., He, S., Tengborn, L. and Blomback, M. (2002) Overall haemostatic potential can be used for estimation of thrombin-activatable fibrinolysis inhibitor-dependent fibrinolysis in vivo and for possible follow-up of recombinant factor VIIa treatment in patients with inhibitors to factor VIII. Haemophilia, 8, 781786. doi:10.1046/j.1365-2516.2002.00689.x

[178] Lisman, T., Bijsterveld, N.R., Adelmeijer, J., Meijers, J. C., Levi, M., Nieuwenhuis, H.K. and De Groot, P.G. (2003) Recombinant factor VIIa reverses the in vitro and ex vivo anticoagulant and profibrinolytic effects of fondaparinux. Journal of Thrombosis and Haemostasis, 1, 2368-2373. doi:10.1046/j.1538-7836.2003.00536.x

[179] Malyszko, J., Malyszko, J.S., Hryszko, T. and Mysliwiec, M. (2006) Thrombin activatable fibrinolysis inhibitor in hypertensive kidney transplant recipients. Transplantation Proceedings, 38, 105-107. doi:10.1016/j.transproceed.2005.11.072

[180] Grunewald, M., Siegemund, A., Grunewald, A., Konegan, A., Koksch, M. and Griesshammer, M. (2002) Paradoxical hyperfibrinolysis is associated with a more intensely haemorrhagic phenotype in severe congenital haemophilia. Haemophilia, 8, 768-775. doi:10.1046/j.1365-2516.2002.00686.x

[181] Setian, N., Tanaka, C.M., Damiani, D., Dichtchekenian, V., Carneiro, J.D. and D’Amico, E.A. (2002) Hypopituitarism, deficiency of factors V and VIII and von Willebrand factor: An uncommon association. Journal of Pediatric Endocrinology and Metabolism, 15, 331-333. doi:10.1515/JPEM.2002.15.3.331

[182] Grunewald, M., Siegemund, A., Grunewald, A., Konegen, A., Koksch, M. and Griesshammer, M. (2002) Absence of compensatory platelet activation in patients with severe haemophilia, but evidence for a platelet collagen-activation defect. Platelets, 13, 451-458. doi:10.1080/0953710021000059422

[183] Koumbarelis, E., Rosendaal, F.R., Gialeraki, A., Karafoulidou, A., Noteboom, W.M., Loizou, C., Panayotopoulou, C., Markakis, C. and Mandalaki, T. (1994) Epidemiology of haemophilia in Greece: An overview. Thrombosis and Haemostasis, 72, 808-813.

[184] Cheras, P.A., Whitaker, A.N., Blackwell, E.A., Sinton, T.J., Chapman, M.D. and Peacock, K.A. (1997) Hypercoagulability and hypofibrinolysis in primary osteoarthri- 
tis. Clinical Orthopaedics \& Related Research, 334, 5767.

[185] Rosendaal, F.R., Briet, E., Stibbe, J., van Herpen, G., Leuven, J.A., Hofman, A. and Vandenbroucke, J.P. (1990) Haemophilia protects against ischaemic heart disease: A study of risk factors. British Journal of Haematology, 75, 525-530. doi:10.1111/j.1365-2141.1990.tb07793.x

[186] Zhang, Z.G., Chopp, M., Goussev, A., Lu, D., Morris, D., Tsang, W., Powers, C. and Ho, K.L. (1999) Cerebral microvascular obstruction by fibrin is associated with upregulation of PAI-1 acutely after onset of focal embolic ischemia in rats. The Journal of Neuroscience, 19, 1089810907.

[187] Zlokovic, B.V., Wang, L., Sun, N., Haffke, S., Verrall, S., Seeds, N.W., Fisher, M.J. and Schreiber, S.S. (1995) Expression of tissue plasminogen activator in cerebral capillaries: Possible fibrinolytic function of the blood-brain barrier. Neurosurgery, 37, 955-961. doi:10.1227/00006123-199511000-00015

[188] Tamaki, T. and Aoki, N. (1982) Cross-linking of alpha 2-plasmin inhibitor to fibrin catalyzed by activated fibrinstabilizing factor. Journal of Biological Chemistry, 257, 14767-14772.

[189] O’Donnell, J., Mumford, A.D., Manning, R.A. and Laffan, M. (2000) Elevation of FVIII:C in venous thromboembolism is persistent and independent of the acute phase response. Thrombosis and Haemostasis, 83, 10-13.

[190] O’Donnell, J., Mumford, A.D., Manning, R.A. and Laffan, M.A. (2001) Marked elevation of thrombin generation in patients with elevated FVIII: C and venous thromboembolism. British Journal of Haematology, 115, 687-691. doi:10.1046/j.1365-2141.2001.03146.x

[191] Gutstein, W.H. (1988) The central nervous system and atherogenesis: Endothelial injury. Atherosclerosis, 70, 145-154. doi:10.1016/0021-9150(88)90108-6

[192] Lip, G.Y.; Blann, A.D., Farooqi, I.S., Zarifis, J., Sagar, G. and Beevers, D.G. (2002) Sequential alterations in haemorheology, endothelial dysfunction, platelet activation and thrombogenesis in relation to prognosis following acute stroke: The west birmingham stroke project. Blood Coagulation \& Fibrinolysis, 13, 339-347. doi:10.1097/00001721-200206000-00010

[193] Toh, C.H. and Dennis, M. (2003) Current clinical practice. DIC 2002: A review of disseminated intravascular coagulation. Hematology, 8, 65-71. doi:10.1080/1024533031000084213

[194] Tran, T.H., Lammle, B. and Duckert, F. (1984) Factor VIII (procoagulant activity VIII:C, and antigen VIII:CAg, related antigen VIIIR:Ag and ristocetin cofactor VIIIR: Cof) in intensive care patients with clinically suspected disseminated intravascular coagulation (DIC). American Journal of Clinical Pathology, 82, 565-572.

[195] Wu, K.C., Zerhouni, E.A., Judd, R.M., Lugo-Olivieri, C.H., Barouch, L.A., Schulman, S.P., Blumenthal, R.S. and Lima, J.A. (1998) Prognostic significance of microvascular obstruction by magnetic resonance imaging in patients with acute myocardial infarction. Circulation, 97, 765-772. doi:10.1161/01.CIR.97.8.765

[196] Jaeger, B.R. and Labarrere, C.A. (2003) Fibrinogen and atherothrombosis: vulnerable plaque or vulnerable patient? Herz, 28, 530-538. doi:10.1007/s00059-003-2497-5

[197] Zerbino, D.D. and Lukasevich, L.L. (1983) Syndrome of disseminated intravascular coagulation as the principal morphologic manifestation of shock. Arkhiv Patologii, 45, 13-20.

[198] Zerbino, D.D. and Lukasevich, L.L. (1982) Disseminated intravascular coagulation syndrome: morphological criteria. Arkhiv Patologii, 44, 29-35.

[199] Kent, K.M. and Epstein, S.E. (1976) Neural basis for the genesis and control of arrhythmias associated with myocardial infarction. Cardiology, 61, 61-74. doi:10.1159/000169748

[200] Osterud, B. and Bjorklid, E. (2001) The tissue factor pathway in disseminated intravascular coagulation. Semin. Thrombosis and Haemostasis, 27, 605-617. doi:10.1055/s-2001-18866

[201] Taylor, F.B., Jr., Chang, A., Esmon, C.T., D’Angelo, A., Vigano-D’Angelo, S. and Blick, K.E. (1987) Protein C prevents the coagulopathic and lethal effects of $E s$ cherichia coli infusion in the baboon. Journal of Clinical Investigation, 79, 918-925. doi:10.1172/JCI112902

[202] Gerber, B.L., Rochitte, C.E., Melin, J.A., McVeigh, E.R., Bluemke, D.A., Wu, K.C., Becker, L.C. and Lima, J.A. (2000) Microvascular obstruction and left ventricular remodeling early after acute myocardial infarction. Circulation, 101, 2734-2741. doi:10.1161/01.CIR.101.23.2734

[203] Siegbahn, A. (2000) Cellular consequences upon factor VIIa binding to tissue factor. Haemostasis, 30, 41-47.

[204] Hjortoe, G.M., Petersen, L.C., Albrektsen, T., Sorensen, B.B., Norby, P.L., Mandal, S.K., Pendurthi, U.R. and Rao, L.V. (2004) Tissue factor-factor VIIa-specific up-regulation of IL-8 expression in MDA-MB-231 cells is mediated by PAR-2 and results in increased cell migration. Blood, 103, 3029-3037. doi:10.1182/blood-2003-10-3417

[205] Butenas, S., Brummel, K.E., Branda, R.F., Paradis, S.G. and Mann, K.G. (2002) Mechanism of factor VIIa-dependent coagulation in hemophilia blood. Blood, 99, 923-930. doi:10.1182/blood.V99.3.923

[206] Butenas, S., Brummel, K.E., Bouchard, B.A. and Mann, K.G. (2003) How factor VIIa works in hemophilia. Journal of Thrombosis and Haemostasis, 1, 1158-1160. doi:10.1046/j.1538-7836.2003.00181.x

[207] Butenas, S., van’t Veer, C., Cawthern, K., Brummel, K.E. and Mann, K. G. (2000) Models of blood coagulation. Blood Coagul Fibrinolysis, 11, S9-S13. doi:10.1097/00001721-200004001-00003

[208] Himber, J., Wohlgensinger, C., Roux, S., Damico, L.A., Fallon, J.T., Kirchhofer, D., Nemerson, Y. and Riederer, M.A. (2003) Inhibition of tissue factor limits the growth of venous thrombus in the rabbit. Journal of Thrombosis and Haemostasis, 1, 889-895. doi:10.1046/j.1538-7836.2003.00110.x

[209] Cirillo, P., Cali, G., Golino, P., Calabro, P., Forte, L., De Rosa, S., Pacileo, M., Ragni, M., Scopacasa, F., Nitsch, L. and Chiariello, M. (2004) Tissue factor binding of activated factor VII triggers smooth muscle cell proliferation via extracellular signal-regulated kinase activation. Cir- 
culation, 109, 2911-2916. doi:10.1161/01.CIR.0000129312.43547.08

[210] Fleck, R.A., Rao, L.V., Rapaport, S.I. and Varki, N. (1990) Localization of human tissue factor antigen by immunostaining with monospecific, polyclonal anti-human tissue factor antibody. Thrombosis Research, 59, 421-437. doi:10.1016/0049-3848(90)90148-6

[211] McVey, J.H. (1999) Tissue factor pathway. Baillieres Best Practice \& Research Clinical Haematology, 12, 361-372. doi:10.1053/beha.1999.0030

[212] Weiss, H.J., Turitto, V.T., Baumgartner, H.R., Nemerson, Y. and Hoffmann, T. (1989) Evidence for the presence of tissue factor activity on subendothelium. Blood, 73, 968975.

[213] Welty-Wolf, K.E., Carraway, M.S., Miller, D.L., Ortel, T.L., Ezban, M., Ghio, A.J., Idell, S. and Piantadosi, C.A. (2001) Coagulation blockade prevents sepsis-induced respiratory and renal failure in baboons. American Journal of Respiratory and Critical Care Medicine, 164, 19881996.

[214] Mullins, E.S., Kombrinck, K.W., Talmage, K.E., Shaw, M.A., Witte, D.P., Ullman, J.M., Degen, S.J., Sun, W., Flick, M.J. and Degen, J.L. (2009) Genetic elimination of prothrombin in adult mice is not compatible with survival and results in spontaneous hemorrhagic events in both heart and brain. Blood, 113, 696-704. doi:10.1182/blood-2008-07-169003

[215] Audu, P., Nielsen, V.G., Armstead, V., Powell, G., Kim, J., Kim, L. and Mehta, M. (2006) The impact of tissue factor pathway inhibitor on coagulation kinetics determined by thrombelastography. Anesthesia \& Analgesia, 103, 841845. doi:10.1213/01.ane.0000237285.40106.1e

[216] Dalen, P., Blomgren, K. and Bauer, J. (1999) Warfarin can have a negative effect on bone formation. Lakartidningen, 96, 3074.

[217] Vinckier, F. and Vermylen, J. (1984) Wound healing following dental extractions in rabbits: Effects of tranexamic acid, warfarin anti-coagulation, and socket packing. Journal of Dental Research, 63, 646-649. doi:10.1177/00220345840630050701

[218] Stvrtinova, V., Ferencik, M., Hulin, I. and Jahnova, E. (1998) Vascular endothelium as a factor in information transfer between the cardiovascular and immune systems. Bratislavske Lekarske Listy, 99, 5-19.

[219] Siegbahn, A., Johnell, M., Rorsman, C., Ezban, M., Heldin, C.H. and Ronnstrand, L. (2000) Binding of factor VIIa to tissue factor on human fibroblasts leads to activation of phospholipase C and enhanced PDGF-BB-stimulated chemotaxis. Blood, 96, 3452-3458.

[220] Bajaj, M.S., Birktoft, J.J., Steer, S.A. and Bajaj, S.P. (2001) Structure and biology of tissue factor pathway inhibitor. Thrombosis and Haemostasis, 86, 959-972.

[221] Sajadi, S., Ezekowitz, M.D., Dhond, A. and Netrebko, P. (2003) Tissue factor pathway inhibitors as a novel approach to antithrombotic therapy. Drug News Perspect, 16, 363-369. doi:10.1358/dnp.2003.16.6.829308

[222] Burnstock, G. and Ralevic, V. (1994) New insights into the local regulation of blood flow by perivascular nerves and endothelium. British Journal of Plastic Surgery, 47, 527-543. doi:10.1016/0007-1226(94)90136-8

[223] Kvasnicka, T. (2003) NO (nitric oxide) and its significance in regulation of vascular homeostasis. Vnitrni Lekarstvi, 49, 291-296.

[224] Lau, C.S., McLaren, M. and Belch, J.J. (1991) Factor VIII von Willebrand factor antigen levels correlate with symptom severity in patients with Raynaud's phenomenon. Rheumatology, 30, 433-436. doi:10.1093/rheumatology/30.6.433

[225] Muller, A.M., Skrzynski, C., Skipka, G. and Muller, K.M. (2002) Expression of von Willebrand factor by human pulmonary endothelial cells in vivo. Respiration, 69, 526533. doi:10.1159/000066471

[226] Van Zwieten, P.A. and Doods, H.N. (1995) Muscarinic receptors and drugs in cardiovascular medicine. Cardiovascular Drugs and Therapy, 9, 159-167. doi:10.1007/BF00877757

[227] Esmon, C.T. (2004) Crosstalk between inflammation and thrombosis. Maturitas, 47, 305-314. doi:10.1016/j.maturitas.2003.10.015

[228] Zlokovic, B.V. (1997) Antithrombotic, procoagulant, and fibrinolytic mechanisms in cerebral circulation: Implications for brain injury and protection. Neurosurg Focus, 2, e5. doi:10.3171/foc.1997.2.6.8

[229] Groebe, K. (1996) Precapillary servo control of blood pressure and postcapillary adjustment of flow to tissue metabolic status. A new paradigm for local perfusion regulation. Circulation, 94, 1876-1885. doi:10.1161/01.CIR.94.8.1876

[230] Park, G. (2002) Rescue is stressful. Anesthesia \& Analgesia, 95, 263-265.

[231] Schneider, R.A. (1949) The relation of stress to clotting time, relative viscosity and certain other biophysical alterations of the blood in the normotensive and hypertensive subject. Research Publications-Association for Research in Nervous and Mental Disease, 29, 818-831.

[232] Penny, W.F., Weinstein, M., Salzman, E.W. and J.A. (1991) Correlation of circulating von Willebrand factor levels with cardiovascular hemodynamics. Circulation, 83, 1630-1636. doi:10.1161/01.CIR.83.5.1630

[233] Cahalan, M.K., Lurz, F.W., Eger, E.I. 2nd, Schwartz, L.A., Beaupre, P.N. and Smith, J.S. (1987) Narcotics decrease heart rate during inhalational anesthesia. Anesthesia \& Analgesia, 66, 166-170.

[234] Von Kries, R., Jurgens, H., von Voss, H. and Gobel, U. (1981) The clinical relevance of factor VIII: C and factor VII R: Ag determination in newborns. European Journal of Pediatrics, 137, 189-194.

[235] Kocsis, E., Pacher, P., Posa, I., Nieszner, E., Pogatsa, G. and Koltai, M.Z. (2000) Hyperglycaemia alters the endothelium-dependent relaxation of canine coronary arteries. Acta Physiologica Scandinavica, 169, 183-187. doi:10.1046/j.1365-201x.2000.00731.x

[236] Nees, S. (1989) The adenosine hypothesis of metabolic regulation of coronary flow in the light of newly recognized properties of the coronary endothelium. Zeitschrift fur Kardiologie, 78, 42-49. 
[237] Nees, S. (1989) Coronary flow increases induced by adenosine and adenine nucleotides are mediated by the coronary endothelium: A new principle of the regulation of coronary flow. European Heart Journal, 10, 28-35.

[238] Sielenkamper, A.W., Eicker, K. and Van Aken, H. (2000) Thoracic epidural anesthesia increases mucosal perfusion in ileum of rats. Anesthesiology, 93, 844-851. doi:10.1097/00000542-200009000-00036

[239] Akca, O., Melischek, M., Scheck, T., Hellwagner, K., Arkilic, C.F., Kurz, A., Kapral, S., Heinz, T., Lackner, F.X. and Sessler, D.I. (1999) Postoperative pain and subcutaneous oxygen tension. Lancet, 354, 41-42. doi:10.1016/S0140-6736(99)00874-0

[240] Beyak, M.J., Xue, S., Collman, P.I., Valdez, D.T. and Diamant, N.E. (2000) Central nervous system nitric oxide induces oropharyngeal swallowing and esophageal peristalsis in the cat. Gastroenterology, 119, 377-385. doi:10.1053/gast.2000.9308

[241] Beyak, M.J., Collman, P.I., Xue, S., Valdez, D.T. and Diamant, N.E. (2003) Release of nitric oxide in the central nervous system mediates tonic and phasic contraction of the cat lower oesophageal sphincter. Neurogastroenterology \& Motility, 15, 401-407. doi:10.1046/j.1365-2982.2003.00421.x

[242] Chohan, I.S., Singh, I., Vermylen, J. and Verstraete, M. (1977) Effect of furosemide on plasma fibrinolytic activity and urokinase excretion. Experimental Hematology, 5, 153-157.

[243] Kang, J.G., Kim, J.K., Jeong, H.S., Jung, S.C., Ko, M. H., Park, S.H., Cho, J.K., Lee, G.J., Choi, J.W. and Lee, B.D. (2008) A prospective, randomized comparison of the effects of inhaled sevoflurane anesthesia and propofol/ remifentanil intravenous anesthesia on salivary excretion during laryngeal microsurgery. Anesthesia \& Analgesia, 106, 1723-1727. doi:10.1213/ane.0b013e3181730063

[244] Klingel, R., Fassbender, C., Fischer, I., Hattenbach, L., Gumbel, H., Pulido, J. and Koch, F. (2002) Rheopheresis for age-related macular degeneration: A novel indication for therapeutic apheresis in ophthalmology. Therapeutic Apheresis, 6, 271-281. doi:10.1046/j.1526-0968.2002.00418.x

[245] Toda, N., Ayajiki, K. and Okamura, T. (2007) Interaction of endothelial nitric oxide and angiotensin in the circulation. Pharmacological Reviews, 59, 54-87. doi:10.1124/pr.59.1.2

[246] Toda, N., Ayajiki, K. and Okamura, T. (2005) Nitric oxide and penile erectile function. Pharmacology \& Therapeutics, 106, 233-266. doi:10.1016/j.pharmthera.2004.11.011

[247] Fagenholz, P.J., Gutman, J.A., Murray, A.F. and Harris, N.S. (2007) Treatment of high altitude pulmonary edema at $4240 \mathrm{~m}$ in Nepal. High Altitude Medicine \& Biology, 8, 139-146. doi:10.1089/ham.2007.3055

[248] O’Brodovich, H.M., Andrew, M., Gray, G.W. and Coates, G. (1984) Hypoxia alters blood coagulation during acute decompression in humans. Journal of Applied Physiology, 56, 666-670.

[249] Bartsch, P., Haeberli, A., Franciolli, M., Kruithof, E.K. and Straub, P.W. (1989) Coagulation and fibrinolysis in acute mountain sickness and beginning pulmonary edema. Journal of Applied Physiology, 66, 2136-2144.

[250] Kario, K., McEwen, B.S. and Pickering, T.G. (2003) Disasters and the heart: A review of the effects of earthquake-induced stress on cardiovascular disease. Hypertension Research, 26, 355-367.

doi:10.1291/hypres.26.355

[251] Barinov, V.G., Zabelin, I.V. and Solo’vev, V.V. (1989) Analysis of whole blood viscosity in patients with acute myocardial infarction using a rotation viscosimeter. $L a$ boratornoe Delo, 10, 25-27.

[252] Bartsch, P., Waber, U., Haeberli, A., Maggiorini, M., Kriemler, S., Oelz, O. and Straub, W.P. (1987) Enhanced fibrin formation in high-altitude pulmonary edema. Journal of Applied Physiology, 63, 752-757.

[253] Chohan, I.S., Singh, I. and Balakrihsnan, K. (1974) Fibrinolytic activity at high altitude and sodium acetate buffer. Thromb. Thrombosis et Diathesis Haemorrhagica, 32, 65-70.

[254] Ito, H., Taniyama, Y., Iwakura, K., Nishikawa, N., Masuyama, T., Kuzuya, T., Hori, M., Higashino, Y., Fujii, K. and Minamino, T. (1999) Intravenous nicorandil can preserve microvascular integrity and myocardial viability in patients with reperfused anterior wall myocardial infarction. Journal of the American College of Cardiology, 33, 654-660. doi:10.1016/S0735-1097(98)00604-4

[255] Ito, H., Okamura, A., Iwakura, K., Masuyama, T., Hori, M., Takiuchi, S., Negoro, S., Nakatsuchi, Y., Taniyama, Y., Higashino, Y., Fujii, K. and Minamino, T. (1996) Myocardial perfusion patterns related to thrombolysis in myocardial infarction perfusion grades after coronary angioplasty in patients with acute anterior wall myocardial infarction. Circulation, 93, 1993-1999.

doi:10.1161/01.CIR.93.11.1993

[256] Chiariello, M., Brevetti, G., Genovese, A., Cataffo, A., Ambrosio, G. and Condorelli, M. (1983) In Dilazep-induced reduction of ischemic necrosis in rats with coronary artery occlusion, International Journal of Cardiology, 2, 339345. doi:10.1016/0167-5273(83)90004-9

[257] Das, B.B., Wolfe, R.R., Chan, K.C., Larsen, G.L., Reeves, J.T. and Ivy, D. (2004) High-altitude pulmonary edema in children with underlying cardiopulmonary disorders and pulmonary hypertension living at altitude. Archives of Pediatrics \& Adolescent Medicine, 158, 1170-1176. doi:10.1001/archpedi.158.12.1170

[258] Gasser, R., Schafhalter-Zoppoth, I., Schwarz, T., Eber, B., Koppel, H., Lechleitner, P., Puschendorf, B., Dienstl, F. and Klein, W. (1995) Cyclic phenomena in early myocardial infarction. Acta Medica Austriaca, 22, 69-72.

[259] Genovese, A., Chiariello, M., Latte, S., de Alfieri, W., Cacciapuoti, A.A. and Condorelli, M. (1980) Effects of antiplatelet and calcium antagonist drugs on infarct size in rats. Acta Cardiologica, 35, 419-427.

[260] Gibson, C.M., Murphy, S.A., Rizzo, M.J., Ryan, K.A., Marble, S.J., McCabe, C.H., Cannon, C.P., Van de Werf, F. and Braunwald, E. (1999) Relationship between TIMI frame count and clinical outcomes after thrombolytic administration. Thrombolysis in Myocardial Infarction (TIMI) Study Group. Circulation, 99, 1945-1950. 


\section{doi:10.1161/01.CIR.99.15.1945}

[261] Kloner, R.A., Ganote, C.E. and Jennings, R.B. (1974) The "no-reflow" phenomenon after temporary coronary occlusion in the dog. Journal of Clinical Investigation, 54, 1496-1508. doi:10.1172/JCI107898

[262] Mann, K.G., Butenas, S. and Brummel, K. (2003) The dynamics of thrombin formation. Arteriosclerosis, Thrombosis, and Vascular Biology, 23, 17-25. doi:10.1161/01.ATV.0000046238.23903.FC

[263] Roe, M.T., Ohman, E.M., Maas, A.C., Christenson, R.H., Mahaffey, K.W., Granger, C.B., Harrington, R.A., Califf, R.M. and Krucoff, M.W. (2001) Shifting the open-artery hypothesis downstream: The quest for optimal reperfusion. Journal of the American College of Cardiology, 37, 9-18. doi:10.1016/S0735-1097(00)01101-3

[264] Rezkalla, S.H. and Kloner, R.A. (2002) No-reflow phenomenon. Circulation, 105, 656-662. doi:10.1161/hc0502.102867

[265] Segler, C.P. (2001) Prophylaxis of climbers for prevention of embolic accidents. Medical Hypotheses, 57, 472475. doi:10.1054/mehy.2001.1367

[266] Wittstein, I.S., Thiemann, D.R., Lima, J.A., Baughman, K.L., Schulman, S.P., Gerstenblith, G., Wu, K.C., Rade, J.J., Bivalacqua, T.J. and Champion, H.C. (2005) Neurohumoral features of myocardial stunning due to sudden emotional stress. The New England Journal of Medicine, 352, 539-548. doi:10.1056/NEJMoa043046

[267] Lip, G.Y., Blann, A.D., Jones, A.F., Lip, P.L. and Beevers, D.G. (1997) Relation of endothelium, thrombogenesis, and hemorheology in systemic hypertension to ethnicity and left ventricular hypertrophy. American Journal of Cardiology, 80, 1566-1571. doi:10.1016/S0002-9149(97)00749-2

[268] Bogar, L. (2002) Hemorheology and hypertension: Not "chicken or egg" but two chickens from similar eggs. Clinical Hemorheology and Microcirculation, 26, 81-83.

[269] Hlubocka, Z., Umnerova, V., Heller, S., Peleska, J., Jindra, A., Jachymova, M., Kvasnicka, J., Aschermann, M. and Horky, K. (2002) Is mild essential hypertension without obvious organ complications and risk factors associated with increased levels of circulating markers of endothelial dysfunction? Effect of ACE inhibitor therapy. Vnitrni Lekarstvi, 48, 718-723.

[270] Choi, C.Q. (2005) Pressure sensitive. Scientific American, 293, 98. doi:10.1038/scientificamerican0705-26c

[271] Cicco, G., Vicenti, P., Stingi, G.D., Tarallo and Pirrelli, A. (1999) Hemorheology in complicated hypertension. Clinical Hemorheology and Microcirculation, 21, 315- 319.

[272] Danson, E.J. and Paterson, D.J. (2006) Reactive oxygen species and autonomic regulation of cardiac excitability. Journal of Cardiovascular Electrophysiology, 17, S104S112. doi:10.1111/j.1540-8167.2006.00391.x

[273] Esler, M., Rumantir, M., Kaye, D., Jennings, G., Hastings, J., Socratous, F. and Lambert, G. (2001) Sympathetic nerve biology in essential hypertension. Clinical and Experimental Pharmacology and Physiology, 28, 986-989. doi:10.1046/j.1440-1681.2001.03566.x

[274] Farkas, K., Nemcsik, J., Kolossvary, E., Jarai, Z., Nadory,
E., Farsang, C. and Kiss, I. (2005) Impairment of skin microvascular reactivity in hypertension and uraemia. Nephrology Dialysis Transplantation, 20, 1821-1827. doi:10.1093/ndt/gfh944

[275] Friedman, R., Mears, J.G. and Barst, R.J. (1997) Continuous infusion of prostacyclin normalizes plasma markers of endothelial cell injury and platelet aggregation in primary pulmonary hypertension. Circulation, 96, 2782-2784. doi:10.1161/01.CIR.96.9.2782

[276] Naeije, R. and Vachiery, J.L. (2001) Medical therapy of pulmonary hypertension. Conventional therapies. Clinics in Chest Medicine, 22, 517-527. doi:10.1016/S0272-5231(05)70288-4

[277] Savoia, C. and Schiffrin, E.L. (2006) Inflammation in hypertension. Current Opinion in Nephrology \& Hypertension, 15, 152-158.

[278] Veyradier, A., Nishikubo, T., Humbert, M., Wolf, M., Sitbon, O., Simonneau, G., Girma, J.P. and Meyer, D. (2000) Improvement of von Willebrand factor proteolysis after prostacyclin infusion in severe pulmonary arterial hypertension. Circulation, 102, 2460-2462. doi:10.1161/01.CIR.102.20.2460

[279] Vicaut, E. (1999) Microcirculation and arterial hypertension. Drugs, 59, 1-10. doi:10.2165/00003495-199958991-00001

[280] Grant, P.J. (1990) Hormonal regulation of the acute haemostatic response to stress. Blood Coagulation \& Fibrinolysis, 1, 299-306. doi:10.1097/00001721-199008000-00008

[281] Hovinga, J.A., Zeerleder, S., Kessler, P., de Wit, T.R., van Mourik, J.A., Hack, C.E., Ten Cate, H., Reitsma, P.H., Wuillemin, W.A. and Lammle, B. (2007) ADAMTS-13, von Willebrand factor and related parameters in severe sepsis and septic shock. Journal of Thrombosis and Haemostasis, 55, 2284-2290.

[282] Sadler, J.E. (1991) von Willebrand factor. Journal of Biological Chemistry, 266, 22777-22780.

[283] Sadler, J.E., Budde, U., Eikenboom, J.C., Favaloro, E.J., Hill, F.G., Holmberg, L., Ingerslev, J., Lee, C.A., Lillicrap, D., Mannucci, P.M., Mazurier, C., Meyer, D., Nichols, W.L., Nishino, M., Peake, I.R., Rodeghiero, F., Schneppenheim, R., Ruggeri, Z.M., Srivastava, A., Montgomery, R.R. and Federici, A.B. (2006) Update on the pathophysiology and classification of von Willebrand disease: A report of the Subcommittee on von Willebrand Factor. Journal of Thrombosis and Haemostasis, 4, 2103-2114. doi:10.1111/j.1538-7836.2006.02146.X

[284] Van Mourik, J.A., Boertjes, R., Huisveld, I.A., Fijnvandraat, K., Pajkrt, D., van Genderen, P.J. and Fijnheer, R. (1999) von Willebrand factor propeptide in vascular disorders: A tool to distinguish between acute and chronic endothelial cell perturbation. Blood, 94, 179-185.

[285] Mannucci, P.M., Ruggeri, Z.M. and Gagnatelli, G. (1971) Nervous regulation of factor-VIII levels in man. British Journal of Haematology, 20, 195-207. doi:10.1111/j.1365-2141.1971.tb07028.x

[286] Federici, A.B. (2003) The factor VIII/von Willebrand factor complex: Basic and clinical issues. Haematologica, 


\section{8, EREP02.}

[287] Anderson, L.C., Martin, D.J., Phillips, D.L., Killpack, K.J., Bone, S.E. and Rahimian, R. (2006) The influence of gender on parasympathetic vasodilatation in the submandibular gland of the rat. Experimental Physiology, 91, 435-444. doi:10.1113/expphysiol.2005.032730

[288] Hudetz, A.G. (2003) The cerebral microcirculation in ischemia and hypoxemia. The Arisztid G.B. Kovach memorial lecture. Advances in Experimental Medicine and Biology, 530, 347-357.

doi:10.1007/978-1-4615-0075-9_32

[289] Hudetz, A.G. (1997) Regulation of oxygen supply in the cerebral circulation. Advances in Experimental Medicine and Biology, 428, 513-520. doi:10.1007/978-1-4615-5399-1_73

[290] Dijkstra, G., van Goor, H., Jansen, P.L. and Moshage, H. (2004) Targeting nitric oxide in the gastrointestinal tract. Current Opinion in Investigational Drugs, 5, 529-536.

[291] Amano, M., Takahashi, M., Kosaka, T. and Kinoshita, M. (1994) Differential inhibition of platelet aggregation and calcium mobilization by nitroglycerin and stabilized nitric oxide. Journal of Cardiovascular Pharmacology, 24, 860-866. doi:10.1097/00005344-199424060-00002

[292] Baskurt, O.K., Yalcin, O., Ozdem, S., Armstrong, J.K. and Meiselman, H.J. (2004) Modulation of endothelial nitric oxide synthase expression by red blood cell aggregation. American Journal of Physiology Heart and Circulatory Physiology, 286, H222-H229.

doi:10.1152/ajpheart.00532.2003

[293] Brugger, W., Imhof, P., Muller, P., Moser, P. and Reubi, F. (1985) Effect of nitroglycerin on blood rheology in healthy subjects. European Journal of Clinical Pharmacology, 29, 331-336.

[294] Epstein, S.E., Borer, J.S., Kent, K.M., Redwood, D.R., Goldstein, R.E. and Levitt, B. (1976) Protection of ischemic myocardium by nitroglycerin: Experimental and clinical results. Circulation, 53, I191-1198.

[295] Fricchione, G.L., Bilfinger, T.V., Hartman, A., Liu, Y. and Stefano, G.B. (1996) Neuroimmunologic implications in coronary artery disease. Advances in Neuroimmunology, 6, 131-142. doi:10.1016/0960-5428(96)00012-5

[296] Webb, D.J., Muirhead, G.J., Wulff, M., Sutton, J.A., Levi, R. and Dinsmore, W.W. (2000) Sildenafil citrate potentiates the hypotensive effects of nitric oxide donor drugs in male patients with stable angina. Journal of the American College of Cardiology, 36, 25-31. doi:10.1016/S0735-1097(00)00705-1

[297] Griffin, J.H., Fernandez, J.A., Gale, A.J. and Mosnier, L.O. (2007) Activated protein C. Journal of Thrombosis and Haemostasis, 5, 73-80. doi:10.1111/j.1538-7836.2007.02491.x

[298] Hoppensteadt, D.A., Fareed, J., Raake, P. and Raake, W. (2001) Endogenous release of tissue factor pathway inhibitor by topical application of an ointment containing mucopolysaccharide polysulfate to nonhuman primates. Thrombosis Research, 103, 157-163. doi:10.1016/S0049-3848(01)00280-8

[299] Mosnier, L.O., Yang, X.V. and Griffin, J.H. (2007) Acti- vated protein $\mathrm{C}$ mutant with minimal anticoagulant activity, normal cytoprotective activity, and preservation of thrombin activable fibrinolysis inhibitor-dependent cytoprotective functions. The Journal of Biological Chemistry, 282, 33022-33033. doi:10.1074/jbc.M705824200

[300] Robriquet, L., Collet, F., Tournoys, A., Prangere, T., Neviere, R., Fourrier, F. and Guery, B.P. (2006) Intravenous administration of activated protein $\mathrm{C}$ in Pseudomonas-induced lung injury: Impact on lung fluid balance and the inflammatory response. Respiratory Research, 7, 41. doi:10.1186/1465-9921-7-41

[301] Van der Poll, T., Levi, M., Nick, J.A. and Abraham, E. (2005) Activated protein C inhibits local coagulation after intrapulmonary delivery of endotoxin in humans. American Journal of Respiratory and Critical Care Medicine, 171, 1125-1128. doi:10.1164/rccm.200411-1483OC

[302] Ades, P.A., Waldmann, M.L., Meyer, W.L., Brown, K.A., Poehlman, E.T., Pendlebury, W.W., Leslie, K.O., Gray, P.R., Lew, R.R. and LeWinter, M.M. (1996) Skeletal muscle and cardiovascular adaptations to exercise conditioning in older coronary patients. Circulation, 94, 323330. doi:10.1161/01.CIR.94.3.323

[303] Franzoni, F., Plantinga, Y., Femia, F.R., Bartolomucci, F., Gaudio, C., Regoli, F., Carpi, A., Santoro, G. and Galetta, F. (2004) Plasma antioxidant activity and cutaneous microvascular endothelial function in athletes and sedentary controls. Biomedicine \& Pharmacotherapy, 58, 432-436.

[304] Rao, K., Fisher, M.L., Robinson, S., Shorofsky, S. and Gottlieb, S.S. (2007) Effect of chronic changes in heart rate on congestive heart failure. Journal of Cardiac Failure, 13, 269-274. doi:10.1016/j.cardfail.2006.12.001

[305] Eichner, E.R. (1983) Exercise and heart disease. Epidemiology of the "exercise hypothesis". The American Journal of Medicine, 75, 1008-1023. doi:10.1016/0002-9343(83)90882-3

[306] Schmermund, A. (2004) Cardiorespiratory fitness. Importance of exercise for healthiness. Herz, 29, 365-372. doi:10.1007/s00059-004-2584-2

[307] Carr, M.E. (2001) Diabetes mellitus: A hypercoagulable state. Journal of Diabetes and Its Complications, 15, 4454. doi:10.1016/S1056-8727(00)00132-X

[308] Zanesco, A. and Antunes, E. (2007) Effects of exercise training on the cardiovascular system: Pharmacological approaches. Pharmacology \& Therapeutics, 114, 307-317. doi:10.1016/j.pharmthera.2007.03.010

[309] Sandercock, G.R., Bromley, P.D. and Brodie, D.A. (2005) Effects of exercise on heart rate variability: Inferences from meta-analysis. Medicine \& Science in Sports \& Exercise, 37, 433-439. doi:10.1249/01.MSS.0000155388.39002.9D

[310] Van den Burg, P.J., Hospers, J.E., Mosterd, W.L., Bouma, B.N. and Huisveld, I.A. (2000) Aging, physical conditioning, and exercise-induced changes in hemostatic factors and reaction products. Journal of Applied Physiology, 88, 1558-1564.

[311] Prior, B.M., Lloyd, P.G., Yang, H.T. and Terjung, R.L. (2003) Exercise-induced vascular remodeling. Exercise \& Sport Sciences Reviews, 31, 26-33. 
doi:10.1097/00003677-200301000-00006

[312] Lloyd, P.G., Prior, B.M., Li, H., Yang, H.T. and Terjung, R.L. (2005) VEGF receptor antagonism blocks arteriogenesis, but only partially inhibits angiogenesis, in skeletal muscle of exercise-trained rats. American Journal of Physiology Heart and Circulatory Physiology, 288, H759-H768. doi:10.1152/ajpheart.00786.2004

[313] Wijnen, J.A., Kool, M.J., van Baak, M.A., Kuipers, H., de Haan, C.H., Verstappen, F.T., Struijker Boudier, H.A. and Van Bortel, L.M. (1994) Effect of exercise training on ambulatory blood pressure. International Journal of Sports Medicine, 15, 10-15. doi:10.1055/s-2007-1021012

[314] Baron, A.D. (1994) Hemodynamic actions of insulin. American Journal of Physiology, 267, E187-E202.

[315] Lee, Y.H., Wei, F.C., Lee, J. and Su, M.S. (2000) Microcirculatory changes following reperfusion insult in diabetic rat skeletal muscles. Microsurgery, 20, 77-84. doi:10.1002/(SICI)1098-2752(2000)20:2<77::AID-MICR 6>3.0.CO;2-U

[316] Yi, Y., Baoyu, W., Shenyuan, Y., Liangxiang, Z., Hanqing, F. and Yuantao, L. (1999) Changes of nailfold microcirculation in patients of type II diabetes mellitus with diabetic retinopathy. Chinese Medical Sciences Journal, 14, 233-236.

[317] Long, Z.F., Qu, G.Y. and Xu, M. (2001) Relationship between the level of plasma D-dimer and diabetic microangiopathy. Hunan Yi Ke Da Xue Xue Bao, 26, 434436.

[318] Phillip, B., Pastor, D., Bellows, W. and Leung, J.M. (2003) The prevalence of preoperative diastolic filling abnormalities in geriatric surgical patients. Anesthesia \& Analgesia, 97, 1214-1221. doi:10.1213/01.ANE.0000083527.45070.F2

[319] Chen, J. and Goligorsky, M.S. (2006) Premature senescence of endothelial cells: Methusaleh's dilemma. American Journal of Physiology Heart and Circulatory Physiology, 290, H1729-H1739. doi:10.1152/ajpheart.01103.2005

[320] Rakusan, K. and Nagai, J. (1994) Morphometry of arterioles and capillaries in hearts of senescent mice. Cardiovascular Research, 28, 969-972. doi:10.1093/cvr/28.7.969

[321] Boudier, H.A. (1999) Arteriolar and capillary remodelling in hypertension. Drugs, 58, 37-40.

[322] Kawut, S.M., Horn, E.M., Berekashvili, K.K., Garofano, R.P., Goldsmith, R.L., Widlitz, A.C., Rosenzweig, E.B., Kerstein, D. and Barst, R.J. (2005) New predictors of outcome in idiopathic pulmonary arterial hypertension. American Journal of Cardiology, 95, 199-203. doi:10.1016/j.amjcard.2004.09.006

[323] Kawut, S.M., Horn, E.M., Berekashvili, K.K., Widlitz, A.C., Rosenzweig, E.B. and Barst, R.J. (2005) von Willebrand factor independently predicts long-term survival in patients with pulmonary arterial hypertension. Chest, 128, 2355-2362. doi:10.1378/chest.128.4.2355

[324] Lip, G.Y., Edmunds, E., Nuttall, S.L., Landray, M.J., Blann, A.D. and Beevers, D.G. (2002) Oxidative stress in malignant and non-malignant phase hypertension. Jour- nal of Human Hypertension, 16, 333-336. doi:10.1038/sj.jhh.1001386

[325] Lip, G.Y., Edmunds, E., Hee, F.L., Blann, A.D. and Beevers, D.G. (2001) A cross-sectional, diurnal, and follow-up study of platelet activation and endothelial dysfunction in malignant phase hypertension. American Journal of Hypertension, 14, 823-828. doi:10.1016/S0895-7061(01)02045-3

[326] Lip, G.Y., Blann, A.D., Edmunds, E. and Beevers, D.G. (2002) Baseline abnormalities of endothelial function and thrombogenesis in relation to prognosis in essential hypertension. Blood Coagulation \& Fibrinolysis, 13, 35-41. doi:10.1097/00001721-200201000-00005

[327] Ventura, H., Messerli, F.H., Oigman, W. and Suarez, D.H. Dreslinski, G.R., Dunn, F.G., Reisin, E., Frohlich, E.D., (1984) Impaired systemic arterial compliance in borderline hypertension. American Heart Journal, 108, 132-136. doi:10.1016/0002-8703(84)90555-6

[328] Huang, F.Y., Chen, T.L., Fan, S.Z. and Sun, W.Z. (1990) Microvascular perfusion and resistance in extracorporeal cardiopulmonary bypass under hypothermia with highdose narcotic anesthesia-Animal model. Ma Zui Xue Za Zhi, 28, 1-8.

[329] Ito, H. and Iwakura, K. (1998) Assessing the relation between coronary reflow and myocardial reflow. American Journal of Cardiology, 81, 8G-12G. doi:10.1016/S0002-9149(98)00046-0

[330] Trachte, A.L., Lobato, E.B., Urdaneta, F., Hess, P.J., Klodell, C.T., Martin, T.D., Staples, E.D. and Beaver, T.M. (2005) Oral sildenafil reduces pulmonary hypertension after cardiac surgery. The Annals of Thoracic Surgery, 79, 194-197. doi:10.1016/j.athoracsur.2004.06.086

[331] Behr-Roussel, D., Oudot, A., Caisey, S., Coz, O.L., Gorny, D., Bernabe, J., Wayman, C., Alexandre, L. and Giuliano, F.A. (2007) Daily treatment with sildenafil reverses endothelial dysfunction and oxidative stress in an animal model of insulin resistance. European Urology, 53, 12721281.

[332] Ciardella, A.P. (2004) Partial resolution of diabetic macular oedema after systemic treatment with furosemide. British Journal of Ophthalmology, 88, 1224-1225. doi:10.1136/bjo.2004.042580

[333] Korom, S., Hillinger, S., Cardell, M., Zhai, W., Tan, Q., Dutly, A., Leskosek, B. and Weder, W. (2006) Sildenafil extends survival and graft function in a large animal lung transplantation model. European Journal of Cardiothoracic Surgery, 29, 288-293. doi:10.1016/j.ejcts.2005.12.023

[334] Lewis, G.D., Shah, R., Shahzad, K., Camuso, J.M., Pappagianopoulos, P.P., Hung, J., Tawakol, A., Gerszten, R.E., Systrom, D.M., Bloch, K.D. and Semigran, M.J. (2007) Sildenafil improves exercise capacity and quality of life in patients with systolic heart failure and secondary pulmonary hypertension. Circulation, 116, 1555-1562. doi:10.1161/CIRCULATIONAHA.107.716373

[335] Casonato, A., Pontara, E., Bertomoro, A., Cattini, M.G., Soldera, C. and Girolami, A. (2003) Fainting induces an acute increase in the concentration of plasma factor VIII and von Willebrand factor. Haematologica, 88, 688-693. 
[336] Witte, S. (1984) The role of blood coagulation in capillary permeability Vitalmicroscopic contributions. Biorheology, 21, 121-133.

[337] Wojtarowicz, A., Podlasz, P. and Czaja, K. (2003) Adrenergic and cholinergic innervation of pulmonary tissue in the pig. Folia Morphologica, 62, 215-218.

[338] Martin, M.J., Jimenez, M.D. and Motilva, V. (2001) New issues about nitric oxide and its effects on the gastrointestinal tract. Current Pharmaceutical Design, 7, 881-908. doi:10.2174/1381612013397645

[339] Morita-Tsuzuki, Y., Hardebo, J.E. and Bouskela, E. (1993) Inhibition of nitric oxide synthase attenuates the cerebral blood flow response to stimulation of postganglionic parasympathetic nerves in the rat. Journal of Cerebral Blood Flow \& Metabolism, 13, 993-997. doi:10.1038/jcbfm.1993.124

[340] Kvist-Reimer, M., Sundler, F. and Ahren, B. (2002) Effects of chemical sympathectomy by means of 6-hydroxydopamine on insulin secretion and islet morphology in alloxan-diabetic mice. Cell and Tissue Research, 307, 203-209. doi:10.1007/s00441-001-0496-5

[341] Watkins, C.C., Sawa, A., Jaffrey, S., Blackshaw, S., Barrow, R.K., Snyder, S.H. and Ferris, C.D. (2000) Insulin restores neuronal nitric oxide synthase expression and function that is lost in diabetic gastropathy. Journal of Clinical Investigation, 106, 803. doi:10.1172/JCI8273C1

[342] Vincent, M.A., Montagnani, M. and Quon, M.J. (2003) Molecular and physiologic actions of insulin related to production of nitric oxide in vascular endothelium. Current Diabetes Reports, 3, 279-288. doi:10.1007/s11892-003-0018-9

[343] Wamhoff, D., Weiss, D. and Senf, L. (1976) Studies on the influence of glucose infusion on parameters of hemostasis. Zeitschrift fur die Gesamte Innere Medizin und Ihre Grenzgebiete, 31, 711-715.

[344] Ahmed, M.H. (2006) Chloroquine-induced nitric oxide improves insulin sensitivity in rheumatoid arthritis. Medical Hypotheses, 66, 208-209. doi:10.1016/j.mehy.2005.08.039

[345] Ali, S.T. and Rakkah, N.I. (2007) Neurophysiological role of sildenafil citrate (Viagra) on seminal parameters in diabetic males with and without neuropathy. Pakistan Journal of Pharmaceutical Sciences, 20, 36-42.

[346] Ayala, J.E., Bracy, D.P., Julien, B.M., Rottman, J.N., Fueger, P.T. and Wasserman, D.H. (2007) Chronic treatment with sildenafil improves energy balance and insulin action in high fat-fed conscious mice. Diabetes, 56, 10251033. doi:10.2337/db06-0883

[347] Belcaro, G., Marelli, C., Pomante, P., Laurora, G., Cesarone, M.R., Ricci, A., Girardello, R. and Barsotti, A. (1992) Fibrinolytic enhancement in diabetic microangiopathy with defibrotide. Angiology, 43, 793-800. doi:10.1177/000331979204301001

[348] Colantuoni, A., Lapi, D., Paterni, M. and Marchiafava, P.L. (2005) Protective effects of insulin during ischemiareperfusion injury in hamster cheek pouch microcirculation. Journal of Vascular Research, 42, 55-66. doi:10.1159/000083092
[349] Figueras, J., Singh, B.N., Ganz, W. and Swan, H.J. (1979) Haemodynamic and electrocardiographic accompaniments of resting postprandial angina. British Heart Journal, 42, 402-409. doi:10.1136/hrt.42.4.402

[350] Parker, J.D., Bart, B.A., Webb, D.J., Koren, M.J., Siegel, R.L., Wang, H., Malhotra, B., Jen, F. and Glue, P. (2007) Safety of intravenous nitroglycerin after administration of sildenafil citrate to men with coronary artery disease: A double-blind, placebo-controlled, randomized, crossover trial. Critical Care Medicine, 35, 1863-1868. doi:10.1097/01.CCM.0000269371.70738.30

[351] Rich, S., Kaufmann, E. and Levy, P.S. (1992) The effect of high doses of calcium-channel blockers on survival in primary pulmonary hypertension. The New England Journal of Medicine, 327, 76-81. doi:10.1056/NEJM199207093270203

[352] Singh, G., Chaudry, K.I. and Chaudry, I.H. (1993) Diltiazem reduces whole blood viscosity following traumahemorrhagic shock and resuscitation. Circulatory Shock, 39, 231-236.

[353] Brandi, L.S., Frediani, M., Oleggini, M., Mosca, F., Cerri, M., Boni, C., Pecori, N., Buzzigoli, G. and Ferrannini, E. (1990) Insulin resistance after surgery: Normalization by insulin treatment. Clinical Science (Lond), 79, 443-450.

[354] Adamiec, R., Bednarska-Chabowska, D., Adamiec, J. and Wdowczyk, M. (2003) Contribution of selected factors of inflammatory creative process in the vascular endothelial damage in the diabetes patients. Polskie Archiwum Medycyny Wewnętrznej, 110, 683-689.

[355] Caruso, S., Rugolo, S., Mirabella, D., Intelisano, G., Di Mari, L. and Cianci, A. (2006) Changes in clitoral blood flow in premenopausal women affected by type 1 diabetes after single $100-\mathrm{mg}$ administration of sildenafil. Urology, 68, 161-165. doi:10.1016/j.urology.2006.01.059

[356] Caruso, S., Rugolo, S., Agnello, C., Intelisano, G., Di Mari, L. and Cianci, A. (2006) Sildenafil improves sexual functioning in premenopausal women with type 1 diabetes who are affected by sexual arousal disorder: A doubleblind, crossover, placebo-controlled pilot study. Fertility and Sterility, 85, 1496-1501. doi:10.1016/j.fertnstert.2005.10.043

[357] Hassoun, P.M., Thompson, B.T., Steigman, D. and Hales, C.A. (1989) Effect of heparin and warfarin on chronic hypoxic pulmonary hypertension and vascular remodeling in the guinea pig. The American Review of Respiratory Disease, 139, 763-768.

[358] He, G.Z. (1990) Study on the fibrin fibrinogen degradation products levels and its significance in the phlegm of the patients with chronic cor pulmonale through monoclonal antibodies. Chinese Journal of Tuberculosis and Respiratory Diseases, 13, 154-156, 191.

[359] Khan, T.M., Marwat, M.A. and Rehman, H. (2005) Comparison of plasma viscosity and fibrinogen concentration in hypertensive and normotensive diabetics. Journal of Ayub Medical College Abbottabad, 17, 45-47.

[360] McDonagh, P.F. and Hokama, J.Y. (2000) Microvascular perfusion and transport in the diabetic heart. Microcirculation, 7, 163-181. 
[361] Messerli, F.H., Williams, B. and Ritz, E. (2007) Essential hypertension. Lancet, 370, 591-603. doi:10.1016/S0140-6736(07)61299-9

[362] Schafer, A., Fraccarollo, D., Pfortsch, S., Flierl, U., Vogt, C., Pfrang, J., Kobsar, A., Renne, T., Eigenthaler, M., Ertl, G. and Bauersachs, J. (2008) Improvement of vascular function by acute and chronic treatment with the PDE-5 inhibitor sildenafil in experimental diabetes mellitus. British Journal of Pharmacology, 153, 886-893. doi:10.1038/sj.bjp.0707459

[363] Wallis, M.G., Smith, M.E., Kolka, C.M., Zhang, L., Richards, S.M., Rattigan, S. and Clark, M.G. (2005) Acute glucosamine-induced insulin resistance in muscle in vivo is associated with impaired capillary recruitment. Diabetologia, 48, 2131-2139. doi:10.1007/s00125-005-1887-z

[364] Kim, J.A., Tran, N.D., Wang, S.J. and Fisher, M.J. (2003) Astrocyte regulation of human brain capillary endothelial fibrinolysis. Thrombosis Research, 112, 159-165.

[365] Kranenburg, O., Bouma, B., Kroon-Batenburg, L.M., Reijerkerk, A., Wu, Y.P., Voest, E.E. and Gebbink, M.F. (2002) Tissue-type plasminogen activator is a multiligand cross-beta structure receptor. Current Biology, 12, 18331839. doi:10.1016/S0960-9822(02)01224-1

[366] Leibovitz, E., Harpaz, D., Elly, I., Klepfish, A. and Gavish, D. (2004) Persistent anemia in otherwise asymptomatic severe aortic stenosis: A possible indication for valve replacement? The Israel Medical Association Journal, 6, 400-402.

[367] O’Brien, J.R. (1996) Angiodysplasia, haemostasis and capillaries. A hypothesis. Thrombosis Research, 84, 385387.

[368] Basso, I.N. and Keeling, D. (2004) Myocardial infarction following recombinant activated factor VII in a patient with type 2A von Willebrand disease. Blood Coagulation \& Fibrinolysis, 15, 503-504. doi:10.1097/00001721-200408000-00010

[369] Fujita, H., Tomiyama, J., Chuganji, Y., Momoi, M. and Tanaka, T. (2000) Diffuse angiodysplasia of the upper gastrointestinal tract in a patient with hypertrophic obstructive cardiomyopathy. Internal Medicine, 39, 385-388. doi:10.2169/internalmedicine.39.385

[370] Koscielny, J.K., Latza, R., Mursdorf, S., Mrowietz, C., Kiesewetter, H., Wenzel, E. and Jung, F. (2000) Capillary microscopic and rheological dimensions for the diagnosis of von Willebrand disease in comparison to other haemorrhagic diatheses. Journal of Thrombosis and Haemostasis, 84, 981-988.

[371] Rodeghiero, F. (2002) von Willebrand disease: Still an intriguing disorder in the era of molecular medicine. Haemophilia, 8, 292-300. doi:10.1046/j.1365-2516.2002.00611.X

[372] Rosborough, T.K. and Swaim, W.R. (1978) Acquired von Willebrand's disease, platelet-release defect and angiodysplasia. American Journal of Medicine, 65, 96-100. doi:10.1016/0002-9343(78)90698-8

[373] Veyradier, A., Balian, A., Wolf, M., Giraud, V., Montembault, S., Obert, B., Dagher, I., Chaput, J.C., Meyer, D. and Naveau, S. (2001) Abnormal von Willebrand factor in bleeding angiodysplasias of the digestive tract. Gastroenterology, 120, 346-353. doi:10.1053/gast.2001.21204

[374] Warkentin, T.E., Moore, J.C., Anand, S.S., Lonn, E.M. and Morgan, D.G. (2003) Gastrointestinal bleeding, angiodysplasia, cardiovascular disease, and acquired von Willebrand syndrome. Transfusion Medicine Reviews, 17, 272-286. doi:10.1016/S0887-7963(03)00037-3

[375] Ferrell, W.J., Jabs, C.M., Robb, H.J. and Mammen, E.F. (1983) Comparative study of blood clotting factors in anaphylactic and primary and secondary endotoxin shock. Ann. Annals of Clinical \& Laboratory Science, 13, 291298.

[376] Bergamaschini, L., Santangelo, T., Faricciotti, A., Ciavarella, N., Mannucci, P.M. and Agostoni, A. (1996) Study of complement-mediated anaphylaxis in humans. The role of IgG subclasses (IgG1 and/or IgG4) in the complement-activating capacity of immune complexes. The Journal of Immunology, 156, 1256-1261.

[377] Bergamaschini, L., Mannucci, P.M., Federici, A.B., Coppola, R., Guzzoni, S. and Agostoni, A. (1995) Posttransfusion anaphylactic reactions in a patient with severe von Willebrand disease: Role of complement and alloantibodies to von Willebrand factor. Journal of Laboratory and Clinical Medicine, 125, 348-355.

[378] Koch, B., Galioto, F.M. Jr., Kelleher, J. and Goldstein, D. (1984) Physical fitness in children with hemophilia. Archives of Physical Medicine and Rehabilitation, 65, 324326.

[379] Jadhav, M. and Warrier, I. (2000) Anaphylaxis in patients with hemophilia. Seminars in Thrombosis and Hemostasis, 26, 205-208. doi:10.1055/s-2000-9824

[380] Kadar, J.G., Schuster, J. and Hunzelmann, N. (2007) IgEmediated anaphylactic reaction to purified and recombinant factor VIII in a patient with severe haemophilia A. Haemophilia, 13, 104-105. doi:10.1111/j.1365-2516.2006.01339.x

[381] Lindenfeld, J., Weil, J.V., Travis, V.L. and Horwitz, L.D. (2005) Regulation of oxygen delivery during induced polycythemia in exercising dogs. American Journal of Physiology-Heart and Circulatory Physiology, 289, H1821-H1825. doi:10.1152/ajpheart.01016.2004

[382] Suttner, S., Piper, S.N., Kumle, B., Lang, K., Rohm, K.D., Isgro, F. and Boldt, J. (2004) The influence of allogeneic red blood cell transfusion compared with $100 \%$ oxygen ventilation on systemic oxygen transport and skeletal muscle oxygen tension after cardiac surgery. Anesthesia \& Analgesia, 99, 2-11. doi:10.1213/01.ANE.0000120163.44315.47

[383] Lindenfeld, J., Weil, J.V., Travis, V.L. and Horwitz, L.D. (1985) Hemodynamic response to normovolemic polycythemia at rest and during exercise in dogs. Circulation Research, 56, 793-800. doi:10.1161/01.RES.56.6.793

[384] Tous, M., Ferre, N., Vilella, E., Riu, F., Camps, J. and Joven, J. (2004) Circulating blood cells modulate the atherosclerotic process in apolipoprotein E-deficient mice. Metabolism-Clinical and Experimental, 53, 95-100. doi:10.1016/j.metabol.2003.08.012 
[385] Cinar, Y., Demir, G., Pac, M. and Cinar, A.B. (1999) Effect of hematocrit on blood pressure via hyperviscosity. American Journal of Hypertension, 12, 739-743. doi:10.1016/S0895-7061(99)00011-4

[386] Hof, B., van Doorne, C.W., Westerweel, J., Nieuwstadt, F.T., Faisst, H., Eckhardt, B., Wedin, H., Kerswell, R.R. and Waleffe, F. (2004) Experimental observation of nonlinear traveling waves in turbulent pipe flow. Science, 305, 1594-1598. doi:10.1126/science. 1100393

[387] Baskurt, O.K. and Meiselman, H.J. (2008) RBC aggregation: More important than RBC adhesion to endothelial cells as a determinant of in vivo blood flow in health and disease. Microcirculation, 15, 585-590. doi:10.1080/10739680802107447

[388] Baskurt, O.K. and Meiselman, H.J. (2007) Hemodynamic effects of red blood cell aggregation. Indian Journal of Experimental Biology, 45, 25-31.

[389] Baskurt, O.K. and Meiselman, H.J. (2003) Blood rheology and hemodynamics. Seminars in Thrombosis and Hemostasis, 29, 435-450. doi:10.1055/s-2003-44551

[390] Meiselman, H.J., Neu, B., Rampling, M.W. and Baskurt, O.K. (2007) RBC aggregation: Laboratory data and models. Indian Journal of Experimental Biology, 45, 9-17.

[391] Rampling, M.W., Meiselman, H.J., Neu, B. and Baskurt, O.K. (2004) Influence of cell-specific factors on red blood cell aggregation. Biorheology, 41, 91-112.

[392] Seo, T., Fujita, H., Ikeda, Y., Hayashi, T., Kawaguchi, K., Kotake, C., Ueda, S., Kirime, S., Toda, T. and Kobayashi, K. (1991) A case of multiple myeloma with heart failure improved remarkably by chemotherapy alone. Kokyu to Junkan. Respiration \& Circulation, 39, 601-605.

[393] Yalcin, O., Uyuklu, M., Armstrong, J.K., Meiselman, H.J. and Baskurt, O.K. (2004) Graded alterations of RBC aggregation influence in vivo blood flow resistance. American Journal of Physiology-Heart and Circulatory Physiology, 287, H2644-H2650. doi:10.1152/ajpheart.00534.2004

[394] Holt, J.P., Rhode, E.A. and Kines, H. (1968) Ventricular volumes and body weight in mammals. American Journal of Physiology, 215, 704-715.

[395] Parker, K.H. (1977) Instability in arterial blood flow. University Park Press, Baltimore.

[396] Laurent, P., Albaladejo, P., Blacher, J., Rudnichi, A., Smulyan, H. and Safar, M.E. (2003) Heart rate and pulse pressure amplification in hypertensive subjects. American Journal of Hypertension, 16, 363-370. doi:10.1016/S0895-7061(03)00063-3

[397] Bogar, L., Juricskay, I., Kesmarky, G., Kenyeres, P. and Toth, K. (2005) Erythrocyte transport efficacy of human blood: A rheological point of view. European Journal of Clinical Investigation, 35, 687-690. doi:10.1111/j.1365-2362.2005.01562.x

[398] Couch, P. and Stumpf, J.L. (1990) Management of uremic bleeding. Clinical Pharmacology, 9, 673-681.

[399] Casonato, A., Pontara, E., Vertolli, U.P., Steffan, A., Durante, C., De Marco, L., Sartorello, F. and Girolami, A. (2001) Plasma and platelet von Willebrand factor abnormalities in patients with uremia: Lack of correlation with uremic bleeding. Clinical and Applied Thrombosis/Hemostasis, 7, 81-86. doi:10.1177/107602960100700201

[400] Fernandez, F., Goudable, C., Sie, P., Ton-That, H., Durand, D., Suc, J.M. and Boneu, B. (1985) Low haematocrit and prolonged bleeding time in uraemic patients: Effect of red cell transfusions. British Journal of Haematology, 59, 139-148. doi:10.1111/j.1365-2141.1985.tb02974.X

[401] Hardy, J.F., de Moerloose, P. and Samama, C.M. (2006) Massive transfusion and coagulopathy: Pathophysiology and implications for clinical management. Canadian Journal of Anesthesia, 53, S40-S58. doi:10.1007/BF03022251

[402] Kwaan, H.C. and Wang, J. (2003) Hyperviscosity in polycythemia vera and other red cell abnormalities. Seminars in Thrombosis and Hemostasis, 29, 451-458. doi:10.1055/s-2003-44552

[403] Quaknine-Orlando, B., Samama, C.M., Riou, B., Bonnin, P., Guillosson, J.J., Beaumont, J.L. and Coriat, P. (1999) Role of the hematocrit in a rabbit model of arterial thrombosis and bleeding. Anesthesiology, 90, 1454-1461. doi:10.1097/00000542-199905000-00031

[404] Woodyard, C., Davidson, P. and Heath, B. (2006) BP spill highlights aging oil field's increasing problems USA Today.

http://www.usatoday.com/money/industries/energy/2006-08-14-bp-cover-usat_x.htm?POE=click -refer

[405] Glagov, S., Zarins, C., Giddens, D.P. and Ku, D.N. (1988) Hemodynamics and atherosclerosis. Insights and perspectives gained from studies of human arteries. Archives of Pathology \& Laboratory Medicine, 112, 1018-1031.

[406] Glagov, S., Bassiouny, H.S., Giddens, D.P. and Zarins, C.K. (1995) Pathobiology of plaque modeling and complication. Surgical Clinics of North America, 75, 545-556.

[407] Giddens, D.P., Zarins, C.K. and Glagov, S. (1993) The role of fluid mechanics in the localization and detection of atherosclerosis. Journal of Biomechanical Engineering, 115, 588-594. doi:10.1115/1.2895545

[408] Bassiouny, H.S., Zarins, C.K., Kadowaki, M.H. and Glagov, S. (1994) Hemodynamic stress and experimental aortoiliac atherosclerosis. Journal of Vascular Surgery, 19, 426-434. doi:10.1016/S0741-5214(94)70069-9

[409] Davies, P.F. (1995) Flow-mediated endothelial mechanotransduction. Physiological Reviews, 75, 519-560.

[410] Chesebro, J.H., Badimon, J.J., Hassinger, N.L., McBane, R.D. and Fuster, V.V. (1995) Acute Myocardial Infarction and the Role of Aspirin, Heparin, and Warfarin. Journal of Thrombosis and Thrombolysis, 1, 231-235. doi:10.1007/BF01060732

[411] Gordon, J.B., Ganz, P., Nabel, E.G., Fish, R.D., Zebede, J., Mudge, G.H., Alexander, R.W. and Selwyn, A.P. (1989) Atherosclerosis influences the vasomotor response of epicardial coronary arteries to exercise. The Journal of Clinical Investigation, 83, 1946-1952. doi:10.1172/JCI114103

[412] Kaunitz, H. (1977) The significance of dietary fat in arteriosclerosis. An outmoded theory? (Author's transl). 
Munchener Medizinische Wochenschrift, 119, 539-542.

[413] Kensey, K.R. (2003) The mechanistic relationships between hemorheological characteristics and cardiovascular disease. Current Medical Research \& Opinion, 19, 587596. doi:10.1185/030079903125002289

[414] Malek, A.M., Alper, S.L. and Izumo, S. (1999) Hemodynamic shear stress and its role in atherosclerosis. The Journal of the American Medical Association, 282, 20352042. doi:10.1001/jama.282.21.2035

[415] Ross, R. (1999) Atherosclerosis-An inflammatory disease. The New England Journal of Medicine, 340, 115126. doi:10.1056/NEJM199901143400207

[416] Silber, H.A., Bluemke, D.A., Ouyang, P., Du, Y.P., Post, W.S. and Lima, J.A. (2001) The relationship between vascular wall shear stress and flow-mediated dilation: Endothelial function assessed by phase-contrast magnetic resonance angiography. American College of Cardiology, 38, 1859-1865. doi:10.1016/S0735-1097(01)01649-7

[417] Nerem, R.M. and Seed, W.A. (1972) An in vivo study of aortic flow disturbances. Cardiovascular Research, 6, 114. doi:10.1093/cvr/6.1.1

[418] Katritsis, D., Kaiktsis, L., Chaniotis, A., Pantos, J. Efstathopoulos, E. P. and Marmarelis, V. (2007) Wall shear stress: Theoretical considerations and methods of measurement. Progress in Cardiovascular Diseases, 49, 307329. doi:10.1016/j.pcad.2006.11.001

[419] Ku, D.N., Giddens, D.P., Zarins, C.K. and Glagov, S. (1985) Pulsatile flow and atherosclerosis in the human carotid bifurcation. Positive correlation between plaque location and low oscillating shear stress. Arteriosclerosis, 5, 293-302. doi:10.1161/01.ATV.5.3.293

[420] Zhao, S.Z., Xu, X.Y., Hughes, A.D., Thom, S.A. Stanton, A. V., Ariff, B. and Long, Q. (2000) Blood flow and vessel mechanics in a physiologically realistic model of a human carotid arterial bifurcation. Journal of Biomechanics, 33, 975-984. doi:10.1016/S0021-9290(00)00043-9

[421] Zhao, S.Z., Ariff, B., Long, Q., Hughes, A.D., Thom, S.A., Stanton, A.V. and Xu, X.Y. (2002) Inter-individual variations in wall shear stress and mechanical stress distributions at the carotid artery bifurcation of healthy humans. Journal of Biomechanics, 35, 1367-1377. doi:10.1016/S0021-9290(02)00185-9

[422] Biondi, B., Palmieri, E.A., Lombardi, G. and Fazio, S. (2002) Effects of subclinical thyroid dysfunction on the heart. Annals of Internal Medicine, 137, 904-914.

[423] Biondi, B. and Klein, I. (2004) Hypothyroidism as a risk factor for cardiovascular disease. Endocrine, 24, 1-13. doi:10.1385/ENDO:24:1:001

[424] Chambless, L.E., Folsom, A.R., Sharrett, A.R., Sorlie, P., Couper, D., Szklo, M. and Nieto, F.J. (2003) Coronary heart disease risk prediction in the Atherosclerosis Risk in Communities (ARIC) study. Journal of Clinical Epidemiology, 56, 880-890. doi:10.1016/S0895-4356(03)00055-6

[425] Donders, S.H., Lustermans, F.A. and Van Wersch, J.W. (1993) Coagulation factors and lipid composition of the blood in treated and untreated hypertensive patients.
Scand. Journal of Clinical \& Laboratory Investigation, 53, 179-186. doi:10.3109/00365519309088405

[426] Fazio, S., Palmieri, E.A., Lombardi, G. and Biondi, B. (2004) Effects of thyroid hormone on the cardiovascular system. Recent Progress in Hormone Research, 59, 31-50. doi:10.1210/rp.59.1.31

[427] Mehta, J. and Singhal, S. (2003) Hyperviscosity syndrome in plasma cell dyscrasias. Seminars in Thrombosis and Hemostasis, 29, 467-471. doi:10.1055/s-2003-44554

[428] Powell, J., Zadeh, J.A., Carter, G., Greenhalgh, R.M. and Fowler, P.B. (1987) Raised serum thyrotrophin in women with peripheral arterial disease. British Journal of Surgery, 74, 1139-1141. doi:10.1002/bjs.1800741220

[429] Roguski, J., Durkalec, J., Hasik, J., Jaroszewski, F., Krasnik, W., Nowaczyk, J., Rachlewicz, J., Roguska, J. and Ruszkowski, M. (1964) Incidence of clinical criteria of atherosclerosis in hypo- and hyperthyroidism, polycythaemia vera and chronic cor pulmonale (para- and antiatherosclerotic syndromes). Cor et Vasa, 103, 219-230.

[430] Rosenson, R.S., Shott, S. and Katz, R. (2001) Elevated blood viscosity in systemic lupus erythematosus. Seminars in Arthritis and Rheumatism, 31, 52-57. doi:10.1053/sarh.2001.24876

[431] Wolak, T., Todosoui, E., Szendro, G., Bolotin, A. Jonathan, B. S., Flusser, D., Buskila, D., Sukenik, S. and AbuShakra, M. (2004) Duplex study of the carotid and femoral arteries of patients with systemic lupus erythematosus: A controlled study. The Journal of Rheumatology, 31, 909-914.

[432] Alexandrov, A.V., Molina, C.A., Grotta, J.C., Garami, Z., Ford, S.R., Alvarez-Sabin, J., Montaner, J., Saqqur, M., Demchuk, A.M., Moye, L.A., Hill, M.D. and Wojner, A.W. (2004) Ultrasound-enhanced systemic thrombolysis for acute ischemic stroke. The New England Journal of Medicine, 351, 2170-2178. doi:10.1056/NEJMoa041175

[433] Britton, B.J., Hawkey, C., Wood, W.G. and Peele, M. (1974) Stress-A significant factor in venous thrombosis? British Journal of Surgery, 61, 814-820. doi:10.1002/bjs.1800611016

[434] Stuart, J., George, A.J., Davies, A.J., Aukland, A. and Hurlow, R.A. (1981) Haematological stress syndrome in atherosclerosis. Journal of Clinical Pathology, 34, 464-47. doi:10.1136/jcp.34.5.464

[435] Francis, R.B., Jr. (1989) Elevated fibrin D-dimer fragment in sickle cell anemia: Evidence for activation of coagulation during the steady state as well as in painful crisis. Haemostasis, 19, 105-111.

[436] Aluoch, J.R. (1998) Fibrinolytic activity in adult Kenyan patients with sickle cell disease. East African Medical Journal, 75, 351-352.

[437] Devine, D.V., Kinney, T.R., Thomas, P.F., Rosse, W.F. and Greenberg, C.S. (1986) Fragment D-dimer levels: An objective marker of vaso-occlusive crisis and other complications of sickle cell disease. Blood, 68, 317-319.

[438] Famodu, A.A. (1988) Plasma fibrinolytic activity in sickle cell disease. Tropical and Geographical Medicine, 40, 331-333.

[439] Salvaggio, J.E., Arnold, C.A. and Banov, C.H. (1963) 
Long-term anti-coagulation in sickle-cell disease. A clinical study. The New England Journal of Medicine, 269, 182-186. doi:10.1056/NEJM196307252690403

[440] Solomon, L.R. (2008) Treatment and prevention of pain due to vaso-occlusive crises in adults with sickle cell disease: An educational void. Blood, 111, 997-1003. doi:10.1182/blood-2007-07-089144

[441] Chang, S.J., Koh, S.B., Cha, B.S. and Park, J.K. (2002) Job characteristics and blood coagulation factors in Korean male workers. Journal of Occupational and Environmental Medicine, 44, 997-1002. doi:10.1097/00043764-200211000-00004

[442] Kim, K.J., Yang, W.S., Kim, S.B., Lee, S.K. and Park, J.S. (1997) Fibrinogen and fibrinolytic activity in CAPD patients with atherosclerosis and its correlation with serum albumin. Peritoneal Dialysis International, 17, 157-161.

[443] Koenig, W., Rothenbacher, D., Hoffmeister, A., Griesshammer, M. and Brenner, H. (2001) Plasma fibrin D-dimer levels and risk of stable coronary artery disease: Results of a large case-control study. Arteriosclerosis, Thrombosis, and Vascular Biology, 21, 1701-1705. doi:10.1161/hq1001.097020

[444] Koenig, W. (2003) Fibrin(ogen) in cardiovascular disease: An update. Journal of Thrombosis and Haemostasis, 89, 601-609.

[445] Kullo, I.J., Gau, G.T. and Tajik, A.J. (2000) Novel risk factors for atherosclerosis. Mayo Clinic Proceedings, 75, 369-380. doi:10.4065/75.4.369

[446] Mori, Y., Wada, H., Nagano, Y., Deguchi, K., Kita, T. and Shirakawa, S. (1989) Hypercoagulable state in the Watanabe heritable hyperlipidemic rabbit, an animal model for the progression of atherosclerosis. Effect of probucol on coagulation. Journal of Thrombosis and Haemostasis, 61, 140-143.

[447] London, G.M., Marchais, S.J., Guerin, A.P. and Pannier, B. (2004) Arterial stiffness: Pathophysiology and clinical impact. Clinical and Experimental Hypertension, 26, 689-699. doi:10.1081/CEH-200031982

[448] Meiselman, H.J. (1999) Hemorheologic alterations in hypertension: Chicken or egg? Clinical Hemorheology and Microcirculation, 21, 195-200.

[449] Prandoni, P., Bilora, F., Marchiori, A., Bernardi, E., Petrobelli, F., Lensing, A.W., Prins, M.H. and Girolami, A. (2003) An association between atherosclerosis and venous thrombosis. The New England Journal of Medicine, 348, 1435-1441. doi:10.1056/NEJMoa022157

[450] Reich, D.L., Bennett-Guerrero, E., Bodian, C.A., Hossain, S., Winfree, W. and Krol, M. (2002) Intraoperative tachycardia and hypertension are independently associated with adverse outcome in noncardiac surgery of long duration. Anesthesia \& Analgesia, 95, 273-277.

[451] Rudnicka, A.R., Mt-Isa, S. and Meade, T.W. (2006) Associations of plasma fibrinogen and factor VII clotting activity with coronary heart disease and stroke: Prospective cohort study from the screening phase of the Thrombosis Prevention Trial. Journal of Thrombosis and Haemostasis, 4, 2405-2410. doi:10.1111/j.1538-7836.2006.02221.x
[452] Puckett, L.G., Barrett, G., Kouzoudis, D., Grimes, C. and Bachas, L.G. (2003) Monitoring blood coagulation with magnetoelastic sensors. Biosensors and Bioelectronics, 18, 675-681. doi:10.1016/S0956-5663(03)00033-2

[453] Tavel, M.E., Faris, J., Nasser, W.K., Feigebaum, H. and Fisch, C. (1969) Korotkoff sounds. Observations on pressure-pulse changes underlying their formation. Circulation, 39, 465-474. doi:10.1161/01.CIR.39.4.465

[454] Gleick, J. (1988) Chaos: Making a new science.

[455] Biais, M., Nouette-Gaulain, K., Cottenceau, V., Vallet, A., Cochard, J.F., Revel, P. and Sztark, F. (2008) Cardiac output measurement in patients undergoing liver transplantation: Pulmonary artery catheter versus uncalibrated arterial pressure waveform analysis. Anesthesia \& Analgesia, 106, 1480-1486. doi:10.1213/ane.0b013e318168b309

[456] Rim, S.J., Leong-Poi, H., Lindner, J.R., Wei, K., Fisher, N.G. and Kaul, S. (2001) Decrease in coronary blood flow reserve during hyperlipidemia is secondary to an increase in blood viscosity. Circulation, 104, 2704-2709. doi:10.1161/hc4701.099580

[457] Dintenfass, L. (1965) Some observations on the viscosity of pathological human blood plasma. Thrombosis et diathesis haemorrhagica, 13, 492-499.

[458] Bennett, A.F., Gleeson, T.T. and Gorman, G.C. (1981) Anaerobic metabolism in a lizard (Anolis bonairensis) under natural conditions. Physiological and Biochemical Zoology, 54, 237-241.

[459] Dirkmann, D., Hanke, A.A., Gorlinger, K. and Peters, J. (2008) Hypothermia and acidosis synergistically impair coagulation in human whole blood. Anesthesia \& Analgesia, 106, 1627-1632. doi:10.1213/ane.0b013e31817340ad

[460] Hardy, J.F., De Moerloose, P. and Samama, M. (2004) Massive transfusion and coagulopathy: Pathophysiology and implications for clinical management. Canadian Journal of Anesthesia/Journal Canadien D'anesthésie, 51, 293-310. doi:10.1007/BF03018233

[461] Barnhart, M.I. (1978) Platelet responses in health and disease. Molecular and Cellular Biochemistry, 22, 113137. doi:10.1007/BF00496238

[462] Tangelder, G.J., Teirlinck, H.C. and Slaaf, D.W. and Reneman, R.S. (1985) Distribution of blood platelets flowing in arterioles. American Journal of Physiology, 248, H318-H323.

[463] van Gelder, J.M., Nair, C.H. and Dhall, D.P. (1994) The significance of red cell surface area to the permeability of fibrin network. Biorheology, 31, 259-275.

[464] Schramm, W., Schaarschmidt, K., Schmidtler, F. and Schildberg, F.W. (1977) The pathogenesis of postoperative abdominal wound dehiscence. Part II: Hemostasiological checks during the course in selected patient groups (author's transl). MMW (Munchener Medizinische Wochenschrift), 119, 690-694.

[465] Scott, B.H. (1998) Opioids in cardiac surgery: Cardiopulmonary bypass and inflammatory response. International Journal of Cardiology, 64, S35-S41. doi:10.1016/S0167-5273(98)00034-5 
[466] Xia, X., Batra, N., Shi, Q., Bonewald, L.F., Sprague, E. and Jiang, J.X. (2010) Prostaglandin promotion of osteocyte gap junction function through transcriptional regulation of connexin 43 by glycogen synthase kinase 3/betacatenin signaling. Molecular and Cellular Biology, 30, 206-219. doi:10.1128/MCB.01844-08

[467] Nakase, T., Fushiki, S. and Naus, C.C. (2003) Astrocytic gap junctions composed of connexin 43 reduce apoptotic neuronal damage in cerebral ischemia. Stroke, 34, 19871993. doi:10.1161/01.STR.0000079814.72027.34

[468] Kenny, L.C., Baker, P.N., Kendall, D.A., Randall, M.D. and Dunn, W.R. (2002) The role of gap junctions in mediating endothelium-dependent responses to bradykinin in myometrial small arteries isolated from pregnant women. British Journal of Pharmacology, 136, 1085-1088. doi:10.1038/sj.bjp.0704817

[469] Hu, V.W. and Xie, H.Q. (1994) Interleukin-1 alpha suppresses gap junction-mediated intercellular communication in human endothelial cells. Experimental Cell Research, 213, 218-223. doi:10.1006/excr.1994.1193

[470] Henson, J.H., Nazarian, R., Schulberg, K.L., Trabosh, V.A., Kolnik, S.E., Burns, A.R. and McPartland, K.J. (2002) Wound closure in the lamellipodia of single cells: Mediation by actin polymerization in the absence of an actomyosin purse string. Molecular Biology of the Cell, 13, 1001-1014. doi:10.1091/mbc.01-04-0167

[471] Sersa, I., Tratar, G., Mikac, U. and Blinc, A. (2007) A mathematical model for the dissolution of non-occlusive blood clots in fast tangential blood flow. Biorheology, 44, 1-16.

[472] Hahnenkamp, K., Theilmeier, G., Van Aken, H.K. and Hoenemann, C.W. (2002) The effects of local anesthetics on perioperative coagulation, inflammation, and microcirculation. Anesthesia \& Analgesia, 94, 1441-1447.

[473] Melzack, R. and Wall, P.D. (1965) Pain mechanisms: A new theory. Science, 150, 971-979. doi:10.1126/science.150.3699.971

[474] Bromage, P.R. (1996) 50 Years on the wrong side of the reflex arc. Regional Anesthesia and Pain Medicine, 21, 1-4.

[475] Breslow, M.J., Parker, S.D., Frank, S.M., Norris, E.J., Yates, H., Raff, H., Rock, P., Christopherson, R., Rosenfeld, B.A. and Beattie, C. (1993) Determinants of catecholamine and cortisol responses to lower extremity revascularization. The PIRAT Study Group. Anesthesiology, 79, 1202-1209. doi:10.1097/00000542-199312000-00010

[476] Groban, L., Vernon, J.C. and Butterworth, J. (2004) Intrathecal morphine reduces infarct size in a rat model of ischemia-reperfusion injury. Anesthesia \& Analgesia, 98, 903-909. doi:10.1213/01.ANE.0000105878.96434.05

[477] Groeben, H., Schwalen, A., Irsfeld, S., Tarnow, J., Lipfert, P. and Hopf, H.B. (1994) High thoracic epidural anesthesia does not alter airway resistance and attenuates the response to an inhalational provocation test in patients with bronchial hyperreactivity. Anesthesiology, 81, 868-874. doi:10.1097/00000542-199410000-00014

[478] Groudine, S.B., Fisher, H.A., Kaufman, R.P. Jr., Patel, M.
K., Wilkins, L.J., Mehta, S.A. and Lumb, P.D. (1998) Intravenous lidocaine speeds the return of bowel function, decreases postoperative pain, and shortens hospital stay in patients undergoing radical retropubic prostatectomy. Anesthesia \& Analgesia, 86, 235-239.

[479] Kuitunen, A., Hynynen, M., Salmenpera, M., Rasi, V., Jarvinen, A., Scheinin, M., Neuvonen, P.J. and Fyhrquist, F. (1993) Anaesthesia affects plasma concentrations of vasopressin, von Willebrand factor and coagulation factor VIII in cardiac surgical patients. British Journal of Anaesthesia, 70, 173-180. doi:10.1093/bja/70.2.173

[480] Wickipedia. Autonomic dysreflexia \& hyperreflexia. http://www.apparelyzed.com/autonomic.html.

[481] Yeager, M.P., Glass, D.D., Neff, R.K. and Brinck-Johnsen, T. (1987) Epidural anesthesia and analgesia in high-risk surgical patients by preventing nociception that activates the capillary gate component via the spinal pathway. $A n$ esthesiology, 66, 729-736. doi:10.1097/00000542-198706000-00004

[482] Zhang, J., Zhang, W. and Li, B. (2007) The effect of epidural anesthesia with different concentrations of ropivacaine on sevoflurane requirements. Anesthesia \& Analgesia, 104, 984-986. doi:10.1213/01.ane.0000258765.16164.27

[483] Yoo, K., Hwang, J., Jeong, S., Kim, S., Bae, H., Choi, J., Chung, S. and Lee, J. (2006) Anesthetic requirements and stress hormone responses in spinal cord-injured patients undergoing surgery below the level of injury. Anesthesia \& Analgesia, 102, 1223-1228. doi:10.1213/01.ane.0000198429.09694.d3

[484] Christopherson, R., Beattie, C., Frank, S.M., Norris, E.J., Meinert, C.L., Gottlieb, S.O., Yates, H., Rock, P., Parker, S.D. and Perler, B.A. (1993) Perioperative morbidity in patients randomized to epidural or general anesthesia for lower extremity vascular surgery. Perioperative Ischemia Randomized Anesthesia Trial Study Group. Anesthesiology, 79, 422-434. doi:10.1097/00000542-199309000-00004

[485] Christopherson, R., Glavan, N.J., Norris, E.J., Beattie, C., Rock, P., Frank, S.M. and Gottlieb, S.O. (1996) Control of blood pressure and heart rate in patients randomized to epidural or general anesthesia for lower extremity vascular surgery. Perioperative Ischemia Randomized Anesthesia Trial (PIRAT) Study Group. Journal of Clinical Anesthesia, 8, 578-584. doi:10.1016/S0952-8180(96)00139-0

[486] Davis, R.F., DeBoer, L.W. and Maroko, P.R. (1986) Thoracic epidural anesthesia reduces myocardial infarct size after coronary artery occlusion in dogs. Anesthesia \& Analgesia, 65, 711-717. doi:10.1213/00000539-198607000-00001

[487] Exadaktylos, A.K., Buggy, D.J., Moriarty, D.C., Mascha, E. and Sessler, D.I. (2006) Can anesthetic technique for primary breast cancer surgery affect recurrence or metastasis? Anesthesiology, 105, 660-664. doi:10.1097/00000542-200610000-00008

[488] Filimonovic, J., Gvozdic, B., Krivic, B., Acimovic, M., Tulic, C. and Hadzi-Djokic, J. (2005) Anesthesia for radical prostatectomy. Acta Chirurgica Iugoslavica, 52, 113117. doi:10.2298/ACI0504113F 
[489] Giesecke, K., Hamberger, B., Jarnberg, P.O., Klingstedt, C. and Persson, B. (1988) High- and low-dose fentanyl anaesthesia: Hormonal and metabolic responses during cholecystectomy. British Journal of Anaesthesia, 61, 575582. doi:10.1093/bja/61.5.575

[490] Modig, J., Borg, T., Karlstrom, G., Maripuu, E. and Sahlstedt, B. (1983) Thromboembolism after total hip replacement: Role of epidural and general anesthesia. $A n-$ esthesia \& Analgesia, 62, 174-180.

[491] Modig, J., Borg, T., Bagge, L. and Saldeen, T. (1983) Role of extradural and of general anaesthesia in fibrinolysis and coagulation after total hip replacement. British Journal of Anaesthesia, 55, 625-629. doi:10.1093/bja/55.7.625

[492] Modig, J. (1985) The role of lumbar epidural anaesthesia as antithrombotic prophylaxis in total hip replacement. Acta chirurgica Scandinavica, 151, 589-594.

[493] Moore, C.M., Cross, M.H., Desborough, J.P., Burrin, J. M., Macdonald, I.A. and Hall, G.M. (1995) Hormonal effects of thoracic extradural analgesia for cardiac surgery. British Journal of Anaesthesia, 75, 387-393.

[494] Pflug, A.E. and Halter, J.B. (1981) Effect of spinal anesthesia on adrenergic tone and the neuroendocrine responses to surgical stress in humans. Anesthesiology, 55, 120-126. doi:10.1097/00000542-198108000-00007

[495] Rodgers, A., Walker, N., Schug, S., McKee, A., Kehlet, H., van Zundert, A., Sage, D., Futter, M., Saville, G., Clark, T. and MacMahon, S. (2000) Reduction of postoperative mortality and morbidity with epidural or spinal anaesthesia: Results from overview of randomised trials. British Medical Journal, 321, 1493. doi:10.1136/bmj.321.7275.1493

[496] Roizen, M.F. (1988) Should we all have a sympathectomy at birth? Or at least preoperatively? Anesthesiology, 68, 482-484. doi:10.1097/00000542-198804000-00002

[497] Rosenfeld, B.A., Beattie, C., Christopherson, R., Norris, E.J., Frank, S.M., Breslow, M.J., Rock, P., Parker, S.D., Gottlieb, S.O. and Perler, B.A. (1993) The effects of different anesthetic regimens on fibrinolysis and the development of postoperative arterial thrombosis. Perioperative Ischemia Randomized Anesthesia Trial Study Group. Anesthesiology, 79, 435-443.

doi:10.1097/00000542-199309000-00005

[498] Sebel, P.S. and Bovil, J.G. (1982) Cardiovascular effects of sufentanil anesthesia. Anesthesia \& Analgesia, 61, 115-119. doi:10.1213/00000539-198202000-00009

[499] Treschan, T.A., Taguchi, A., Ali, S.Z., Sharma, N., Kabon, B., Sessler, D.I. and Kurz, A. (2003) The effects of epidural and general anesthesia on tissue oxygenation. Anesthesia \& Analgesia, 96, 1553-1557. doi:10.1213/01.ANE.0000063824.43113.DB

[500] Tverskoy, M., Gelman, S., Fowler, K.C. and Bradley, E.L. (1985) Influence of fentanyl and morphine on intestinal circulation. Anesthesia \& Analgesia, 64, 577-584. doi:10.1213/00000539-198506000-00004

[501] Tverskoy, M., Cozacov, C., Ayache, M., Bradley, E.L., Jr. and Kissin, I. (1990) Postoperative pain after inguinal herniorrhaphy with different types of anesthesia. Anes- thesia \& Analgesia, 70, 29-35. doi:10.1213/00000539-199001000-00006

[502] Woolf, C.J. and Chong, M.S. (1993) Preemptive analgesia-Treating postoperative pain by preventing the establishment of central sensitization. Anesthesia \& Analgesia, 77, 362-379.

[503] Woolf, C.J. (1983) Evidence for a central component of post-injury pain hypersensitivity. Nature, 306, 686-688. doi:10.1038/306686a0

[504] Woolf, C.J. and Wall, P.D. (1986) Morphine-sensitive and morphine-insensitive actions of C-fibre input on the rat spinal cord. Neuroscience Letters, 64, 221-225. doi:10.1016/0304-3940(86)90104-7

[505] Anand, K.J., Sippell, W.G. and Aynsley-Green, A., (1987) Randomised trial of fentanyl anaesthesia in preterm babies undergoing surgery: Effects on the stress response. Lancet, 1, 62-66. doi:10.1016/S0140-6736(87)91907-6

[506] Anand, K.J. and Hickey, P.R. (1992) Halothane-morphine compared with high-dose sufentanil for anesthesia and postoperative analgesia in neonatal cardiac surgery. The New England Journal of Medicine, 326, 1-9. doi:10.1056/NEJM199201023260101

[507] Anand, K.J., Hansen, D.D. and Hickey, P.R. (1990) Hormonal-metabolic stress responses in neonates undergoing cardiac surgery. Anesthesiology, 73, 661-670. doi:10.1097/00000542-199010000-00012

[508] Edde, R.R. (1981) Hemodynamic changes prior to and after sternotomy in patients anesthetized with high-dose fentanyl. Anesthesiology, 55, 444-446. doi:10.1097/00000542-198110000-00018

[509] Fisk, N.M., Gitau, R., Teixeira, J.M., Giannakoulopoulos, X., Cameron, A.D. and Glover, V.A. (2001) Effect of direct fetal opioid analgesia on fetal hormonal and hemodynamic stress response to intrauterine needling. Anesthesiology, 95, 828-835. doi:10.1097/00000542-200110000-00008

[510] Hickey, P.R. and Hansen, D.D. (1991) High-dose fentanyl reduces intraoperative ventricular fibrillation in neonates with hypoplastic left heart syndrome. Journal of Clinical Anesthesia, 3, 295-300. doi:10.1016/0952-8180(91)90223-A

[511] Khomulo, P.S., Dmitrieva, N.A. and Eliner, G.I. (1976) Atherosclerosis in rabbits induced by prolonged electrical stimulation of the hypothalamus. Byulleten' Eksperimental' noi Biologii i Meditsiny, 82, 1294-1296.

[512] Khomulo, P.S., Ambrozas, I.V., Dmitrieva, N.A., Zharova, I.P. and Nikolaev, V.I. (1980) Development of atherosclerosis in alternating prolonged electrostimulation of the negative and positive hypothalamic emotiogenic zones. Kardiologiia, 20, 104-108.

[513] Gutstein, W.H. and Parl, F. (1978) Neural factors in experimental degenerative arteriopathy. Lipids, 13, 380-382. doi:10.1007/BF02533736

[514] Gutstein, W.H., Harrison, J., Parl, F., Ku, G. and Avtable, M. (1978) Neural factors contribute to atherogenesis. Science, 199, 449-451. doi:10.1126/science.619468

[515] Parker, E.S., Cahill, L. and McGaugh, J.L. (2006) A case of unusual autobiographical remembering. Neurocase, 12, 
35-49. doi:10.1080/13554790500473680

[516] Price, J. (2008) The woman who can't forget: The extraordinary story of living with the most remarkable memory known to science-A memoir. Free Press, a Division of Simon and Schuster, 263.

[517] Wickipedia. Hyperthymestic syndrome. http://en.wikipedia.org/wiki/Hyperthymesia

[518] Hobson, J.A. (1997) Dreaming as delirium: A mental status analysis of our nightly madness. Seminars in Neurology, 17, 121-128. doi:10.1055/s-2008-1040921

[519] Chapman, C.R., Tuckett, R.P. and Song, C.W. (2008) Pain and stress in a systems perspective: Reciprocal neural, endocrine, and immune interactions. Journal of Pain, 9, 122-145. doi:10.1016/j.jpain.2007.09.006

[520] Jern, C., Eriksson, E., Tengborn, L., Risberg, B., Wadenvik, H. and Jern, S. (1989) Changes of plasma coagulation and fibrinolysis in response to mental stress. Journal of Thrombosis and Haemostasis, 62, 767-771.

[521] Feigl, E.O., Buffington, C.W. and Nathan, H.J. (1987) Adrenergic coronary vasoconstriction during myocardial underperfusion. Circulation, 75, I1-I5.

[522] Freeman, L.J., Nixon, P.G., Sallabank, P. and Reaveley, D. (1987) Psychological stress and silent myocardial ischemia. American Heart Journal, 114, 477-482. doi:10.1016/0002-8703(87)90741-1

[523] Sano, H. and Itoh, H. (1998) Idiopathic insomnia. Nippon Rinsho, 56, 361-364.

[524] Wong, K.C. (1983) Narcotics are not expected to produce unconsciousness and amnesia. Anesthesia \& Analgesia, 62, 625-626. doi:10.1213/00000539-198307000-00001

[525] Bovill, J.G., Sebel, P.S. and Stanley, T.H. (1984) Opioid analgesics in anesthesia: With special reference to their use in cardiovascular anesthesia. Anesthesiology, 61, 731755. doi:10.1097/00000542-198412000-00018

[526] Bovill, J.G., Sebel, P.S., Fiolet, J.W., Touber, J.L., Kok, K. and Philbin, D.M. (1983) The influence of sufentanil on endocrine and metabolic responses to cardiac surgery. Anesthesia \& Analgesia, 62, 391-397. doi:10.1213/00000539-198304000-00003

[527] Behar, M. (2007) Can Fear Be Forgotten Popular Science. http://www.popsci.com/scitech/article/2007-12/can-fear-b e-forgotten

[528] Dorges, V., Wenzel, V., Dix, S., Kuhl, A., Schumann, T., Huppe, M., Iven, H. and Gerlach, K. (2002) The effect of midazolam on stress levels during simulated emergency medical service transport: A placebo-controlled, doseresponse study. Anesthesia \& Analgesia, 95, 417-422. doi:10.1213/00000539-200208000-00034

[529] Mukamal, K.J., Cushman, M., Mittleman, M.A., Tracy, R.P. and Siscovick, D.S. (2004) Alcohol consumption and inflammatory markers in older adults: The cardiovascular health study. Atherosclerosis, 173, 79-87. doi:10.1016/j.atherosclerosis.2003.10.011

[530] Hoffmeister, A., Imhof, A., Rothenbacher, D., Khuseyinova, N., Brenner, H. and Koenig, W. (2003) Moderate alcohol consumption and plasma concentration of sensitive markers of inflammation. Comment on an atheropro- tective relationship. Deutsche Medizinische Wochenschrift, 128, 2237-2241. doi:10.1055/s-2003-43101

[531] Wannamethee, S.G., Lowe, G.D., Shaper, G., Whincup, P.H., Rumley, A., Walker, M. and Lennon, L. (2003) The effects of different alcoholic drinks on lipids, insulin and haemostatic and inflammatory markers in older men. Journal of Thrombosis and Haemostasis, 90, 1080-1087.

[532] Mangano, D.T., Siliciano, D., Hollenberg, M., Leung, J. M., Browner, W.S., Goehner, P., Merrick, S. and Verrier, E. (1992) Postoperative myocardial ischemia. Therapeutic trials using intensive analgesia following surgery. The Study of Perioperative Ischemia (SPI) Research Group. Anesthesiology, 76, 342-353. doi:10.1097/00000542-199203000-00004

[533] Myles, P.S., Hunt, J.O., Fletcher, H., Watts, J., Bain, D., Silvers, A. and Buckland, M.R. (2002) Remifentanil, fentanyl, and cardiac surgery: A double-blinded, randomized, controlled trial of costs and outcomes. Anesthesia \& Analgesia, 95, 805-812.

[534] Kario, K., Matsuo, T., Kobayashi, H., Yamamoto, K. and Shimada, K. (1997) Earthquake-induced potentiation of acute risk factors in hypertensive elderly patients: Possible triggering of cardiovascular events after a major earthquake. Journal of the American College of Cardiology, 29, 926-933. doi:10.1016/S0735-1097(97)00002-8

[535] Kario, K., Matsuo, T., Kobayashi, H., Matsuo, M., Sakata, T., Miyata, T. and Shimada, K. (1996) Factor VII hyperactivity and endothelial cell damage are found in elderly hypertensives only when concomitant with microalbuminuria. Arteriosclerosis, Thrombosis, and Vascular Biology, 16, 455-461. doi:10.1161/01.ATV.16.3.455

[536] Kario, K., Matsuo, T., Kayaba, K., Soukejima, S., Kagamimori, S. and Shimada, K. (1998) Earthquakeinduced cardiovascular disease and related risk factors in focusing on the Great Hanshin-Awaji Earthquake. Journal of Epidemiology, 8, 131-139. doi:10.2188/jea.8.131

[537] Kario, K. and Matsuo, T. (1995) Increased incidence of cardiovascular attacks in the epicenter just after the Hanshin-Awaji earthquake. Journal of Thrombosis and Haemostasis, 74, 1207.

[538] Matsuo, T., Suzuki, S., Kodama, K. and Kario, K. (1998) Hemostatic activation and cardiac events after the 1995 Hanshin-Awaji earthquake. International Journal of Hematology, 67, 123-129. doi:10.1016/S0925-5710(97)00118-7

[539] Matsuo, T., Suzuki, S., Kario, K. and Kobayashi, H. (1997) Acute myocardial infarction in the 1995 HanshinAwaji Earthquake. Rinsho Byori, 133-141.

[540] Matsuo, T., Kobayashi, H., Kario, K., Suzuki, S. and Matsuo, M. (1998) Role of biochemical and fibrinolytic parameters on cardiac events associated with HanshinAwaji earthquake-induced stress. Rinsho Byori, 46, 593598.

[541] Pignalberi, C., Ricci, R. and Santini, M. (2002) Psychological stress and sudden death. Italian Heart Journal, 3, 1011-1021.

[542] Von Kanel, R., Hepp, U., Buddeberg, C., Keel, M., Mica, 
L., Aschbacher, K. and Schnyder, U. (2006) Altered blood coagulation in patients with posttraumatic stress disorder. Psychosomatic Medicine, 68, 598-604. doi:10.1097/01.psy.0000221229.43272.9d

[543] Hao, Z., Jiang, X., Sharafeih, R., Shen, S., Hand, A.R., Cone, R.E. and O'Rourke, J. (2005) Stimulated release of tissue plasminogen activator from artery wall sympathetic nerves: Implications for stress-associated wall damage. Stress, 8, 141-149. doi:10.1080/10253890500168098

[544] Ranjbar, F., Akbarzadeh, F., Kazemi, K. and Safaeiyan, A. (2007) Relaxation therapy in the background of standard antihypertensive drug treatment is effective in management of moderate to severe essential hypertension. Saudi Medical Journal, 28, 1353-1356.

[545] Landesberg, G., Mosseri, M., Zahger, D., Wolf, Y., Perouansky, M., Anner, H., Drenger, B., Hasin, Y., Berlatzky, Y. and Weissman, C. (2001) Myocardial infarction after vascular surgery: The role of prolonged stress-induced, ST depression-type ischemia. Journal of the American College of Cardiology, 37, 1839-1845. doi:10.1016/S0735-1097(01)01265-7

[546] Mangano, D.T., Hollenberg, M., Fegert, G., Meyer, M.L., London, M.J., Tubau, J.F. and Krupski, W.C. (1991) Perioperative myocardial ischemia in patients undergoing noncardiac surgery-I: Incidence and severity during the 4 day perioperative period. The Study of Perioperative Ischemia (SPI) Research Group. Journal of the American College of Cardiology, 17, 843-850. doi:10.1016/0735-1097(91)90863-5

[547] Fornek, J.L., Korth, M.J. and Katze, M.G. (2007) Use of functional genomics to understand influenza-host interactions. Advances in Virus Research, 70, 81-100. doi:10.1016/S0065-3527(07)70003-9

[548] Kipnis, E., Guery, B.P., Tournoys, A., Leroy, X., Robriquet, L., Fialdes, P., Neviere, R. and Fourrier, F. (2004) Massive alveolar thrombin activation in Pseudomonas aeruginosa-induced acute lung injury. Shock, 21, 444-451. doi:10.1097/00024382-200405000-00008

[549] Bonacci, J.V., Harris, T., Wilson, J.W. and Stewart, A.G. (2003) Collagen-induced resistance to glucocorticoid anti-mitogenic actions: A potential explanation of smooth muscle hyperplasia in the asthmatic remodelled airway. British Journal of Pharmacology, 138, 1203-1206. doi:10.1038/sj.bjp.0705135

[550] Hesselvik, J.F., Blomback, M., Brodin, B. and Maller, R. (1989) Coagulation, fibrinolysis, and kallikrein systems in sepsis: Relation to outcome. Critical Care Medicine, 17, 724-733. doi:10.1097/00003246-198908000-00002

[551] Healy, D.P. (2002) New and emerging therapies for sepsis. The Annals of Pharmacotherapy, 36, 648-654. doi:10.1345/aph.1A283

[552] Warr, T.A., Rao, L.V. and Rapaport, S.I. (1990) Disseminated intravascular coagulation in rabbits induced by administration of endotoxin or tissue factor: Effect of anti-tissue factor antibodies and measurement of plasma extrinsic pathway inhibitor activity. Blood, 75, 14811489.

[553] Angelov, A. (1989) Intravascular coagulation in amniotic fluid embolism. Akusherstvo $i$ Ginekologiia, 28, 24-29.

[554] Lau, G. and Chui, P.P. (1994) Amniotic fluid embolism: A review of 10 fatal cases. Singapore Medical Journal, 35, 180-183.

[555] Lockwood, C.J., Bach, R., Guha, A., Zhou, X.D., Miller, W.A. and Nemerson, Y. (1991) Amniotic fluid contains tissue factor, a potent initiator of coagulation. American Journal of Obstetrics \& Gynecology, 165, 1335-1341.

[556] Modesti, P.A., Gamberi, T., Bazzini, C., Borro, M., Romano, S.M., Cambi, G.E., Corvi, A., Dorigo, W., Paparella, L., Pratesi, C., Carini, M., Gensini, G. and Modesti, A. (2009) Response of serum proteome in patients undergoing infrarenal aortic aneurysm repair. Anesthesiology, 111, 844-854. doi:10.1097/ALN.0b013e3181b1607f

[557] Adembri, C., Kastamoniti, E., Bertolozzi, I., Vanni, S., Dorigo, W., Coppo, M., Pratesi, C., De Gaudio, A.R., Gensini, G.F. and Modesti, P.A. (2004) Pulmonary injury follows systemic inflammatory reaction in infrarenal aortic surgery. Critical Care Medicine, 32, 1170-1177. doi:10.1097/01.CCM.0000124875.98492.11

[558] Garvin, S., Muehlschlegel, J.D., Perry, T.E., Chen, J., Liu, K.Y., Fox, A.A., Collard, C.D., Aranki, S.F., Shernan, S. K. and Body, S.C. (2009) Postoperative activity, but not preoperative activity, of antithrombin is associated with major adverse cardiac events after coronary artery bypass graft surgery. Anesthesia \& Analgesia, 111, 862-869. doi:10.1213/ANE.0b013e3181b7908c

[559] Herrero, J.F., Laird, J.M. and Lopez-Garcia, J.A. (2000) Wind-up of spinal cord neurones and pain sensation: Much ado about something? Progress in Neurobiology, 61, 169-203. doi:10.1016/S0301-0082(99)00051-9

[560] Coderre, T.J. and Melzack, R. (1987) Cutaneous hyperalgesia: Contributions of the peripheral and central nervous systems to the increase in pain sensitivity after injury. Brain Research, 404, 95-106. doi:10.1016/0006-8993(87)91359-X

[561] Cousins, M.J. and John, J. (1989) Bonica distinguished lecture. Acute pain and the injury response: Immediate and prolonged effects. Regional Anesthesia and Pain Medicine, 14, 162-179.

[562] Ofek, H. and Defrin, R. (2007) The characteristics of chronic central pain after traumatic brain injury. Pain, 131, 330-340. doi:10.1016/j.pain.2007.06.015

[563] Wall, P.D. and Woolf, C.J. (1986) The brief and the prolonged facilitatory effects of unmyelinated afferent input on the rat spinal cord are independently influenced by peripheral nerve section. Neuroscience, 17, 1199-1205. doi:10.1016/0306-4522(86)90087-4

[564] Baum, M., Demicheli, R., Hrushesky, W. and Retsky, M. (2005) Does surgery unfavourably perturb the "natural history" of early breast cancer by accelerating the appearance of distant metastases? European Journal of Cancer, 41, 508-515. doi:10.1016/j.ejca.2004.09.031

[565] Berglund, U., Wallentin, L. and von Schenck, H. (1988) Platelet function and plasma fibrinogen and their relations to gender, smoking habits, obesity and beta-blocker treatment in young survivors of myocardial infarction. 
Journal of Thrombosis and Haemostasis, 60, 21-24.

[566] Inoue, K., Takano, H., Yanagisawa, R., Sakurai, M. and Yoshikawa, T. (2004) Surgical stress in ARDS open-lung biopsy. Chest, 126, 1383-1384, author reply 1384. doi:10.1378/chest.126.4.1383

[567] Abraham, E. (1991) Physiologic stress and cellular ischemia: Relationship to immunosuppression and susceptibility to sepsis. Critical Care Medicine, 19, 613-618. doi:10.1097/00003246-199105000-00007

[568] Avikainen, V. (1977) Coagulation disorders in severely and critically injured patients. Annales Chirurgiae et Gynaecologiae, 66, 269-277.

[569] Sielenkamper, A.W., Meyer, J., Kloppenburg, H., Eicker, K. and Van Aken, H. (2001) The effects of sepsis on gut mucosal blood flow in rats. European Journal of Anaesthesiology, 18, 673-678.

[570] Garrison, R.N., Spain, D.A., Wilson, M.A., Keelen, P.A. and Harris, P.D. (1998) Microvascular changes explain the "two-hit" theory of multiple organ failure. Annals of Surgery, 227, 851-860. doi:10.1097/00000658-199806000-00008

[571] Weijer, S., Schoenmakers, S.H., Florquin, S., Levi, M., Vlasuk, G.P., Rote, W.E., Reitsma, P.H., Spek, C.A. and van der Poll, T. (2004) Inhibition of the tissue factor/factor VIIa pathway does not influence the inflammatory or antibacterial response to abdominal sepsis induced by Escherichia coli in mice. Journal of Infectious Diseases, 189, 2308-2317. doi:10.1086/421031

[572] Wei, S.J. (1990) The assessment of factor VIII-related antigen in endothelial cells of pulmonary blood vessels in multiple organ failure. Zhonghua Jie He He Hu Xi Za Zhi, 13, 346-348, 380.

[573] Moalli, R., Doyle, J.M., Tahhan, H.R., Hasan, F.M., Braman, S.S. and Saldeen, T. (1989) Fibrinolysis in critically ill patients. American Review of Respiratory Disease, 140, 287-293. doi:10.1164/ajrccm/140.2.287

[574] Modig, J., Borg, T., Wegenius, G., Bagge, L. and Saldeen, T. (1983) The value of variables of disseminated intravascular coagulation in the diagnosis of adult respiratory distress syndrome. Acta Anaesthesiologica Scandinavica, 27, 369-375. doi:10.1111/j.1399-6576.1983.tb01970.x

[575] Rubin, D.B., Wiener-Kronish, J.P., Murray, J.F., Green, D.R., Turner, J., Luce, J.M., Montgomery, A.B., Marks, J. D. and Matthay, M.A. (1990) Elevated von Willebrand factor antigen is an early plasma predictor of acute lung injury in nonpulmonary sepsis syndrome. Journal of Clinical Investigation, 86, 474-480. doi:10.1172/JCI114733

[576] Draheim, C.C., McCubbin, J.A. and Williams, D.P. (2002) Differences in cardiovascular disease risk between nondiabetic adults with mental retardation with and without Down syndrome. American Journal on Mental Retardation, 107, 201-211. doi:10.1352/0895-8017(2002)107<0201:DICDRB>2.0.C $\underline{\mathrm{O} ; 2}$

[577] Draheim, C.C., Geijer, J.R. and Dengel, D.R. (2010) Comparison of intima-media thickness of the carotid ar- tery and cardiovascular disease risk factors in adults with versus without the Down syndrome. American Journal of Cardiology, 106, 1512-1516. doi:10.1016/j.amjcard.2010.06.079

[578] Bilora, F., Boccioletti, V., Zanon, E., Petrobelli, F., Girolami, A. and Hemophilia, A. (2001) von Willebrand disease, and atherosclerosis of abdominal aorta and leg arteries: Factor VIII and von Willebrand factor defects appear to protect abdominal aorta and leg arteries from atherosclerosis. Clinical and Applied Thrombosis/Hemostasis, 7, 311-313. doi:10.1177/107602960100700411

[579] Wang, X., Wang, E., Kavanagh, J.J. and Freedman, R.S. (2005) Ovarian cancer, the coagulation pathway, and inflammation. Journal of Translational Medicine, 3, 25. doi:10.1186/1479-5876-3-25

[580] von Tempelhoff, G.F., Schonmann, N. and Heilmann, L. (2002) Thrombosis-A clue of poor prognosis in primary non-metastatic breast cancer? Breast Cancer Research and Treatment, 73, 275-277. doi:10.1023/A:1015864322007

[581] von Tempelhoff, G.F., Nieman, F., Heilmann, L. and Hommel, G. (2000) Association between blood rheology, thrombosis and cancer survival in patients with gynecologic malignancy. Clinical Hemorheology and Microcirculation, 22, 107-130.

[582] Bradlow, H.L., Fishman, J. and Osborne M.P. (1997) Cancer: Genetics and the environment. Annals of the New York Academy of Sciences, 833, 209.

[583] Bhatia, S., Robison, L.L., Oberlin, O., Greenberg, M., Bunin, G., Fossati-Bellani, F. and Meadows, A.T. (1996) Breast cancer and other second neoplasms after childhood Hodgkin's disease. The New England Journal of Medicine, 334, 745-751. doi:10.1056/NEJM199603213341201

[584] Jee, S.H., Ohrr, H., Sull, J.W., Yun, J.E., Ji, M. and Samet, J.M. (2005) Fasting serum glucose level and cancer risk in Korean men and women. The Journal of the American Medical Association, 293, 194-202. doi:10.1001/jama.293.2.194

[585] Coussens, L.M. and Werb, Z. (2002) Inflammation and cancer. Nature, 420, 860-867. doi:10.1038/nature01322

[586] Elikowski, W., Maka, K., Bol, K., Jedlinski, I. and Kubaszewska, M. (2006) Multifocal ischaemic stroke and myocardial infarction in a woman with occult lung cancer complicated with chronic DIC and thrombotic endocarditis. Neurologia i Neurochirurgia Polska, 40, 530-535.

[587] Fitzgerald, R.H. Jr. (1979) Laboratory diagnosis of postoperative sepsis of the musculoskeletal system. Orthopedic Clinics of North America, 10, 361-374.

[588] McCoy, G.D. and Wynder, E.L. (1979) Etiological and preventive implications in alcohol carcinogenesis. Cancer Research, 39, 2844-2850.

[589] Pankhurst, T., Savage, C.O., Gordon, C. and Harper, L. (2004) Malignancy is increased in ANCA-associated vasculitis. Rheumatology (Oxford), 43, 1532-1535. doi:10.1093/rheumatology/keh374

[590] Sala-Serra, M., Sunyer, J., Kogevinas, M., McFarlane, D. and Anto, J.M. (1996) Cohort study on cancer mortality among workers in the pulp and paper industry in Catalo- 
nia, Spain. American Journal of Industrial Medicine, 30, 87-92. doi:10.1002/(SICI)1097-0274(199607)30:1<87::AID-AJI M15>3.0.CO;2-4

[591] Smedby, K.E., Baecklund, E. and Askling, J. (2006) Malignant lymphomas in autoimmunity and inflammation: A review of risks, risk factors, and lymphoma characteristics. Cancer Epidemiology, Biomarkers \& Prevention, 15, 2069-2077. doi:10.1158/1055-9965.EPI-06-0300

[592] Davis, D. (2007) The secret history of the war on cancer. Perseus Books Group, New York.

[593] Levi, M., van der Poll, T. and Cate, H.T. (2006) Tissue factor in infection and severe inflammation. Seminars in Thrombosis and Hemostasis, 32, 33-39. doi:10.1055/s-2006-933338

[594] Asanuma, K., Wakabayashi, H., Hayashi, T., Okuyama, N., Seto, M., Matsumine, A., Kusuzaki, K., Suzuki, K. and Uchida, A. (2004) Thrombin inhibitor, argatroban, prevents tumor cell migration and bone metastasis. Oncology, 67, 166-173. doi:10.1159/000081004

[595] Bobek, V. and Kovarik, J. (2004) Antitumor and antimetastatic effect of warfarin and heparins. Biomedicine \& Pharmacotherapy, 58, 213-219. doi:10.1016/j.biopha.2003.11.007

[596] Cao, Q.Z., Niu, G. and Tan, H.R. (2005) In vitro growth inhibition of human colonic tumor cells by Verapamil. World Journal of Gastroenterology, 11, 2255-2259.

[597] Holzheimer, R.G. (2004) Low-molecular-weight heparin (LMWH) in the treatment of thrombosis. European Journal of Medical Research, 9, 225-239.

[598] Hampton, K.K., Grant, P.J., Primrose, J., Dean, H.G., Davies, J.A. and Prentice, C.R. (1991) Haemostatic responses and vasopressin release during colonoscopy in man. Clinical Science (Lond), 81, 257-260.

[599] Samama, C.M., Thiry, D., Elalamy, I., Diaby, M., Guillosson, J.J., Kieffer, E. and Coriat, P. (2001) Perioperative activation of hemostasis in vascular surgery patients. Anesthesiology, 94, 74-78. doi:10.1097/00000542-200101000-00015

[600] Weissman, C. (1990) The metabolic response to stress: An overview and update. Anesthesiology, 73, 308-327. doi:10.1097/00000542-199008000-00020

[601] Monk, T.G., Saini, V., Weldon, B.C. and Sigl, J.C. (2005) Anesthetic management and one-year mortality after noncardiac surgery. Anesthesia \& Analgesia, 100, 4-10. doi:10.1213/01.ANE.0000147519.82841.5E

[602] Liberzon, I., Abelson, J.L., Amdur, R.L., King, A.P., Cardneau, J.D., Henke, P. and Graham, L.M. (2006) Increased psychiatric morbidity after abdominal aortic surgery: Risk factors for stress-related disorders. Journal of Vascular Surgery, 43, 929-934. doi:10.1016/j.jvs.2006.01.026

[603] Chernow, B., Alexander, H.R., Smallridge, R.C., Thompson, W.R., Cook, D., Beardsley, D., Fink, M.P., Lake, C.R. and Fletcher, J.R. (1987) Hormonal responses to graded surgical stress. Archives of Internal Medicine, 147, 1273-1278. doi:10.1001/archinte.1987.00370070087013
[604] Kavarana, M.N., Frumento, R.J., Hirsch, A.L., Oz, M.C., Lee, D.C. and Bennett-Guerrero, E. (2003) Gastric hypercarbia and adverse outcome after cardiac surgery. Intensive Care Medicine, 29, 742-758.

[605] McDaniel, M.D., Pearce, W.H., Yao, J.S., Rossi, E.C., Fahey, V.A., Green, D., Flinn, W.R. and Bergan, J.J. (1984) Sequential changes in coagulation and platelet function following femorotibial bypass. Journal of Vascular Surgery, 1, 261-268.

[606] Abram, S.E. and Yaksh, T.L. (1994) Systemic lidocaine blocks nerve injury-induced hyperalgesia and nociceptordriven spinal sensitization in the rat. Anesthesiology, 80, 383-391.

[607] Abram, S.E. and Yaksh, T.L. (1993) Morphine, but not inhalation anesthesia, blocks post-injury facilitation. The role of preemptive suppression of afferent transmission. Anesthesiology, 78, 713-721. doi:10.1097/00000542-199304000-00015

[608] Eliopoulos, A.G., Kerr, D.J., Herod, J.,Hodgkins, L., Krajewski, S., Reed, J.C. and Young, L.S. (1995) The control of apoptosis and drug resistance in ovarian cancer: Influence of p53 and Bcl-2. Oncogene, 11, 1217-1228.

[609] Crile G.W. and Lower, L.W. (1914) Anoci-association. Saunders, Philadelphia, 223-225.

[610] Schneemilch, C.E. and Bank, U. (2001) Release of proand anti-inflammatory cytokines during different anesthesia procedures. Anaesthesiologie und Reanimation, 26, 4-10.

[611] Ben-Shlomo, I., Finger, J., Bar-Av, E., Perl, A.Z., Etchin, A. and Tverskoy, M. (1993) Propofol and fentanyl act additively for induction of anaesthesia. Anaesthesia, 48, 111-113. doi:10.1111/j.1365-2044.1993.tb06846.x

[612] Ben-Shlomo, I., abd-el-Khalim, H., Ezry, J., Zohar, S. and Tverskoy, M. (1990) Midazolam acts synergistically with fentanyl for induction of anaesthesia. British Journal of Anaesthesia, 64, 45-47. doi:10.1093/bja/64.1.45

[613] Brunner, M.D., Braithwaite, P., Jhaveri, R., McEwan, A.I., Goodman, D.K., Smith, L.R. and Glass, P.S. (1994) MAC reduction of isoflurane by sufentanil. British Journal of Anaesthesia, 72, 42-46. doi:10.1093/bja/72.1.42

[614] Beattie, W.S., Badner, N.H. and Choi, P. (2001) Epidural analgesia reduces postoperative myocardial infarction: A meta-analysis. Anesthesia \& Analgesia, 93, 853-858. doi:10.1097/00000539-200110000-00010

[615] Von Dossow, V., Welte, M., Zaune, U., Martin, E., Walter, M., Ruckert, J., Kox, W.J. and Spies, C.D. (2001) Thoracic epidural anesthesia combined with general anesthesia: The preferred anesthetic technique for thoracic surgery. Anesthesia \& Analgesia, 92, 848-854. doi:10.1097/00000539-200104000-00010

[616] Vinik, H.R., Bradley, E.L. Jr. and Kissin, I. (1994) Triple anesthetic combination: Propofol-midazolam-alfentanil. Anesthesia \& Analgesia, 78, 354-358. doi:10.1213/00000539-199402000-00026

[617] Negishi, C., Kim, J.S., Lenhardt, R., Sessler, D.I., Ozaki, M., Vuong, K., Bastanmehr, H. and Bjorksten, A.R. (2000) Alfentanil reduces the febrile response to interleukin-2 in humans. Critical Care Medicine, 28, 1295-1300. 
doi:10.1097/00003246-200005000-00006

[618] Dubois, M., Pickar, D., Cohen, M., Gadde, P., Macnamara, T.E. and Bunney, W.E. (1982) Effects of fentanyl on the response of plasma beta-endorphin immunoreactivity to surgery. Anesthesiology, 57, 468-472. doi:10.1097/00000542-198212000-00006

[619] Glass, P. S., Gan, T. J., Howell, S. and Ginsberg, B. (1997) Drug interactions: Volatile anesthetics and opioids. Journal of Clinical Anesthesia, 9, 18S-22S. doi:10.1016/S0952-8180(97)00122-0

[620] Hecker, B.R., Lake, C.L., DiFazio, C.A., Moscicki, J.C. and Engle, J.S. (1983) The decrease of the minimum alveolar anesthetic concentration produced by sufentanil in rats. Anesthesia \& Analgesia, 62, 987-990. doi:10.1213/00000539-198311000-00005

[621] Klassen, G.A., Bramwell, R.S., Bromage, P.R. and Zborowska-Sluis, D.T. (1980) Effect of acute sympathectomy by epidural anesthesia on the canine coronary circulation. Anesthesiology, 52, 8-15. doi:10.1097/00000542-198001000-00003

[622] Kissin, I., Vinik, H.R., Castillo, R. and Bradley, E.L. Jr. (1990) Alfentanil potentiates midazolam-induced unconsciousness in subanalgesic doses. Anesthesia \& Analgesia, 71, 65-69. doi:10.1213/00000539-199007000-00011

[623] Mallinder, P.A., Hall, J.E., Bergin, F.G., Royle, P. and Leaper, D.J. (2000) A comparison of opiate- and epiduralinduced alterations in splanchnic blood flow using intraoperative gastric tonometry. Anaesthesia, 55, 659-665. doi:10.1046/j.1365-2044.2000.01475.x

[624] Steffey, E.P., Martucci, R., Howland, D., Asling, J.H. and Eisele, J.H. (1977) Meperidine-halothane interaction in dogs. Canadian Journal of Anesthesia, 24, 459-467. doi:10.1007/BF03005450

[625] Pypendop, B.H. and Ilkiw, J.E. (2005) The effects of intravenous lidocaine administration on the minimum alveolar concentration of isoflurane in cats. Anesthesia \& Analgesia, 100, 97-101. doi:10.1213/01.ANE.0000139350.88158.38

[626] Rakaric-Poznanovic, M., Ranic, V. and Snur, I. (1995) Multiorgan dysfunction syndrome (MODS) caused by long bone fractures in young persons. Lijecnicki Vjesnik, 117, 85-87.

[627] Valverde, A., Doherty, T.J., Hernandez, J. and Davies, W. (2004) Effect of lidocaine on the minimum alveolar concentration of isoflurane in dogs. Veterinary Anaesthesia and Analgesia, 31, 264-271. doi:10.1111/j.1467-2995.2004.00165.X

[628] Zhang, Y., Laster, M.J., Eger, E.I., 2nd, Sharma, M. and Sonner, J.M. (2007) Lidocaine, MK-801, and MAC. Anesthesia \& Analgesia, 104, 1098-1102. doi:10.1213/01.ane.0000260318.60504.a9

[629] Hall, R.I., Szlam, F. and Hug, C.C. Jr. (1987) The enflurane-sparing effect of alfentanil in dogs. Anesthesia \& Analgesia, 66, 1287-1291. doi:10.1213/00000539-198712000-00015

[630] Haldemann, G., Hossli, G. and Schaer, H. (1977) Anaesthesia with flunitrazepam (rohypnol) and fentanyl for geriatric patients (author's transl). Anaesthesist, 26, 168-
171.

[631] Kabon, B., Fleischmann, E., Treschan, T., Taguchi, A., Kapral, S. and Kurz, A. (2003) Thoracic epidural anesthesia increases tissue oxygenation during major abdominal surgery. Anesthesia \& Analgesia, 97, 1812-1817. doi:10.1213/01.ANE.0000087040.48267.54

[632] Kapral, S., Gollmann, G., Bachmann, D., Prohaska, B., Likar, R., Jandrasits, O., Weinstabl, C. and Lehofer, F. (1999) The effects of thoracic epidural anesthesia on intraoperative visceral perfusion and metabolism. Anesthesia \& Analgesia, 88, 402-406.

[633] Kehlet, H. and Holte, K. (2001) Effect of postoperative analgesia on surgical outcome. British Journal of Anaesthesia, 87, 62-72. doi:10.1093/bja/87.1.62

[634] Kono, K., Philbin, D.M., Coggins, C.H., Moss, J., Rosow, C.E., Schneider, R.C. and Slater, E.E. (1981) Renal function and stress response during halothane or fentanyl anesthesia. Anesthesia \& Analgesia, 60, 552-556. doi:10.1213/00000539-198108000-00003

[635] Lee, T.W., Grocott, H.P., Schwinn, D. and Jacobsohn, E. (2003) High spinal anesthesia for cardiac surgery: Effects on beta-adrenergic receptor function, stress response, and hemodynamics. Anesthesiology, 98, 499-510. doi:10.1097/00000542-200302000-00032

[636] Lessa, M.A. and Tibirica, E. (2006) Pharmacologic evidence for the involvement of central and peripheral opioid receptors in the cardioprotective effects of fentanyl. Anesthesia \& Analgesia, 103, 815-821. doi:10.1213/01.ane.0000237284.30817.f6

[637] Lessa, M.A., Rodrigues, E. and Tibirica, E. (2004) Cardioprotective action of fentanyl in a model of central sympathetic overactivity in rabbits: Antiarrhythmic and anti-ischemic effects. Acta Anaesthesiologica Scandinavica, 48, 1115-1122. doi:10.1111/j.1399-6576.2004.00472.x

[638] McEwan, A.I., Smith, C., Dyar, O., Goodman, D., Smith, L.R. and Glass, P.S. (1993) Isoflurane minimum alveolar concentration reduction by fentanyl. Anesthesiology, 78, 864-869. doi:10.1097/00000542-199305000-00009

[639] Moffitt, E.A., McIntyre, A.J., Barker, R.A., Imrie, D. D., Murphy, D.A., Landymore, R.W. and Kinley, C.E. (1986) Myocardial metabolism and hemodynamic responses with fentanyl-enflurane anesthesia for coronary arterial surgery. Anesthesia \& Analgesia, 65, 46-52.

[640] Murphy, M.R. and Hug, C.C. Jr. (1982) The anesthetic potency of fentanyl in terms of its reduction of enflurane MAC. Anesthesiology, 57, 485-488. doi:10.1097/00000542-198212000-00009

[641] O’Connor, T.C. and Abram, S.E. (1994) Halothane enhances suppression of spinal sensitization by intrathecal morphine in the rat formalin test. Anesthesiology, 81, 1277-1283. doi:10.1097/00000542-199411000-00023

[642] Sinatra, R.S., Hord, A.H., Ginsburg, B. and Preble, L. (1972) Acute pain: Mechanisms and management. Mosby Year-Book, Inc., St. Louis, 49

[643] Rowlingson, J.C. (2006) In update on acute pain management, 80th clinical and scientific congress of the international anesthesia research society, Embarcadero 
Center, San Francisco, International Anesthesia Research Society, Embarcadero Center, San Francisco, 137.

[644] Shavit, Y., Ben-Eliyahu, S., Zeidel, A. and Beilin, B. (2004) Effects of fentanyl on natural killer cell activity and on resistance to tumor metastasis in rats. Dose and timing study. Neuroimmunomodulation, 11, 255-260. doi:10.1159/000078444

[645] Skarvan, K. and Schwinn, W. (1986) Hemodynamic interaction between midazolam and alfentanil in coronary patients. Anaesthesist, 35, 17-23.

[646] Stefano, G.B., Scharrer, B., Smith, E.M., Hughes, T.K., Jr., Magazine, H.I., Bilfinger, T.V., Hartman, A.R., Fricchione, G.L., Liu, Y. and Makman, M.H. (1996) Opioid and opiate immunoregulatory processes. Critical Reviews $^{\mathrm{TM}}$ in Immunology, 16, 109-144. doi:10.1615/CritRevImmunol.v16.i2.10

[647] Stefano, G.B., Rodriguez, M., Glass, R., Cesares, F., Hughes, T.K. and Bilfinger, T.V. (1995) Hyperstimulation of leukocytes by plasma from cardiopulmonary by-pass patients is diminished by morphine and IL-10 pretreatment. Journal of Cardiothoracic Surgery (Torino), 36, 25-30.

[648] Vermeyen, K.M., Erpels, F.A., Beeckman, C.P., Janssen, L.A. and Adriaensen, H.F. (1989) Low-dose sufentanilisoflurane anaesthesia for coronary artery surgery. British Journal of Anaesthesia, 63, 44-50. doi:10.1093/bja/63.1.44

[649] Goto, A., Kadowaki, T. and Kitagawa, Y. (2003) Drosophila hemolectin gene is expressed in embryonic and larval hemocytes and its knock down causes bleeding defects. Developmental Biology, 264, 582-591. doi:10.1016/j.ydbio.2003.06.001

[650] Anim-Nyame, N., Gamble, J., Sooranna, S.R., Johnson, M.R., Sullivan, M.H. and Steer, P.J. (2003) Evidence of impaired microvascular function in pre-eclampsia: A noninvasive study. Clinical Science (Lond), 104, 405-412. doi:10.1042/CS20020323

[651] Bryson, C.L., Ioannou, G.N., Rulyak, S.J. and Critchlow, C. (2003) Association between gestational diabetes and pregnancy-induced hypertension. American Journal of Epidemiology, 158, 1148-1153. doi:10.1093/aje/kwg273

[652] Harskamp, R.E. and Zeeman, G.G. (2007) Preeclampsia: At risk for remote cardiovascular disease. The American Journal of the Medical Sciences, 334, 291-295. doi:10.1097/MAJ.0b013e3180a6f094

[653] Inglis, T.C., Stuart, J., George, A.J. and Davies, A.J. (1982) Haemostatic and rheological changes in normal pregnancy and pre-eclampsia. British Journal of Haematology, 50, 461-465. doi:10.1111/j.1365-2141.1982.tb01941.x

[654] Kabon, B., Nagele, A., Reddy, D., Eagon, C., Fleshman, J. W., Sessler, D.I. and Kurz, A. (2004) Obesity decreases perioperative tissue oxygenation. Anesthesiology, 100, 274-280. doi:10.1097/00000542-200402000-00015

[655] Ogawa, T., Suzuki, Y., Sayama, S. and Soma, H. (1983) Possible relationship between the ratio of Factor VIII complex and placental insufficiency in preeclampsia. Biological Research in Pregnancy and Perinatology, 4,
155-157.

[656] Roy, K.K., Malhotra, N. and Banerjee, K. (2001) Recurrent eclampsia in a woman with chronic pyelonephritis. European Journal of Obstetrics \& Gynecology and Reproductive Biology, 94, 307-308. doi:10.1016/S0301-2115(00)00343-2

[657] Scholtes, M.C., Gerretsen, G. and Haak, H.L. (1983) The factor VIII ratio in normal and pathological pregnancies. European Journal of Obstetrics \& Gynecology and Reproductive Biology, 16, 89-95. doi:10.1016/0028-2243(83)90105-3

[658] Thornton, C.A. and Bonnar, J. (1977) Factor VIII-related antigen and factor VIII coagulant activity in normal and pre-eclamptic pregnancy. British Journal of Obstetrics and Gynaecology, 84, 919-923. doi:10.1111/j.1471-0528.1977.tb12521.x

[659] Weiner, C.P. and Brandt, J. (1982) Plasma antithrombin III activity: An aid in the diagnosis of preeclampsiaeclampsia. American Journal of Obstetrics \& Gynecology, 142, 275-281.

[660] Khatun, S., Kanayama, N., Belayet, H.M., Tokunaga, N., Sumimoto, K., Kobayashi, T. and Terao, T. (1999) Induction of hypercoagulability condition by chronic localized cold stress in rabbits. Journal of Thrombosis and Haemostasis, 81, 449-455.

[661] Newman, M.G., Lindsay, M.K. and Graves, W. (2001) Cigarette smoking and pre-eclampsia: Their association and effects on clinical outcomes. The Journal of Maternal-Fetal Medicine, 10, 166-170. doi:10.1080/jmf.10.3.166.170

[662] Frank, J.M. and Palomino, N.J. (1987) Primary amyloidosis with diffuse splenic infiltration presenting as fulminant pneumococcal sepsis. American Journal of Clinical Pathology, 87, 405-407.

[663] Angelov, A. (1989) Intracranial venous thrombosis in relation to pregnancy and delivery. Pathology-Research and Practice, 185, 843-847. doi:10.1016/S0344-0338(89)80284-5

[664] Angelov, A. (1989) Intravascular coagulation in relation to pregnancy and delivery. Zentralblatt fur Gynakologie, 111, 1169-1175.

[665] Bruhn, H.D., Bernsmeier, R., Luck, P., Zurborn, K.H. and Christophers, E. (1983) Influences of thrombin, factor XIII and fibronectin on the growth of tumor cells and leukemic cells in vitro. Journal of Molecular Medicine, 61, 209-211. doi:10.1007/BF01488977

[666] Darmoul, D., Gratio, V., Devaud, H., Lehy, T. and Laburthe, M. (2003) Aberrant expression and activation of the thrombin receptor protease-activated receptor-1 induces cell proliferation and motility in human colon cancer cells. American Journal of Pathology, 162, 1503-1513. doi:10.1016/S0002-9440(10)64283-6

[667] De Vos, J., Couderc, G., Tarte, K., Jourdan, M., Requirand, G., Delteil, M.C., Rossi, J.F., Mechti, N. and Klein, B. (2001) Identifying intercellular signaling genes expressed in malignant plasma cells by using complementary DNA arrays. Blood, 98, 771-780. doi:10.1182/blood.V98.3.771

[668] Dvorak, H.F. (1986) Tumors: Wounds that do not heal. 
Similarities between tumor stroma generation and wound healing. The New England Journal of Medicine, 315, 1650-1659.

[669] Farber, E. (1995) Cell proliferation as a major risk factor for cancer: A concept of doubtful validity. Cancer Research, 55, 3759-3762.

[670] Klementsen, B. and Jorgensen, L. (1997) Mechanisms involved in the early interaction between HeLa cells, platelets and endothelial cells in vitro under the influence of thrombin. Effects of acetylsalicylic acid and Na-Salicylate. APMIS: Acta Pathologica, Microbiologica et Immunologica Scandinavica, 105, 391-401. doi:10.1111/j.1699-0463.1997.tb00586.x

[671] Poste, G. and Greig, R. (1982) On the genesis and regulation of cellular heterogeneity in malignant tumors. Invasion Metastasis, 2, 137-176.

[672] Sporn, M.B. (1991) Carcinogenesis and cancer: Different perspectives on the same disease. Cancer Research, 51, 6215-6218.

[673] Versteeg, H.H., Spek, C.A., Richel, D.J. and Peppelenbosch, M.P. (2004) Coagulation factors VIIa and Xa inhibit apoptosis and anoikis. Oncogene, 23, 410-417. doi:10.1038/sj.onc.1207066

[674] Jin, E., Fujiwara, M., Pan, X., Ghazizadeh, M., Arai, S., Ohaki, Y., Kajiwara, K., Takemura, T. and Kawanami, O. (2003) Protease-activated receptor (PAR)-1 and PAR-2 participate in the cell growth of alveolar capillary endothelium in primary lung adenocarcinomas. Cancer, 97, 703-713. doi:10.1002/cncr.11087

[675] Orbach, H., Zandman-Goddard, G., Amital, H., Barak, V., Szekanecz, Z., Szucs, G., Danko, K., Nagy, E., Csepany, T., Carvalho, J.F., Doria, A. and Shoenfeld, Y. (2007) Novel biomarkers in autoimmune diseases: Prolactin, ferritin, vitamin D, and TPA levels in autoimmune diseases. Annals of the New York Academy of Sciences, 1109, 385400. doi:10.1196/annals.1398.044

[676] Lind, S.E., Smith, D.B., Janmey, P.A. and Stossel, T.P. (1988) Depression of gelsolin levels and detection of gelsolin-actin complexes in plasma of patients with acute lung injury. American Review of Respiratory Disease, 138, 429-434.

[677] Lind, S.E. and Janmey, P.A. (1984) Human plasma gelsolin binds to fibronectin. The Journal of Biological Chemistry, 259, 13262-13266.

[678] Lind, S.E., Smith, D.B., Janmey, P.A. and Stossel, T.P. (1986) Role of plasma gelsolin and the vitamin D-binding protein in clearing actin from the circulation. Journal of Clinical Investigation, 78, 736-742. doi:10.1172/JCI112634

[679] Janmey, P.A., Lind, S.E., Yin, H.L. and Stossel, T.P. (1985) Effects of semi-dilute actin solutions on the mobility of fibrin protofibrils during clot formation. Biochimica et Biophysica Acta, 841, 151-158. doi:10.1016/0304-4165(85)90016-9

[680] Wada, H., Wakita, Y., Nakase, T., Shimura, M., Hiyoyama, K., Nagaya, S., Deguchi, H., Mori, Y., Kaneko, T., Deguchi, K., Fujii, J. and Shiku, H. (1996) Increased plasma-soluble fibrin monomer levels in patients with disseminated intravascular coagulation. American Journal of Hematology, 51, 255-260. doi:10.1002/(SICI)1096-8652(199604)51:4<255::AID-AJ H1>3.0.CO;2-V

[681] Wada, H., Sase, T., Matsumoto, T., Kushiya, F., Sakakura, M., Mori, Y., Nishikawa, M., Ohnishi, K., Nakatani, K., Gabazza, E.C., Shiku, H. and Nobori, T. (2003) Increased soluble fibrin in plasma of patients with disseminated intravascular coagulation. Clinical and Applied Thrombosis/Hemostasis, 9, 233-240. doi: $10.1177 / 107602960300900308$

[682] Bowie, E.J. and Owen, C.A. (1983) The clinical pathology of intravascular coagulation. Bibliotheca haematologica, 217-224.

[683] Hardaway, R.M., Chun, B. and Rutherford, R.B. (1965) Histologic evidence of disseminated intravascular coagulation in clinical shock. Vascular Disease, 2, 254-265.

[684] Hardy, J.F., de Moerloose, P. and Samama, C.M. (2005) The coagulopathy of massive transfusion. Vox Sanguinis, 89, 123-127. doi:10.1111/j.1423-0410.2005.00678.x

[685] Singh, M.V., Salhan, A.K., Rawal, S.B., Tyagi, A.K., Kumar, N., Verma, S.S. and Selvamurthy, W. (2003) Blood gases, hematology, and renal blood flow during prolonged mountain sojourns at 3500 and $5800 \mathrm{~m}$. Aviation, Space, and Environmental Medicine, 74, 533-536.

[686] Suzuki, S. and Morishita, S. (1998) Hypercoagulability and DIC in high-risk infants. Seminars in Thrombosis and Hemostasis, 24, 463-466.

doi:10.1055/s-2007-996040

[687] Ruttmann, T.G., Montoya-Pelaez, L.F. and James, M.F. (2007) The coagulation changes induced by rapid in vivo crystalloid infusion are attenuated when magnesium is kept at the upper limit of normal. Anesthesia \& Analgesia, 104, 1475-1480. doi:10.1213/01.ane.0000261256.88414.e4

[688] Chappell, D., Jacob, M., Hofmann-Kiefer, K., Conzen, P. and Rehm, M. (2008) A rational approach to perioperative fluid management. Anesthesiology, 109, 723-740. doi:10.1097/ALN.0b013e3181863117

[689] Lane, N. (2005) Power, sex, suicide mitochondria and the meaning of life. Oxford University Press, New York, 346.

[690] Mattick, J.S. (2004) The regulatory architecture of the human genome. Asia Pacific Journal of Clinical Nutrition, 13, S14.

[691] Mattick, J.S. (2004) The hidden genetic program of complex organisms. Scientific American, 291, 60-67. doi:10.1038/scientificamerican1004-60

[692] Mattick, J.S. (2003) Challenging the dogma: The hidden layer of non-protein-coding RNAs in complex organisms. Bioessays, 25, 930-939. doi:10.1002/bies.10332

[693] Kirschner, M.W. and Gerhart, J.C. (2005) The plausibility of life: Resolving darwin's dilemma. Vail-Ballou Press, Binghamton.

[694] Johnson, M.H. and Day, M.L. (2000) Egg timers: How is developmental time measured in the early vertebrate embryo? Bioessays, 22, 57-63. doi:10.1002/(SICI)1521-1878(200001)22:1<57::AID-BIE $\underline{\mathrm{S} 10>3.0 . \mathrm{CO} ; 2-\mathrm{L}}$ 
[695] Pontin, J. (2010) A decade of genomics. Technology Review, 1.

[696] Gibbs, W.W. (2003) Untangling the roots of cancer. Scientific American, 289, 56-65. doi:10.1038/scientificamerican0703-56

[697] Kuhn, T.S. (1996) The structure of scientific revolutions. University of Chicago Press, Chicago. 